BROWN
JUDAIC
STUDIES

\title{
A History of the \\ United Jewish Appeal \\ 1939-1982
}

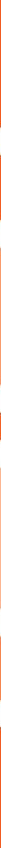

Marc Lee Raphael 
A HISTORY OF THE UNITED JEWISH APPEAL 1939-1982 


\title{
BROWN UNIVERSITY
}

\author{
BROWN JUDAIC STUDIES \\ Edited by \\ Jacob Neusner
}

Wendell S. Dietrich, Ernest S. Frerichs, Alan Zuckerman

Board of Editors

David Altshuler, George Washington University

David R. Blumenthal, Emory University

Baruch M. Bokser, University of California, Berkeley

Joel Gereboff, Arizona State University

David Goldenberg, Dropsie University

Robert Goldenberg, State University of New York, Stony Brook

David Goodblatt, Haifa University

William Scott Green, University of Rochester

Peter Haas, Vanderbilt University

Martin Jaffee, University of Virginia

Shamai Kanter, Temple Beth El, Rochester, New York

Jack L. Lightstone, Concordia University

Irving Mandelbaum, University of Texas

Alan Mintz, University of Maryland

Alan J. Peck, Tulane University

Gary G. Porton, University of Illinois

Marc L. Raphael, Ohio State University

Richard S. Sarason, Hebrew Union College-Jewish Institute of Religion

Tzvee Zahavy, University of Minnesota

Editorial Committee:

Roger Brooks

Louis Newman

\section{Number 34}

A HISTORY OF THE UNITED JEWISH APPEAL

1939-1982

by Marc Lee Raphael 
A HISTORY OF THE UNITED JEWISH APPEAL

1939-1982

by

Marc Lee Raphael

Scholars Press 


\section{A HISTORY OF THE UNITED JEWISH APPEAL 1839-1982 \\ by \\ Marc Lee Raphael}

Copyright @ 2020 by Brown University

Library of Congress Control Number: 2019953438

Publication of this book is made possible, in part, by Mr. Lyman Bloomingdale and by The Max Richter Foundation of Rhode Island.

Open access edition funded by the National Endowment for the Humanities/Andrew W. Mellon Foundation Humanities Open Book Program.

The text of this book is licensed under a Creative Commons Attribution-NonCommercialNoDerivatives 4.0 International License: https://creativecommons.org/licenses/by-nc-nd/4.0/. To use this book, or parts of this book, in any way not covered by the license, please contact Brown Judaic Studies, Brown University, Box 1826, Providence, RI 02912. 
For Gary Reichard colleague, scholar, and friend 



\section{ACKNOWLEDGEMENTS}

The idea for a history of the United Jewish Appeal was first suggested to me on 9 september 1977, in New York City, by Moshe Davis (Hebrew University) and Henry Feingold (CUNY). subsequently, my research was aided by Evyatar Friesel (Jerusalem), Col. S. J. Pomrenze (New York), Henry Montor (Rome), Al Rosen (Boston), Herbert Friedman (New York), and Nathan Kaganoff (Waltham), as well as by a Small Research Grant from The Ohio State University Graduate School and a grant from the American Philosophical society. Early encouragement came from Amnon Hadary (Jerusalem), who published a slightly different version of Chapter 2 in Forum, and continual support was provided by Stephen Whitfield (Brandeis University), Stanley Chyet (Hebrew Union College), and Jacob Neusner (Brown University).

I wish to especially acknowledge the scholarly and collegial support of Gary Reichard, chairman of the osu history department. (1977-1981) during the research and writing of this volume. His commitment to the project made my overseas and out-of-state travel possible, and he worked hard to provide me the environment so necessary for productive scholarship.

Finally, a technical matter. All archival material not specifically cited from the Central zionist Archives (Jerusalem), the American Jewish Historical Society (Waltham), the Combined Jewish Philanthropies (Boston), or the Columbus Jewish Federation is to be found in the United Jewish Appeal archives (New York). 

TABLE OF CONTENTS

ACKNOWLEDGEMENTS . . . . . . . . . . . . . . . . vii CHAPTERS

1. FROM SEPARATISM TO COMMUNITY: THE ORIGINS OF THE UNITED JEWISH APPEAL . . . . . . . . . 1

2. THE WAR YEARS: 1939-1945........... 13

3. THE FIRST $\$ 100,000,000$ CAMPAIGN: 1946 .... 21

4. AMERICAN JEWRY'S CAMPAIGN OF SACRIFICE: 1947 AND CAMPAIGN OF DESTINY: 1948: . . . . . . . . . . . . . 29

5. HENRY MONTOR'S FINAL TWO CAMPAIGNS: 1949-1950 AND THE JOSEPH H. SCHWARTZ YEARS : $1951-1955$. . . . . . . . . . 39

6. THE "BIG GIVER" . . . . . . . . . . . 47

7. THE VIEW FROM THE TOP: HERBERT FRIEDMAN'S REIGN: 1956-1969 ....... . 63

8. THE AMERICAN JEWISH PHILANTHROPIC RESPONSE TO THE SIX DAY AND YOM KIPPUR WARS

a. COLUMBUS, OHIO--MAY/JUNE 1967:

A CASE STUDY . . . . . . . . . . 77

b. BOSTON, MASS.--OCTOBER 1.973:

A CASE STUdY . . . . . . . . . . . 81

9. The "MANagement team:" the increased

ROLE OF LAY LEADERS AND PROFESSIONAL STAFF IN THE l970s ............ 85 
10. PROJECT RENEWAL ................... 101

11. PROBLEMS AND PROSPECTS ............ 111 NOTES . . . . . . . . . . . . . . . . 117 LIST OF TABLES . . . . . . . . . . . . . 135 TABLES . . . . . . . . . . . . . . . . 136

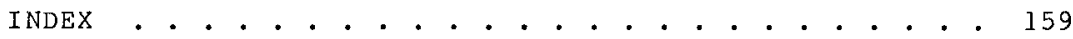




\section{PUBLISHERS' PREFACE}

Brown Judaic Studies has been publishing scholarly books in all areas of Judaic studies for forty years. Our books, many of which contain groundbreaking scholarship, were typically printed in small runs and are not easily accessible outside of major research libraries. We are delighted that with the support of a grant from the National Endowment for the Humanities/Andrew W. Mellon Foundation Humanities Open Book Program, we are now able to make available, in digital, open-access, format, fifty titles from our backlist.

We are pleased to be able to reissue Marc Lee Raphael's, A History of the United Jewish Appeal, 1939-1982 (1982). The United Jewish Appeal was the major Jewish philanthropic umbrella organization in the United States until it was folded into a successor organization in 1999. Drawing on original archival research, Raphael's book charts the boon years of the organization.

This edition contains some corrections of the original text.

Michael L. Satlow Managing Editor October, 2019 

CHAPTER 1

FROM SEPARATISM TO COMMUNITY:

THE ORIGINS OF THE UNITED JEWISH APPEAL

The United Jewish Appeal is a voluntary organization of American Jewry specializing in the collection of funds. Well known in the United states, even outside of Jewish circles, its fame extends beyond America and is by no means limited to the State of Israel, its principal beneficiary. From modest beginnings before and during world war II, when annual drives produced $\$ 15,000,000$ or $\$ 20,000,000$, the UJA had succeeded, by the mid-seventies, in coordinating the raising of nearly a half-billion dollars.

On 10 January 1939 three American Jewish leaders met in New York and signed a document creating the "reconstituted" UJA. The three signatories were Rabbi Jonah B. Wise (1881-1959), Rabbi Abba Hillel Silver (1893-1963), and William Rosenwald (b. 1903). They represented, respectively, two competing organizations with opposing purposes: the American Jewish Joint Distribution Committee (JDC) and the United Palestine Appeal (UPA), as well as a beneficiary agency established in 1938, the National Coordinating Committee for Aid to Refugees and Emigrants Coming from Germany (NCCR). This agreement made the UJA the single American Jewish fundraising organization for the work of relief and rehabilitation in Europe, for immigration and settlement in palestine, and for refugee aid in the United states. And despite the complexities of priorities and allocations, this 1939 agreement has functioned continuously (except for part of one year, 1941) ever since. ${ }^{1}$

The JDC, one of the two UJA "partners," was founded in 1914 to meet "overseas" needs; those of the small Jewish settlement in Palestine and those of the Jews of east Europe, as their homelands were transformed into battlegrounds by World war I. The leaders of the JDC opposed the claim of the zionists that Palestine provided the only solution to the Jewish problem. The Joint's philosophy consisted in giving aid to all Jews--wherever they might be--including those in palestine and those in countries both friendly and hostile to the United states. The JDC also funded diverse projects in many lands which promised to aid Jews; these included medical stations, loan cooperatives, 
vocational training schools, and agricultural settlements. This philosophy of the JDC was supported by the explicit optimism that Jewish life in Europe, despite the hardships of the twenties and thirties, would not only merely endure, but regain vitality. Such optimism enabled the Joint to raise and distribute hundreds of millions of dollars; but it, together with the implicit non-zionism of some of its leaders, also accounted for the clashes with the zionist organizations. ${ }^{2}$

The United Palestine Appeal, on the other hand, was focused exclusively upon zionism. Created in 1925 at the urging of American zionist leaders who wished to coordinate previously independent fundraising efforts in America devoted to the upbuilding of Jewish life in Palestine (especially those of the Jewish National Fund, the Palestine Foundation Fund, Mizrachi, and Hadassah), it was also a response to the launching of the ambitious fundraising campaign by the JDC. The latter sought to provide funds, jointly with the soviet government, to establish thousands of Soviet Jewish families in agricultural enterprises in the Crimean region; eventually, the Joint hoped, 250,000 Jews would occupy $3,000,000$ acres of land in colonies in the Ukraine and Crimea. In response to this and other Joint efforts, the zionists waged prolonged campaigns, throughout the twenties and thirties, to demonstrate that support for palestine was a more worthwhile investment than a diaspora agricultural settlement, to increase the proportion given to palestine from the welfare fund drives conducted in most cities, and to convince communities, whenever possible, to combine JDC and UPA drives and increase the latter's take. The zionists, generally speaking, met steady opposition from the controlling oligarchy of large. givers who generally favored European relief and distrusted zionist projects. ${ }^{3}$

After several years of bitter and tough negotiations between American Jewish and world zionist organization leaders in New York, an "enlarged" Jewish Agency was created in August of 1929 , according to the provisions of Article 4 of the British Mandate. It, for the first time, associated non-zionists with the efforts to build a Jewish National Home in Palestine by granting them 50 percent representation on the 224 -member plenary council as well as on the smaller administrative committee and even executive committee, and softened somewhat the rivalry between these two ideological positions. Indeed, a sign of the emerging cooperative spirit was the appointment of 
David Brown (1875-1958), a leader of several JDC campaigns, to head the palestine Emergency Fund campaign in the autumn of 1929.

Since the Joint Distribition Committee leadership consisted of men who sat as members of the Jewish Agency's non-zionist wing ( 40 percent of the non-zionists were to be Americans), the enlargement provided, as Chaim weizmann had hoped when he first proposed the partnership in 1923, the stimulus for several joint fundraising campaigns between the JDC and UPA. These nationwide campaigns took place in 1930 (Allied Jewish Campaign), 1934, and 1935 (United Jewish Appeal campaigns). ${ }^{4}$

Both attempts at cooperation, the political and philanthropic, collapsed. The experieice of the enlarged Jewish Agency was a failure, for the thrust of the zionist ideology came more and more to be directed toward a sovereign state, whereas the non-zionists, who opposed this, had joined only to provide cultural, scientific, and philanthropic support and, with America virtually closed, a land of refuge for east European Jews. Within a decade the non-zionists had ceased to participate, dropping out one by one as zionist domination overwhelmed the non-zionists despite the parity principle. ${ }^{5}$

Worse, only modest sums were collected in the joint appeals (the result of the expanded financial capacity and needs of the Jewish Agency and the joint campaigns coinciding with the Great Depression's depths). On 19 January 1930, after lengthy negotiations which began in May of 1928, Felix M. Warburg (1871-1937), chairman of the JDC and chairman of the Jewish Agency's administrative committee, announced that the JDC and Jewish Agency for Palestine (the latter representing the UPA) would soon launch a $\$ 6,000,000$ combined campaign for 1930. The funds would be split by allotting, to the delight of the Zionists, $\$ 3,500,000$ to the JDC and $\$ 2,500,000$ to the Jewish Agency, and would, Warburg hoped, "blend the effort of our people in eastern Europe and the promotion of the program of the Jewish Agency for Palestine," and "bring about. . . a measure of harmony and cooperation. ${ }^{6}$

Two months later 700 Jewish leaders, from communities across America, gathered in Washington to review the quota assigned to each city and to launch, over the NBC radio network, the Allied Jewish Campaign. Harmony and cooperation abounded; the Yiddish, Zionist, and Anglo-Jewish press saluted the agreement and denied any rivalry between the zionists and non-zionists. Louis Lipsky (1876-1963), president of the zionist organization of America, 
dramatically cemented the campaign bond (and made some zionist leaders shudder) by declaring that the "zionist movement aims not only to redeem Palestine for the Jews but also to strengthen Jewish life wherever possible." 7

The results of the Allied Jewish Campaign, despite the vigorous leadership of David Bressler (1879-1942), were extremely disappointing, and, with the zionists and non-zionists each blaming the other, the organizations launched independent campaigns in 1931, 1932, and 1933. The "lasting and permanent unity in American Israel," which warburg had envisioned, was abruptly terminated. ${ }^{8}$

In March of 1934, "in response to requests from leaders in certain communities urging the necessity for . . unified national fundraising," Louis Lipsky of the UPA and Morris Rothenberg (1885-1950) of the JDC launched the \$3,200,000 United Jewish Appeal. In the spring and summer alone, 300 campaigns got underway in American communities, including a $\$ 200,000$ campaign in Boston, another in Detroit for $\$ 175,000$, and a $\$ 108,900$ campaign in St. Louis (each to provide 45 percent of its total to the UJA), and, with a "Night of stars" at Yankee Stadium, the UJA launched a New York campaign, for $\$ 1,200,000$, exclusively for itself. The JDC received, by pre-arrangement, 55 percent of the national total, but its $\$ 1,290,000$ (of the mere $\$ 2,200,000$ ) was much smaller than its leaders felt they could raise independently. 9

Nevertheless, they agreed to support the UJA for another year. In 1935, however, of all the large cities, only cleveland met its quota and merely $\$ 1,600,000$ (albeit from 700 communities) was raised. This was $\$ 2,000,000$ less than the individual organizations had raised in 1928, and it came as no surprise then that, with strong pressure from the JDC leadership to get out, the executive committee of the UJA voted in october of 1935 to discontinue the joint campaign trial of 1934 and 1935.10

It was, of course, common practice prior to the 1930 s for individual charitable organizations to merge their fundraising activities. The United Fund or Community Chests and many Federations of Jewish Philanthropies were well-known examples. There were obvious reasons for such mergers. By having a common fund drive, the combined organizations saved considerable expenditure of resources which otherwise would have been largely duplicative; moreover, prospective donors were saved the annoyance of having more than one solicitor call. For both 
reasons, the net receipts of the combined charities (under similar economic conditions) may well go up. 11

on the other hand, such charitable combinations imposed a hidden cost on their donors. Whereas before the merger a donor could control the separate amounts which he or she gave to each charity, after the merger one could only control the total amount of his or her gift. The allocation of that total would generally be decided by the merged organization, and if the donor cared about that allocation he or she might be less well off than before. This was precisely the case with many of the richer elements in American Jewry, i.e. JDC donors after the merger, for they noted that, as a result of prearranged percentages, only 55 cents of every dollar now went to the Joint causes. The result was that these donors applied pressure on the JDC to resume independent fundraising. 12

The JDC executive committee noted that the "sums raised have not shown an increase commensurate with the great need, nor did they measure up to what was expected of American Jewry. . . " and blamed the "Palestine component" in the drive. An independent campaign would also leave the non-zionists "free to intensify their special appeals and enlist in their particular efforts additional supporters," i.e. non-zionists. The JDC made explicit this trend by announcing in April 1936, that it would not allot any money for palestine because of the unbearable burdens in Europe, and it would launch an independent fundraising camapaign for 1936. The zionists quickly followed suit, in order "to win the support of persons whose sympathies lay with one organization but not with both."13

Nevertheless, despite the failure of the first UJA, the zionists had accomplished a significant feat. The rebuilding of the Jewish homeland in Palestine was now accepted, by virtually the entire leadership of western Jewry, as a joint and noncontroversial responsibility of $\mathrm{zionist}$ and non-zionist alike. This would make far larger sums easier to collect a few years later.

The return to independent campaigns in 1936, 1937, and 1938 by both groups was to be short-lived. ${ }^{14}$ The immediate catalyst for the creation of the "new" United Jewish Appeal was the infamous Kristallnacht of 10 November 1938, and the decision of Göring to demand of Germany's Jews an "indemnity" of more than seven billion marks. This event literally crystallized the growing realization by the leaders of American Jewry that, in 
spite of their ideological differences, only a centralized and harmonious fundraising body could fully mobilize the vast resources needed to meet the crisis confronting the Jews of Europe on the eve of World War II.

Furthermore, as the number of refugees arriving in palestine began to dwindle steadily in 1937 and 1938 as a result of British restrictions, the JDC and UPA had a common goal: opening the doors of nations to Jewish refugees. The Joint reluctantly agreed to work for opening Palestine (it claimed its "big givers" would not give if the JDC joined with the UPA), while the zionists reluctantly understood the need to find other havens of refuge for Europe's Jews besides Palestine (the UPA claimed the JDC "ministers to the pathological phobias of a few New York Jews"). This common objective tenuously drew the organizations together, although the needs of a starved and terrorized European Jewry and the needs of Palestine Jewry remained foremost on the agendas of the JDC and UPA respectively. 15

Behind the drive for a united appeal stood the Council of Jewish Federations and Welfare Funds (CJFWF), the organization which united all the various Jewish communal federations and fundraising groups throughout America. Its professionals understood how much more convenient--and profitable--one annual campaign for overseas needs would be. Its leaders, in october 1938, actually proposed to the two major partners "a new type of combined drive," the "new" United Jewish Appeal for Refugee and overseas Needs, and a $\$ 20,000,000$ campaign for 1939 with prearranged formulas for allocations. 16

The plan included CJFWF representation on an allocation committee to distribute the anticipated surplus part of the funds raised, if the minimal commitments to the Joint Distribution Committee $(\$ 5,000,000)$, United Palestine Appeal $(\$ 2,500,000)$ and $\operatorname{NCCR}(\$ 2,000,000)$ were met, and a stipulation that the 1939 agreement, in order to eliminate allocation struggles across the land, cover all 225 CJFWF community campaigns in the united states. In the words of the CJFWF president, "this request was based on the desire to avoid friction arising from competition for funds in welfare fund cities; fundamentally, it was based on the belief that a fair agreement would produce maximum giving." Concomitantly, throughout 1939 and 1940, CJFWF would sponsor regional seminars for community leaders on how to develop community harmony and, 
"without sacrificing individual points-of-view," maintain
combined fundraising. 17

The combined UJA did meet with considerable economic success, although failing to reach the $\$ 20,000,000$ goal (about $\$ 16,250,000$ was raised in the 1939 campaign). Indeed, the UJA was considered so successful that it was renewed again for 1940, although not without months of delicate negotiations and a change in the allocations. 18

The negotiations between the JDC, UPA, and NCCR, together with the CJFWF representatives, were tense and heated. The UPA and JDC forced the NCCR to accept a maximum of $\$ 2,500,000$, and thus solved the simplest controversy. But the JDC stood pat on its conditions for uniting: a 75-25 split in its favor, after the NCCR allocation; permission to solicit "earmarked" donations (i.e. a gift designated to a specific European community); and a determined opposition to JNF "small coin" collections remaining outside the UPA alocations. Claiming its own needs exceeded $\$ 20,000,000$ (more than was raised in 1939 altogether), the JDC refused, for several months, any compromise, even though the UPA continually pointed out that this would make its share less in 1940 than in 1939. Proposals and counter-proposals flowed during November, December, and January, with UPA-JDC negotiating committees meeting nearly every week, for four to five hours at a time, at CJFWF and UJA headquarters in New York. The JDC stalling took its effect on the UPA, and although the "guaranteed sum" for the united 1940 campaign was up $\$ 750,000$ $(\$ 10,250,000$ from $\$ 9,500,000)$, only the UPA allocation remained the same $(\$ 2,500,000) .19$

During November of 1939 the CJFWF urged the UJA to expand in 1940 and include the organization for Rehabilitation Training, HIAS, and the Jewish Telegraphic Agency. Sidney Hollander (1881-1972), president of the CJFWF, argued, together with Jacob Landau (1892-1952) of the JTA for example, that the UJA enjoyed a fundraising monopoly in hundreds of American communities, and the demands of the "Big Three" strangled agencies with modest financial requirements. ORT, for its part, threatened to launch its own Greater New York drive for vocational training of refugees, but the UJA of Greater New York promised ORT \$130,000 from its campaign in exchange for a promise not to initiate an independent campaign. 20

The $\$ 23,000,000$ (this was the "minimum expectation") goal of the 1940 UJA campaign, announced on 1 February by co-chairmen 
Jonah B. Wise and Abba Hillel Silver, guaranteed $\$ 10,250,000$ to the JDC $(\$ 5,250,000)$, UPA $(\$ 2,500,000)$ and National Refugee Service $(\$ 2,500,000--$ formerly the NCCR $)$, and again set up an allocation comittee to divide the excess. This change--which promised to the agency aiding German Jewish refugees in America the same sum as the zionists were to receive--soon proved abhorrent to the zionists. But this campaign too enjoyed great success, with about $\$ 14,250,000$ raised in 3,371 communities. ${ }^{21}$

The bottom line was that despite its limitations, the "new" UJA of 1939 and 1940 raised considerably more than separate fundraising had ever secured (a total of $\$ 30,500,000$ ). Nevertheless, dissatisfaction continued throughout 1939 and 1940--despite public claims of "cordial relations and generous cooperation"-as each of the constituent organizations demanded a greater distribution of income. On 26 December 1940, despite vigorous efforts by the CJFWF to maintain the appeal, Hollander, silver, and wise reluctantly announced that because of failure to agree on the proportion of funds for the National Refugee Service, all three major agencies of the UJA would have independent fundraising campaigns in 1941.22

The public statements as to why the negotiations broke down all agreed on the cause. According to a JDC source, for example, "an apparent bitter struggle unfolded for funds," and the "major difference of opinion arose with respect to the amounts deemed requisite for the activities of the National Refugee service." This was indeed the crux of the matter; for the zionists felt that they not only deserved more than the 23 percent allocation they received in 1939 and 1940 , but that it was outrageous for the NRS to receive an equal allocation (actually, a slightly larger one). ${ }^{23}$

The zionists claimed that the "trickle" of refugees that came to America and were aided by the NRS could never be compared, either in numbers or in need, to the thousands who fled to palestine. For the NRS to then demand of the UJA--and the demand met with JDC support on retaining the 1940 proportions for the 1941 campaign--a $\$ 4,250,000$ allocation in 1941 campaign discussions, was too much for the zionists. The UPA announced that the "UJA represented a surrender of Jewish nationalism to assimilation," and therefore the UPA refused to continue its participation in the United Jewish Appeal. 24

One day after the announcement of the end of the UJA, the UPA announced a $\$ 12,000,0001941$ goal (compared to the less than 
$\$ 3,000,000$ it received from the UJA in 1940), and, despite intensive last-minute efforts by the CJFWF to prevent one, launched an independent campaign. Henry Montor, the UPA's executive director, claimed a few months later that at that very moment the UPA had "covered the entire country with campaign men of experience and competence."

Five weeks later the NRS launched its own $\$ 4,340,000$ campaign and the JDC an $\$ 11,250,0001941$ campaign (compared to the $\$ 6,050,000$ the Joint received in 1940). For the CJFWF, these last two announcements were most unwelcome news. The annual CJFWF General Assembly was meeting in Atlanta from 31 January-3 February 1941, and the independent campaigns presented the CJFWF with an apparent end to harmonious and equitable allocation procedures. 25

Fortunately, however, the CJFWF had already responded to the impending breakdown of discussions in the fall of 1940 by organizing regional conferences on "budgeting of local funds for overseas agencies," and by the end of its meeting the general assembly recommended that a "national advisory budget service for overseas agencies"--consisting of CJFWF representatives--be established to formulate advisory recommendations to local federations on the allocation quotas for the UPA, JDC, and NRS. In this way, the CJFWF hoped, the JDC, UPA, and NRS, when appealing to local communities for support, would be informed of a predetermined allocation percentage for each organization. 26

The Reconstructionist, in a series of editorials, bitterly attacked this CJFWF plan. It argued that local discussion, even controversy, over priorities and allocations was the heart of "communal democracy," and "predigested facts" usurped this democratic process. The American. Jewish Congress' organ, Congress Bulletin, joined in condemning the CJFWF plan, arguing that the national advisory budget service would be stacked with JDC-NRS supporters (i.e., non-zionists) "bound by solidarity of class interest and a bond of understanding," and was tantamount to a "declaration of war against the zionist movement." 27

The zionists themselves, to no one's surprise, agreed with these opinions. Lipsky noted how the desire to support generously the NRS--and with it Jewish refugees to America--was an attempt to "control" the zionist movement. The NRS supporters, on the other hand, countered by demonstrating repeatediy that not only was every cent of their 1939 and 1940 allocation spent, but the funds allotted were not even 
sufficient to provide the emigrant refugees to America with the proper support. 28

Concomitant with public discussion about how to respond to the anticipatd independent campaigns, the CJFWF leadership worked privately to rally the UJA partners back into an alliance. And these efforts, so vital for maximum fundraising, proved successful. In mid-February the JDC announced it was willing to reopen negotiations with the UPA, and would accept what amounted to binding arbitration on the NRS allocation by a neutral group. The UPA agreed to discussions, and on 5 March the JDC, UPA, and NRS were ready to announce that "in response to the overwhelming desire of American Jewry" a United Jewish Appeal had been "reconstituted" for 1941.29

A $\$ 25,000,000$ goal for 1941 was announced on 9 March, with the JDC guaranteed $\$ 4,275,000$, the UPA $\$ 2,525,000$, and the NRS $\$ 2,000,000$ (of the first $\$ 8,800,000$ ), and an allocation committee was also again established to divide the surplus-according to a prearranged quota. "The emergency position of millions of Jews," the UJA co-chairman noted, "requires cooperative action among Jewish leaders in America." 30

The 1941 "reconstituted" UJA was a triumph for the zionists. The 1940 UJA funds had been allocated, in percentages, as follows: JDC $(48.6$ percent), NRS (28.1 percent), UPA (23.3 percent), and the UPA had refused the demand of the JDC to continue this division for another year. The 1941 drive would divide the first $\$ 8.8$ million as follows: JDC (48.5 percent), UPA ( 28.6 percent), NRS $(22.9$ percent), and would divide the surplus 63-37 between the UJA's two "full" partners, the JDC and UPA. Thus the UPA would receive 28.6 percent against both the JDC and NRS, and 37 percent against the JDC alone; its 1941. "guarantee" would exceed that of 1940; and the guarantees of the JDC and NRS were down almost $\$ 1,000,000$ and $\$ 1,500,000$, respectively. ${ }^{31}$ By the time the 1941 UJA campaign had ended, and the almost $\$ 3,000,000$ excess had been divided, the UPA had received $\$ 3,325,000$. This was $\$ 400,000$ more than in 1940 , although the campaign itself yielded $\$ 2,600,000$ less than in 1940, and the gains for the UPA, of course, came at the expense of the JDC and NRS. 32

It was the CJFWF which realized that maximum fundraising among American Jewry needed a Palestine component and that harmonious allocating needed a UJA. This made the "reconstituted"--and permanent ever since-UJA posible. Upon 
this all three constituents of the UJA agreed. In addition, as we have seen, the needs of world Jewry proved to be a major factor in the creation of the UJA, for the events of the $1930 \mathrm{~s}$ were the watershed that led to demands for joint fundraising in American Jewish life. The merger of the JDC, UPA, and NCCR into the UJA not only quickly reorganized national Jewish philanthropy, but virtually every local Jewish federation as well. 

On 31 December 1945 the United Jewish Appeal completed seven years of activity as the largest Jewish fundraising body in the United States. During the period from 1939 to 1945 , American Jews contributed more than $\$ 124,000,000$ to the United Jewish Appeal's combined campaigns for the Joint Distribution Committee, the United Palestine Appeal, and the National Refugee service. These funds rescued 162,000 Jews from the Nazi death machine and helped to stem the tide of suffering and homelessness for Jews in many parts of the world through a three-fold rescue and reconstruction program, including war relief and rehabilitation in overseas lands, the upbuilding and defense of the Jewish homeland in Palestine, and assistance and adjustment aid for refugees in the United states. The United Jewish Appeal provided this aid in a critical period of Jewish history--a period which brought the gravest challenge to the existence and survival of the Jewish people. 1

For its far-flung program in many lands, the JDC received $\$ 64,376,000$; for the upbuilding, defense, and war mobilization of the Jewish National Home in Palestine, the UPA received $\$ 42,058,000 ;$ and for integrating newcomers in the United states and preparing them for citizenship, the NRS received $\$ 13,455,000$.

organized in the same calendar year as the outbreak of World War II, the UJA found itself confronted with greatly increased--even unprecedented--responsibilities as a result of the Nazi invasion of Poland in september 1939, and the wholesale extermination of European Jewry which followed. As the Nazis drove added numbers from their homes, the ranks of the refugees swelled and larger programs of aid had to be instituted. When some roads of escape were barred by the spread of war, other avenues of emigration had to be established to snatch the victims from the fires of destruction. UJA efforts saved large numbers from annihilation and provided many thousands of others with the opportunity to rebuild their lives in new homes in Palestine, the United States, and other lands. 2

The JDC continuously enlarged its program of assistance in both Allied and neutral countries, as its allocations from the UJA increased each year during the war from $\$ 5,600,000$ and $\$ 5,800,000$ in 1939 and 1940 , respectively, to $\$ 16,800,000$ in 
1945. Although cut off from direct aid by the barriers of war, Jews in Nazi-occupied lands continued to receive a measure of emergency relief through a plan evolved by the JDC prior to the disruption of normal communications whereby responsible leaders of welfare agencies borrowed money and commodities from local sources for repayment after the war. Through this arrangement the JDC provided help for Jews in Poland, Romania, France, Hungary, and even Shanghai.

UJA funds were also used by the JDC to aid an average of nearly a million persons annually; to enable more than 100,000 refugees to escape to the Western Hemisphere and Palestine; to aid more than 50,000 refugees in spain, Sweden, Switzerland, and Portugal; to organize special relief and rehabilitation programs for Jews in liberated areas of North Africa; to promote the integration of more than 130,000 immigrants in Latin American lands; and to send food packages and medical assistance to Jewish refugees in Asiatic Russia. 3

With the coming of war the Jewish community in Palestine faced new problems which required added support from the UPA. The Jewish homeland's economy had to be placed on a total war footing, more than 50,000 of its able-bodied young men and women had to be mobilized for the British Army, and its agricultural and industrial facilities--including 400 new industries and forty-one new agricultural settlements established during these years--had to be geared to maximum production to aid the Allies in the strategic Middle Eastern theatre of war. At the same time, the program of development and upbuilding (housing, security, relief, education, and the like) had to be advanced to make possible the continued immigration and settlement of nearly 70,000 homeless Jews from war-ravaged Europe who obtained the precious certificates issued by the British through the Jewish Agency. 4

The small and poor Palestine Jewish community itself annually contributed generously to the UPA. The Jewish National Fund, for example, pledged to raise L250,000 in 1943, and the entire country successfully completed a $\$ 1,000,000$ war Needs Fund drive. This was even more remarkable considering that one-third of Palestine Jewry was under the age of eighteen.

The National Refugee service served as liaison on refugee matters between washington and communities from coast to coast, carried on its relief, employment, resettlement, vocational retraining, and other traditional services--including more than 
19,950 (through 1942) job placements and 5,000 (through '42) professional placements--and actively facilitated naturalization and the removal of obstacles in the way of hiring refugees for war production. 5

The "reconstitution" of the UJA in 1941, and its large-scale, unified campaigns of the war years, should not suggest that the road to campaign allocation agreements between the three major constituent organizations was a smooth one. It was not, and this was true year after year. But when the discussions betwen JDC and UPA representatives about the 1944 UJA began, a new factor emerged as a serious obstacle. ${ }^{6}$

Actually, the complaints about the Jewish National Fund for palestine were not new, only their stridency. For several years, the JDC had complained to the UPA about what it considered an unfair arrangement benefitting the UPA and hence Palestine. When the UPA proposed that the 1942 UJA ratio (41.54 percent for the UPA and 58.46 percent to the JDC) be retained in 1944 , Isaac Levy of the JDC asked for the floor and read a prepared statement on the activities of the JNF. Essentially, the JDC pointed to "traditional" collections of the JNF, beyond the framework of the UJA, which for many years had "raised funds for one partner exclusively, outside the contractual agreement."

These collections included, in 1943 alone, $\$ 150,000$ from "pushkes" or boxes, $\$ 300,000$ in Hadassah "small coin" collections, $\$ 163,000$ in "Trees for Palestine" sales, and $\$ 138,000$ in "Golden Book" inscriptions--a total of more than $\$ 750,000$. The JDC representatives demanded that the 1944 JNF totals be deducted from the UPA allotment in the 1944 campaign and added to the JDC totals, for "people who might be brought into the work of the UJA were devoting their energies instead to the JNF." The UPA responded that these traditional collections were always outside the agreement and must remain so (actually, half of the JNF proceeds were turned over to the UPA), but agreed to allocate to the JDC an amount equal to any dollars over $\$ 750,000$ achieved by the JNF. 7

Following several weeks of tough and often fierce bargaining, the UPA agreed to a $60-40$ split of the first $\$ 14,000,000$ from the 1944 campaign in return for the first $\$ 600,000$ over $\$ 10,000,000$ as compensation to the JDC for JNF collections and a $\$ 1,100,000$ ceiling on JNF collections in 1944. Another week was needed for agreement on what to do with 
any JNF excess over $\$ 1,100,000$ and how to count JNF "pledges" of which only a part was paid in 1944. After five weeks of more than twenty UPA, JDC, and JNF executive, board, committee, and sub-committee meetings, a compromise was reached and an agreement signed. Not everyone, however, was pleased. Later that year the head of a local campaign, st. Paul's United Jewish Fund and Council president, H.K. Wolkoff, attached a note to his community's check $(\$ 110,000)$ to the UJA. He stated that

this 1944 allocation to the UJA is made with the expectation that both the UJA and the JNF will prevent the conduct of another drive for JNF such as that of 1944 . . . There is an implied note of threat in this missive. 8

The UJA sought, throughout these years, to express its goals and objectives whenever possible in non-sectariain language, and to win the enthusiastic support of non-Jewish Americans. Abba Hillel Silver, addressing the UPA national conference early in 1942, assured his audience that "every dollar given to palestine is a defense bond for democracy"; Nathan straus, Administrator of the U.S. Housing Authority, noted that "Palestine requires the widest assistance because its brave pioneers are fighting for the survival of democracy"; District Attorney Thomas E. Dewey stated that "in contributing to the UPA we express our faith in the democratic spirit" and that the "UPA is vital Americanism which exalts the human spirit and supports the democratic way of life"; Professor Joseph Chamberlain of Columbia Law School, opening the UJA Long Island division 1941 drive, said that "the UJA preserves the democratic way of life expounded by Abraham Lincoln"; Governor Lehman of New York told the UJA women's division that "the UJA upholds a great American tradition-fellowship and brotherhood," and in a speech at the 8 th Annual "Night of stars" benefit show, he hailed the "UJA defenders of democracy" who "sanctify human values, the cornerstone of enlightened civilization." 9

It comes then as no surprise to find President and Mrs. Roosevelt enthusiastically embracing the UJA as a supportive, not competing, relief agency. In 1941 FDR noted that "the arms of Judea and America are interlocked to bring common victory to the ideals of the ancient prophets which have been enshrined in 
the Anerican way of life." In 1942 he spoke of the UJA as a "humanitarian front"; in 1943 he noted that the UJA "sustains the spirit of freedom and democracy"; and in 1944 he stressed that the UJA "guards the rampart of Jewish preservation, indeed of world civilization's preservation." Eleanor Roosevelt was equally enthusiastic, and often served as the keynote speaker at UJA women's division campaign "kick-offs." I0

on only one occasion during the war years did the "reconstituted" UJA almost collapse. As in 1941, the UPA and JDC, on the eve of the 1945 campaign, could not agree on the allocation percentages, as the UPA submitted a voluminous budget which detailed extraordinary needs and requested an amount greater than the entire 1944 UJA goal. In withdrawing, late in February, the UPA delicately stated that it did so to "be in a position to bring to the fullest attention of the Jews of America the opportunities offered by a contribution to Palestine Jewry." When Council of Jewish Federations and Welfare Funds arbitration efforts failed, the UPA language became more bitter and defensive, and the organization appeared to toughen its insistence that it not "remain in a subordinate position." 11

The second "reconstitution" of the UJA came only several months later, after both the UPA proposed, and the JDC agreed, to binding arbitration by the United states War Relief Board. In return for a better split (57-43 rather than 60-40), the UPA yielded to the JDC on the issue of "earmarking" gifts, allowing landsmanschaftenn to earmark their UJA donations for a special hometown project and permitting the JDC to designate 57 percent of the gift for this specific project. Strong UPA opposition to earmarking was mitigated, to some extent, by the UPA's awareness that 43 rather than 40 percent meant an extra million or even more dollars in its allocation. ${ }^{12}$

The man who led the UPA forces, informally, during these years was the former executive airector of the United Palestine Appeal (1930-1939) and the head of the UJA for its first twelve years of existence. Henry Montor (1905-1982) was born and raised in Montreal, and after deciding to leave the Hebrew Union College, where he was preparing for the rabbinate, he completed his B.A. at the University of Cincinnati. He wrote for and edited, The New Palestine, an American Zionist publication, for a few years, and served briefly as the publicity director of the UPA before becoming its executive 
director and, eventually, the executive vice-chairman of the United Jewish Appeal (1939).

Montor introduced the concept of large scale advertising in the general press, the abundant use of radio, unprecedented campaign goals, and numerous other UJA campaign solicitation tools which over the years became the accepted techniques in Jewish fundraising and which will be delineated in this and three subsequent chapters. No one, in the words of an admirer of his, "ever matched him in the art of fundraising." 13

During the war years the two most significant internal developments for the future of the UJA were the creation, by Henry Montor, of a coordinated system of field representatives and a new ideological approach to the annual campaigns. Both of these accomplishments went virtually unnoticed at the time, but by the 1950s UJA leaders and others fully understood their value.

The field representatives were not merely to visit communities and report to the UJA, but to see that communities were properly organized for maximum campaigning and to remain involved with a community's campaign organization until all its funds had been sent to headquarters. This network of representatives was so tightly organized that the UJA in New York knew the proposed weekly itinerary of every representative--including where he could be reached by phone during each morning and afternoon--on the Friday of the preceding week.

Each representative was required to submit a detailed, typewritten report on every community contact within two days of the visit. These reports reveal the representatives to have worked with community leaders to set-up campaigns: especially to show them how to compile solicitation lists; organize "big gift" functions and campaign solicitation teams; distribute pledge cards; and collect pledges from the current and earlier years. The careful building of campaign organizations throughout the war years would make possible the unprecendented campaign of 1946.14

By the eve of the 1941 campaign, Henry Montor had sufficiently analyzed the 1939 and 1940 campaigns to realize, quite accurately, that the curve of popular response had not followed the graph of critical developments in Jewish life. The outbreak of war failed to arouse American Jewry, and the saturation level of pictures of horror and tragedy and 
suffering had not brought a commensurate positive response. Montor concluded that the vastness of tragic events had overwhelmed the community, appeals to the emotions had been worn thin, and no matter how desperate the situation of European Jewry in 1940 , it had produced not increased sympathy or concern but, on the contrary, a negative reaction. Why, he asked? Because the feeling emerged that the situation was hopeless, too vast for any individual or even group to cope with.

Montor proposed to the handful of laymen who composed the largely ceremonial executive comnittee that the UJA subordinate the "despair and tragedy" approach (war's devastation, starvation, Nazi persecution) of late 1939 and 1940, and continue to reject the domestic issues (refugees, defense of rights, civic defense, exposing subversions) as fundraising motivators. He urged, rather, that the UJA campaign stress Jewish courage and independence in palestine, not hopeless misery but inspiring heroism, not doom but survival, not wandering but resettlement in palestine.

Thus Montor urged not merely an emphasis on Palestine, but the positive industrial and agricultural growth and development therein. He argued repeatedly, and the wartime UJA appeals occasionally echoed his arguments, that rather than portray Palestine's plight in the direst of terms with ads suggesting Palestine Jewry stood on the brink of economic collapse, UJA ads ought to portray the positive developments and growth of Palestine. While this was to change radically in the campaigns of 1947 and 1948 (see chapter four), during the war years Montor had to subordinate his efforts to present a positive portrayal of Palestine to the vastness of the European tragedy. 15 

CHAPTER 3

THE FIRST $\$ 100,000,000$ CAMPAIGN: 1946

More than 1,500 American Jewish philanthropic leaders gathered in Atlantic City in December 1945,1 and adopted the unprecedented goal of $\$ 100,000,000$ for the 1946 United Jewish Appeal for Refugees, Overseas Needs, and Palestine. One eye-witness recalled:

The conference of 1945 was an historic meeting because it changed the quantum. There was a terrible two or three day fight, in which everyone said it's ridiculous to make a goal of one hundred million dollars--it cannot be reached--we will look foolish, silly--why should we do it? I pushed and fought. I fought against all the delegates from all the communities, and the conference passed a goal of $\$ 100,000,000.2$

The delegates agreed to distribute the funds among the Joint Distribution Committee (57 percent), the United Palestine Appeal ( 41 percent), the National Refugee Service (1 percent), and the Jewish Welfare Board ( 1 percent). This incredible goal exceeded the total UJA revenues during all of the first six years of its existence (1939-1944), ${ }^{3}$ more than tripled the 1945 campaign goal of $\$ 32,000,000$, demanded of New York City alone an amount $(\$ 35,000,000)$ greater than the entire American Jewish community raised in 1945, and was widely believed, even by the executive committee, to be a "wild dream." And yet, the campaign enjoyed such success that even before launching the fall campaigns in those cities which had delayed their fundraising, leaders of these communites began to describe their once "impossible" quotas as "minimum requirements," and UJA leaders could even begin to send forth trial balloons which proposed a $\$ 200,000,000$ campaign for 1947! This chapter will attempt to demonstrate how the UJA achieved what many thought impossible. 4

The UJA officially "kicked-off" the 1946 campaign with the first national "big gifts" meeting ever held. Since its inception in 1939, the UJA had assembled potential and actual large givers in their own communities, and solicited them as a group at a meeting, dinner, or other special occasion. Now, several hundred men and a few women as well gathered in washington, D.C., on 24 February 1946. The UJA informed them in advance that no gift under $\$ 10,000$ would be acceptable, and the strategy worked. 
Bernard Baruch delivered a rousing address, and Edmund $I$. Kaufmann (1886-1950), national chairman for initial gifts and president of kay stores, after himself pledging a quarter-million dollars, then called each of the names aloud, and waited until the individual announced his or her pledge. The family of the late Julius Rosenwald (1862-1932) pledged $\$ 1,000,000$, the relatives of the late Felix $M$. Warburg $\$ 500,000$, and so on until all 350 persons present had announced their gifts. Henry Montor, the executive vice-chairman of the UJA and the man who conceived the idea of the gathering, called it "the greatest outpouring of generosity ever witnessed in the history of American Jewry, perhaps of America." The momentum of the evening was not permitted to slow down one bit; the following day twenty of the national leaders met with president Truman and heard him publicly announce: "I will endorse the campaign wholeheartedly." Montor, whose vision and chutzpah were behind the unprecedented goal, was already confident of attaining it: ${ }^{5}$

The national big gift success carried over to the big gift affairs of the local campaigns. Philadelphia, whose $\$ 6,000,000$ goal made it, next to New York, the largest spring campaign, eliminated the private, individual solicitation pattern of previous years and used a dinner, patterned after the national event, to launch its campaign. Names were called aloud, gifts announced, and by the time only one-third of the persons present had announced their pledges, 50 percent of the community's goal had been achieved. The "special gifts" affair in the nation's Capitol saw 625 persons give $\$ 600,000$ of the nearly $\$ 1,000,000$ communal goal; in Boston, the 400 present at the big gift dinner pledged more than $\$ 2,100,000$ (vs. $\$ 806,000$ in 1945) with thirty-four gifts (vs. two in 1945) over $\$ 25,000$; in South Bend, the big gift luncheon raised 130 percent more than the entire 1945 capaign; the same eighty men at the st. Paul special gifts dinner who had given $\$ 99,000$ the year before now gave $\$ 267,000$; the same fourteen men in tiny Danville, Virginia who gave $\$ 3,730$ in 1945 pledged $\$ 15,210$ in 1946 ; while in Rochester, the same forty big gift donors who gave $\$ 120,000$ in 1945 pledged $\$ 302,000$ in 1946. Montor's insistence that "only good organization and follow-up can produce maximum attendance at a big gift meeting" was adhered to in community after community. ${ }^{6}$ 
For Montor, "good organization" meant primarily three things: getting the biggest givers to big gift meetings; private solicitation before the meeting; and "card-calling" at the meeting itself. Montor knew that if a man came to the meeting, he would give more. He never knew how much more, but a few thousand dollars multiplied by the men in the room could be sizeable. So he urged, in his memoranda to communal executives, that pressure be placed on men to come to a big gift meeting.

Further, Montor urged these same leaders to see each invitee privately, "face-to-face," before the meeting, in order to explain the campaign's critical needs, suggest a higher level of giving, and, if possible, commit the man to his new rating before leaving.

Finally, at the meeting itself, "good organization" meant card-calling. Following a brief but inspirational speech by someone with the latest report from Europe or palestine, the host called each man's name (from a carefully preparea card with both his previous pledge and the hoped for current pledge listed) and--Montor repeatedly urged--the amount he gave the previous year. Then encourage, Montor directed the solicitors, the man to "stand and publicly pledge" before "friends and neighbors." Never, he told leaders, only call names and ask "How much will you give this year?" but let every man in the room know every other man's level of giving the previous year. This will prove "most effective in increasing a man's gift," Montor concluded, and his basic program for big gift fundraising has not been seriously altered in three subsequent decades. 7

At the same time as the UJA helped communities organize innovative kick-offs, it spurred an effort to establish non-sectarian and/or Christian committees to independently support the UJA. In New York, Montor and other national and local leaders appealed to the Rockefeller family; John D. Rockefeller donated $\$ 100,000$ in securities, while Nelson organized and chaired a community comittee of New York [Christians]. At the Committee's initial dinner at the Waldorf-Astoria hotel, broadcast by cBs radio, 8 Henry Luce donated $\$ 20,000$, Marshall Field pledged $\$ 25,000$, John Hay Whitney $\$ 20,000$, while Loew's $(\$ 50,000)$, stanatard oil of New Jersey $(\$ 25,000)$, and United Rayon $(\$ 25,000)$ later made corporate pledges. The Pensacola Citizens Committee, ${ }^{9}$ which 
devoted all Catholic and Protestant church services one sunday to the UJA; the Non-Sectarian Community Committee of Greater Kansas City, where 125 civic leaders inaugurated a community UJA week; Worcester, whose "Concerned Christians" pledged to raise $\$ 100,000$ for the UJA; and Kinston, North Carolina, where a group of Christian leaders pledged to match the Jews dollar for dollar during their simultaneous ten-day campaigns, were but four of the many different ways the non-Jewish community expressed its support. Many of these non-sectarian and Christian campaigns were aided by the UJA strategy of placing, for the first time, full page ads in the local daily press. 10 The primary goal, of course, was to reach Jews, especially those who did not read the Anglo-Jewish press, but such ads obviously heightened awareness of the UJA campaign among non-Jews too. 11

The first week in May alone saw the launching of more than 200 UJA spring campaigns, highlighted by the New York $(\$ 35,000,000)$, Philadelphia $(\$ 6,000,000)$, Detroit $(\$ 3,560,000)$, and Cleveland $(\$ 2,677,000)$ campaigns. Only one community, according to UJA archives, balked at its quota: the national "quota committee" had assigned York, Pennsylvania a $\$ 70,000$ quota; the York Jewish Federation rejected this amount and announced a figure more than 50 percent larger: These campaigns, and those still to begin in the fall, were greatly aided by the introduction of UJA regional conferences arranged throughout the year. There, leaders from several communities provided each other mutual support in undertaking what seemed to be extraordinary goals, shared information and strategies in workshops and seminars, and heard rousing campaign oratory. At least twenty-three regional conferences took place in the spring of 1946 alone, and Montor acknowledged that these were "essential keys to the campaign." 12

The results of the spring campaigns exceeded everyone's expectations. Miami, which gave the UJA $\$ 170,000$ in 1945 , surpassed its $\$ 500,000$ UJA quota easily; Indianapolis' campaign unfolded so successfully that it voluntarily raised the $\$ 400,000$ quota it accepted in January to $\$ 500,000$ in April; Dallas, assigned a $\$ 400,000$ quota, announced at least $\$ 750,000$ for the UJA; Buffalo surpassed its half-million dollar quota in ten days, adopted and surpassed both its new $\$ 650,000$ quota and then its subsequent $\$ 750,000$ quota and by late May approached the $\$ 900,000$ mark. Similar reports flowed into UJA national 
headquarters in New York from st. Louis, Cleveland, Woonsocket, Memphis, Dayton, Duluth, and even Crawfordsville, Indiana where all eighteen Jewish residents contributed and surpassed their $\$ 8,500$ quota. 13

The "divisions," organized for the first time on the national level, played an important role in these spring campaign successes. previously, for example, a local hotel division solicited Jewish hotel owners in Atlantic City or Las Vegas; now a national hotel division enabled the UJA to sweep local hotel owners into the national orbit and as a result--expand their contacts and contributions. Thus the Miami hotel division, which raised $\$ 20,000$ in 1945 , broke the $\$ 200,000$ barrier in 1946. Other national divisions had significant impact upon their parallel local division-especially the enormously important trade and industry division--where Harold J. Goldenberg (1908-1977) took a leave of absence from his own Minneapolis business to head this division's campaign--as well as the publishers and newsdealers, shoe, jewelry, ladies underwear, and poultry division. ${ }^{14}$

side by side with this reorganization was the emergence of a national women's division which functioned as more than an appendage to the "men's" campaign. Mrs. David (Adele) Levy (1892-1960), the daughter of the late Julius Rosenwald and the first national chairperson of the women's division, launched its campaign in $\mathrm{st}$. Louis on 4 March before 300 "leading" women, and made a whirlwind coast-to-coast tour during March to kick-off women's division campaigns. The UJA, recognizing that "women now give gifts that compare favorably with men," was rewarded by its attention to women contributors; in New York City, for example, the women's division hit the $\$ 3,000,000$ mark by June, while by the end of september 195 women's divisions had completed spring campaigns and transferred nearly $\$ 9,000,000$ to the UJA headquarters. ${ }^{15}$

By the time the UJA launched 1,500 fall campaigns in September-headed by Chicago $(\$ 9,000,000)$ and Boston $(\$ 5,400,000)--$ Montor had assured the national campaign council that the $\$ 100,000,000$ goal would not only be met but that there would be a clear excess. He noted, correctly, that the campaign success was the result of, in part, a "supercolossal year for retailers," but, primarily, not viewing "old methods of fundraising, outworn slogans, and established 
procedures. . as sacrosanct merely because they were part of the past." He praised, as well, the use of "imagination of the highest order." Local federations and welfare funds, through which the UJA conducted its campaigns, were instructed to speak of their fall quotas not just as goals but as "minimum" goals. Montor told the campaign council in July that there now existed widespread understanding that the $\$ 100,000,000$ goal represented the barest minimum requirement, and the Chicago and Boston campaign literature echoed this. Chicago, in fact, was so optimistic that its leaders attempted to raise at least $\$ 1,000,000$ at every single major trade or division gathering. The first three events, at least, succeeded. Chicago, and other cities, were helped by the fact that since every dollar which was transferred from a local campaign to the national UJA was immediately dispersed to, and spent by, one of the constituent agencies, the fall campaign slogan of "Additional Dollars for the Saving of Additional Lives" was accurate. ${ }^{16}$ There seemed to be, indeed, no limits to the UJA's needs, and the same techniques which worked so well in the spring also brought unprecedented totals in the fall. Boston, for example, nearly reached $\$ 7,000,000$, and before many of the fall campaigns came to a close the UJA announced that more than $\$ 102,000,000$ had been raised. ${ }^{17}$

In addition to the techniques of organization and solicitation by the UJA to achieve its unprecedented 1946 totals, two additional Eactors ought to be noted--one external and the other internal. First, the 1946 campaign represented the first full post-war effort at Jewish fundraising. Although the Holocuast, per se, was not utilized at all by the UJA--probably because it was yet far too early to absorb its impact--the refugees' plight was prominently displayed. Few could resist the appeal to provide relief, rehabilitation, and reconstruction to the hundreds of thousands of helpless and despairing men, women, and children roaming Europe or searching for a new home elsewhere. What the Saturday Evening post of 5 october 1946 called "The second Exodus of the Jews" received extensive publicity in the mass media, and the struggle for survival of the remnant of European Jewry was widely understood.

secondly, the UJA launched the 1946 campaign with a most unusual and controversial solicitation procedure, the single most crucial internal factor in the campaign. One of the 
resolutions adopted at Atlantic City in December 1945 said in part:

To assure the unprecedented generosity which alone will make possible the attainment of a goal of $\$ 100,000,000$, we urge that every contributor be informed that his gift in 1946 will not be used as a basis for comparison in any succeeding year.

This meant, in practice, that the UJA campaign of 1946 solicited a "one-time gift" with the hope that "the factors making for misery and homelessness would be eased or entirely overcome." Subsequent campaigns would, Montor stated explicit$1 y$ to the national campaign council, revert to 1945 levels of giving in determining how much to solicit. And, he went on, this "was not mere campaign strategy;" it was felt that "the evils of the Nazi era would be abated during 1946."18

At the UJA executive committee meeting of 12-13 October 1946 the top philanthropic leaders from all over the country made it clear to each other that the 1946 campaign succeeded precisely because of this premise. According to Leon $C$. Sunstein (1885-1958) of Philadelphia, "1946 was the crucial year and the basis of achieving the goal was as a 'one-time' gift." Frank Garson (1886-1955) of Atlanta echoed sunstein's words, and opened the lengthy debate which was to lead, finally, to the adoption of a $\$ 170,000,000$ campaign goal for 1947, i.e. the decision to respond to unanticipated crises in Europe by asking American Jews to give more in 1947 than in 1946. Mrs. David Levy, as others, acknowledged that some American Jews will expect us "to keep the pledge that we made to them," but most will understand that we now "face factors which not even the most pessimistic of outstanding governmental authorities had foreseen." "For," she noted with cogency, "does any one of [you] feel any poorer because of his gift to the UJA this year?" There was no reply. 19 



\section{CHAPTER 4 \\ AMERICAN JEWRY'S CAMPAIGN OF SACRIFICE: 1947 AND CAMPAIGN OF DESTINY: 1948}

On sunday afternoon 1 December 1946 in Atlantic City, 1,700 representatives of American Jewish communities endorsed a $\$ 170,000,000$ United Jewish Appeal campaign for 1947. The "one-time" giving of 1946 slipped into the background as the JDC, UPA, and United Service for New Americans (formerly NRS) faced "unexpected" and "unprecedented" needs, and submitted budget requests totaling $\$ 215,000,000$ for 1947 . Their needs included the return of 175,000 destitute Jews from the soviet Union to poland and Romania, and the almost simultaneous flight of more than 100,000 Jews from Polish, Romanian, and Hungarian persecution and poverty; the concentration of nearly 250,000 Jewish DPs in Germany and Austria; the largest immigration to Palestine since 1937; and increased Jewish immigration to the United States. ${ }^{1}$

The enormous goal did not emerge easily. The 413 member resolutions committee engaged in eight hours of vigorous debate before deciding that even if $\$ 22,000,000$ became available as a result of the final Act of the paris Conference on Reparations, and other Jewish communities raised $\$ 23,000,000$, there remained $\$ 170,000,000$ which American Jewry must raise to provide the minimal needs for 1947. Despite the pleas of some committee members to remember the pledge made in 1946 that the 1946 campaign was, in large measure, a "one-time gift," the overwhleming majority agreed that "new conditions of crisis" made void that pledge. ${ }^{2}$

President Truman, General Eisenhower, and the UJA general chairman Henry Morgenthau, Jr., launched the 1947 campaign in Washington, D.C. on 22-23 February by announcing twenty gifts of more than $\$ 20,000$ each. Heading the nearly $\$ 3,000,000$ in advanced "big gifts" was the $\$ 1,000,000$ given by Julius Rosenwald, and the $\$ 500,000$ gift of Edmund I. Kaufmann (doubling his $1946 \mathrm{gift}$ ) on behalf of Kay Associated stores. ${ }^{3}$

The spring/summer campaigns of 1947 got off to a rousing start, led by New York City's attempt to achieve its goal of $\$ 65,000,000$ (vs. $\$ 35,000,000$ in 1946). A National Christian Committee of eighty prominent Americans, organized by Nelson $A$. Rockefeller and Eleanor Roosevelt, appointed Thomas J. Watson, 
president of IBM, as national chairman, and pledged not only large sums of money but also to work for the UJA in 225 cities and to organize citizen committees and church collections throughout the land. The synagogue council of America declared the first Friday and Saturday in May "UJA Sabbath" and urged all synagogues to offer special prayers for the campaign's success; governors of state after state declared a "UJA Week" or a "UJA Month"; the Saturday Evening Post, in an editorial on 19 April, urged all Americans to back the UJA; and Eddie Cantor, with frightening footage of DP camps and wandering refugees in the film's background, pleaded on the screen that "We Must Not Forget." 4

The most dramatic leadership in these initial campaigns of 1947 came from the UJA general chairman, Henry Morgenthau, Jr. (1891-1967), the former secretary of the Treasury (1934-1945) under Franklin D. Roosevelt. In early March, via special charter planes which flew while storms grounded commercial airlines, he visited seven cities in seven days and aroused tremendous excitement with his big gift keynote addresses. He pulled in $\$ 650,000$ (of a $\$ 1,000,000$ total goal) in one night in Dallas, moved Edgar stern of New orleans to double his announced gift to $\$ 250,000$, and in Richmond, Altanta, and Houston his charisma doubled the big gift totals of 1946. One month later, in the midst of sleet, snow, and heavy ice so severe his pilot lost his CAA license for one prohibited landing, Morgenthau visited five cities in three days and achieved big gifts totals far beyond 1946 record achievements. St. Louis gave $\$ 615,000$ (vs. $\$ 281,00$ in 1946), Omaha delivered $\$ 350,000$ (vs. $\$ 189,000)$, Wilkes-Barre raised $\$ 189,000$ (vs. $\$ 83,000)$, and Paterson, New Jersey reached $\$ 360,000$ compared to $\$ 194,000$ one year earlier. 5

Morgenthau not only brought a dynamic and moving message to these communities, but met with campaign leaders to emphasize the importance of utilizing the techniques the UJA felt were most successful. These included the open reading of pledge cards and the public announcement of the previous year's gift--"the single most helpful means of raising the largest sums of money"--and Morgenthau utilized these techniques everywhere he went with striking results. ${ }^{6}$

Despite Morgenthau's personal success, UJA campaign totals during the spring did not come close to the needs of the UJA's constitutent agencies. The most crucial problem was the 
elimination of UNRRA services and supplementary aid, as well as the U.S. Army DP feeding program on 30 June, and the failure of the successor agency, International Relief organization, to receive adequate financing. UNRRA, with a staff of 5,000 in Germany alone, was being replaced by an organization with 700 staff members to serve one million DPS.

But nearly as serious was the unprecedented borrowing of the JDC and UPA to meet even minimal needs. BY June, the JDC had borrowed $\$ 16,000,000$ from New York City banks $(\$ 8,000,000$ in long-term notes, $\$ 4,000,000$ in 60-day loans, $\$ 2,000,000$ al ready repaid, and $\$ 2,000,000$ due in two weeks), while the UPA had $\$ 20,000,000$ in loans and overdrafts at Palestine banks, and the USNA a loan for $\$ 1,000,000$. Obviously, the UJA needed cash immediately, and made every effort to convert spring campaign "pledges" into cash "donations." These efforts reached a peak during the "Ten Days of Remembrance," traditionally days of atonement and introspection, but proclaimed by Morgenthau as an opportunity for the "deep spiritual significance of the High Holydays to be a chance for stimulation of local solicitation. " 7

The fall UJA campaigns began immediately after the High Holydays, with new crises dominating the news. American correspondents reported 1,000 Jews each week fleeing renewed anti-semitism in the Balkans (mostly Romania), and placing extraordinary responsibilities on refugee organizations in Germany and Austria. JDC food shipments to Czechoslavakia and Poland in late 1947, as a result of UNRRA's exit, were double those of earlier in the year. And the 16,000 Jewish refugees in two British camps on Cyprus needed massive assistance. Like the spring campaigns, these too had a grand kick-off. ${ }^{8}$

Chaim Weizmann, the legendary zionist leader, arrived from Europe on the Queen Mary, and travelled to several cities to launch local campaigns, conveying the message that despite record pledges, the UJA was "as near the line of bankruptcy as [it] can be and still survive." And he was absolutely correct, for as of 5 september only $\$ 38,000,000$ in cash (vs. $\$ 42,000,000$ in 1946) had reached UJA headquarters in New York. Spring campaigns had to provide two-thirds of the annual goal for it to be reached; the 1947 spring cash totals comprised only 22.5 percent of the $\$ 170,000,000$ goal. In practical terms, this meant, for example, that the JDC had $\$ 141,000$ in the bank on 3 september and, despite hugh borrowing, had turned down more 
than $\$ 1,500,000$ in requests from its European agents in August alone. Simply stated, if more money had been available, more could have been done. ${ }^{9}$

But the most significant aspect of Weizmann's visit was not the extent to which he brought in cash, nor even the number of cities he spoke in, but the content of his message. He gave life to a crucial change in direction Henry Montor had been developing for several years. 10

Montor understood that the focus of the UJA campaigns throughout the war, and again in 1946--the European refugees and foreign relief-needed to be changed in 1947 and 1948 to the centrality of the palestine issue. The problem was that for years the UJA had harped in its campaigns on the theme of Jewish needs and anguish in Europe on the one hand, and "the ample resources in palestine to meet these needs." To mobilize funds for Palestine, "more realistic and clearcut concepts" must now be used, for the UJA had actually "rendered American Jews incapable of accepting palestine in its natural limited proportions."

With the fall campaigns of 1947, both UJA publicity and Weizmann began to depict Palestine as a "re-nascent country" rather than as merely a "refugee haven." Weizmann spoke repeatedly of the end of the refugee problem, and the new centrality of upbuilding palestine. This meant the need for massive, long-range, social, and economic planning and programs-only possible through foreign funds--and a strong distinction between the JDC, a foreign relief agency, and the UPA, decidedly not a relief agency. It was this distinction which Montor urged repeatedly in letters to Palestine, and which Weizmann articulated. This new emphasis, while not yielding unusual results in the fall of 1947, was central to the extraordinary campaign of 1948. For even before the fall campaign of 1947 finished, the UPA executive board called for a $\$ 250,000,000$ goal in 1948: (See Table 4:1)

The opening proposal for allocating the 1948 campaign funds, however, came from the JDC in the midst of the 1947 fall campaign. Extremely pessimistic about maintaining the 1946 and 1947 levels, and expecting no more than $\$ 90,000,000$ in actual donations no matter the goal, the Joint proposed that it receive one-half $(\$ 45,000,000)$, the UPA one-third $(\$ 30,000,000)$, and the USNA one-sixth $(\$ 15,000,000)$. Montor, responding for the UPA, agreed to the JDC terms on two 
conditions: a $\$ 250,000,0001948$ campaign, and everything over $\$ 90,000,000$ to the UPA! The JDC, not surprisingly, immediately rejected this counter-proposal. ${ }^{11}$

Montor's vision and chutzpah were vindicated, however, for he won from the JDC, eventually, a goal of $\$ 250,000,000$ (although less than $\$ 150,000,000$ was to be raised), and a distribution which gave the UPA 45 percent of the first $\$ 50,000,000$, 55 percent of the next $\$ 75,000,000$, and at least 75 percent of the remainder. "With this momentum, and the obvious shift of attention from decimated European Jewry in 1946 and 1947 to the birth of a new state, Israel, in 1948, the UPA allocation underwent even a more drastic shift. At the end of the 1948 campaign, the pre-campaign agreement proposed by the UPA--and reluctantly accepted by the JDC--for 1949 would give the UPA 60 percent of the first $\$ 50,000,000,70$ percent of the next $\$ 25,000,000$, and 75 percent of everything beyond that: Clearly the center of Jewish concern, and philanthropy, had shifted to Israel. 12

The 1948 spring campaigns were inaugurated with three significant events: the general chairman, Henry Morgenthau, Jr., assuming full-time responsibilities; the first UJA sponsored visit of Mrs. Goldlie (Golda) Myerson (Meir); and the UJA "Destiny Tour" to Europe and Palestine.

Morgenthau, who had already served as general chairman in 1947, and would do so again in 1949 and 1950 before moving to a similar capacity at Bonds for Israel (1950-1954), put his administrative experience to good use. Having served for more than a decade in the highest office ever held by a Jew in the United states, he lent his prestige and skills to the 1948 campaign in an unprecedented way. Prior to Morgenthau, three national or general chairmen--each of whom had a full-time profession outside of the UJA--jointly served the UJA more as honorary than working chairmen.

But Morgenthau devoted all his time and energies to the 1948 campaign. He was at work in his own office at the UJA headquarters (165 west $46 \mathrm{th}$ street) by 9:00 a.m. each morning and began each day with a conference of UJA department heads to review campaign problems and to provide Morgenthau with the opportunity to select the thorniest ones for himself. The rest of each day, until he left about 5:00 p.m., was spent on the telephone talking to communal leaders about forwaraing cash, accepting quotas, big gift problems, and much more; in meetings 
with community leaders who came to the UJA headquarters to meet personally with Morgenthau; and at his desk approving newspaper ads, radio scripts, speakers, and the like. Morgenthau, whose own devotion to Jewish philanthropy was recent but fervent, had a powerful impact on countless others, not only from his office but during his continual whirlwind fundraising throughout the land. 13

Morgenthau was most directly responsible for the tremendous success Mrs. Goldie Myerson (1898-1978), head of the political and security department of the Jewish Agency in Jerusalem, enjoyed during her month long campaign tour in February. She announced during her first appearance, in words which "paralyzed the normal noises of a great crowd" at the CJFWF conference in Chicago, that she "planned" (not "hoped") to return home at the end of the month with $\$ 50,000,000$ in cash, and "few personalities," Montor noted, "have ever receivd the ovation that greeted this woman." Nearly everywhere she spoke during her grueling speaking schedule, several big gift donors doubled their record-shattering 1947 gifts under the spell of her commitment and intensity. Representative of those she personally "doubled" were stanley sagner (Baltimore), from $\$ 15,000$ (1947) to $\$ 40,000$ (1948); Leonard Ratner (Cleveland) from $\$ 25,000$ to $\$ 50,000$; Abe and Harry Fine (Providence), Harry Fine (New York), Jacob Feldman (Dallas), and Charles Cohen (New York) from $\$ 50,000$ to $\$ 100,000$; and Y.D. Markson (Los Angeles) from $\$ 60,000$ to $\$ 125,000.14$

Mrs. Myerson did no private--only public--soliciting, and (accurately) recalled, more than twenty-five years later, the highlight of her tour: raising $\$ 1,500,000$ cash at a Miami hotel in one evening: When she departed at the end of the month, the UJA handed her a check for $\$ 35,000,000$, and expected $\$ 15,000,000$ more "very soon" as the result of what Morgenthau called "the most spectacular demonstration of a sense of responsibility that American Jewry has ever given." 15

Both the spring and fall campaigns were greatly aided by another of Montor's ingenious ideas. He arranged for a TWA plane, with the UJA "Star of Hope" emblazoned upon it, to pick up thirty-five key Jewish communal leaders in several U.S. cities (amidst great publicity), and for them to spend four weeks (February) on a "mission" of touring European and palestinian communities. The delegation even stopped at the vatican, where Pope Pius XII, in a special audience, blessed 
the $\$ 250,000,000$ "Destiny Drive." The men of the delegation, in the months following their return, became the organizers, speakers, and solicitors ("The Flying Caravan") at campaign functions throughout the country. They were one more link in the American Jewish communal chain which, after a decade of UJA existence (January 1939-December 1948), had raised more than $\$ 500,000,000$ for Jewish needs. 16

Montor saved for last, however, the most ambitious plan of his career--a vigorous challenge of the veteran zionist leadership and, more importantly, the familiar pattern of Jewish fundraising for Israel's needs. By the fall of 1948 Montor, who, we should recall, was both executive vice-chairman of the United Jewish Appeal and executive vice-president of the United palestine Appeal, had ready his plan to raise unprecedented sums from American Jewry. It would involve a major revolt within the UPA, the chief instrument of $z$ ionist fundraising in America, and would culminate in the virtual elimination of its traditional leadership (and, concomitantly, its power). In this "palace revolt" Montor would have the support not only of key zionist leaders he had carefully cultivated for years, but the vigorous council of Jewish Federations and Welfare Funds as well as Israeli leaders such as David Ben Gurion.

Montor launched his revolt on 10 september by submitting a letter to Israel Goldstein (b. 1896), UPA chairman, charging that the funas raised in the United states were being used "as a lever with which to change or dominate the social structure of palestinen and announcing both his immediate resignation as executive vice-president after twenty-two years of service to the UPA and, at the end of 1948, his resignation from the UJA.

Behind Montor's charge was a correct apprehension that American Zionist leaders hoped to push the Israeli leaders out of the World zionist executive and take control of the World zionist organization; and, given (according to Montor) their less than impressive record at educating American Jewry on the need for overseas giving, this was a possibility to be avoided. By the time the UPA executive committee had accepted the resignation ( 21 october), "condemning as baseless slurs" Montor's charges, Montor had organized nearly 100 Jewish communal leaders, representing. almost every major community welfare fund, into a committee of contributors and workers of the United Jewish Appeal poised to reorganize the UPA and 
demand at least 50 percent representation for local welfare funds in the new UPA. 17

Emanuel Neumann (1893-1980) and Abba Hillel Silver, zionist organization of America president and chairman of the American section of the Jewish Agency, respectively, alternated attacking the Montor group in the Anglo-Jewish and non-Jewish press, although Neumann, perhaps with some awareness of the strength of the committee, was far less stubborn than silver. For example, while announcing the UPA executive committee resolution of 14 october demanding Montor "retract in writing the specific allegations" in his september letter, he also noted that the same executive had "decided" to reorganize the UPA governing body in order to give the CJFWF one-third of the seats. Montor, with the support of the CJFWF, the organization which united all the local welfare funds, felt momentum had shifted to the revolt and rejected both the demand and the decision. 18

The Committee leadership consisted of distinguished, veteran, and powerful zionists and communal leaders, including several who held executive positions in local and national Jewish organizations. 19 When the UPA moved to implement its one-third decision, the $C C W$ announced ( 12 November) an Atlantic City conference of national Jewish leaders (11-12 December) to implement its own 1949 fundraising campaign for Israel. Ten days later, the executive committee of the committee for Progressive zionism, which included four former zOA presidents, threw its support to the $\mathrm{CCW}$ and called on the UPA to grant 50 percent representation to communal leaders, while a steady stream of Israeli leaders voiced their support for the CCW. Ben Gurion, for example, "was content to see the direction of UJA in the hands of non-zionist lay leaders and professional executives, rather than of ideologically-committed but party-affiliated zionists." 20

Hours before the conference delegates were to leave their homes for Atlantic City, the UPA and $\mathrm{CCW}$ hammered out an agreement ( 8 December)--in large part due to CJFWF conciliation-which in return for granting communal leaders 40 percent representation, the $\mathrm{CCW}$ agreed to cancel its conference. Nothing, however, was said about Montor until early January when an Emanuel Neumann-Abba Hillel Silver joint statement opposed the return of Henry Montor to fundraising leadership. 
Montor's support was far too strong, and his talents far too valuable, and when the UJA board of directors, after several weeks of seemingly endless and very bitter meetings, rehired the Morgenthau/Montor team to run the 1949 campaign (Montor threatened to raise hundreds (!) of millions of investment dollars through the Palestine Economic Corporation, and involve key UJA leaders in his efforts, if he did not return to the UJA), both Silver and Neumann resigned from the Executive of the Jewish Agency. They charged Montor with "serious and flagrant abuse of power . . spreading scandalous rumors and accusations," and "sowing dissension and distrust." This was, virtually, their last gasp, for silver faded from national leadership quickly while Neumann never again challenged the shift in American Jewish leadership, and Israeli fundraising, from zionists to local community leaders. To seal the triumph the UPA board of directors approved Montor's reappointment by a 52-0 vote (although thirty silver-Neumann supporters abstained) late in February. ${ }^{21}$

Montor, through these months of tension and strife, maintained a low public profile but made abundantly clear, in private correspondence, what was at stake. He desperately sought to shift power over Israel fundraising from zionist institutional leaders ( $Z O A$ and UPA) to American Jewish communal leaders, from zionists to all of American Jewry. And the reason was simple: hundreds, if not thousands, of affluent American Jews, he concluded, sympathetic to but not especially active in zionist activities, could be more easily persuaded to give generously to the UJA, and thus to Israel, by local community welfare funds than by zOA/UPA efforts. By shifting the burden of fundraising--ever since--from national zionist organizations to zionist and non-zionist local communal leaders, Montor understood the potential rewards in dollars for Israel. Ironically, by hammering away at some of the most dedicated and unselfish supporters of Israel (the NeumannSilver faction), Montor significantly improved the long-term prospects for Israeli financial support in America. 22 

CHAPTER 5

GENRY MONTOR'S FINAL 'IWO CAMPAIGNS: 1949-1950

AND THE JOSEPH J. SCHWARTZ YEARS: 1951-1955

After the annihilation of Europaan Jewry during World War II--a Jewry numbering more than nine million in 1939--its number stood at only 3,100,000, and hunareds of thousands of these Jews depended on government aid by friendiy nations, especialy the united states. Jews in Arab lands-faced with rising levels of nilitant nationalism and the reality of a Jewish state in the midst of an alien Arab world--were no better off. At the end of 1947 the Jewish population of Palestine numbered 630,000; four years later it had doubled. Jews came from the DP camps in western Germany, from Bulgaria, Poland, Romania, and (by special airlifts) from Yemen, Iraq, and Libya. This "ingathering" and "absorption" would not have been possible without considerable financial aid from the United states government and from diaspora Jews.

Henry Montor, after being rehired for the 1949 campaign, also directed the 1950 campaign before leaving the United Jewish Appeal for good and agreeing to guide the newly created Bond for Israel and to become both vice-president and chief executive of the American Financial and Development Corporation for Israel. During his final two years of UJA leadership, Montor solidified several aspects of UJA activities which he had either introduced or carefully directed.

First, he established a smoothly functioning national Committee on Community Quotas, with UJA (overseas) and CJFWF (local) representatives jointly establishing, in pre-campaign meetings, each community's campaign quota and, most importantly for the UJA, the percentage of that quota which would go directly to the UJA.

This was especially important to the UJA, for the percentage of income received by it from federation and welfare campaigns dropped precipitously between 1948 and 1949, i.e. local programs were generally maintained in 1949 while UJA percentages were cut in numerous places. American Jewry marched obediently through the "Year of Survival" (1947) and the "Year of Destiny" (1948) without faltering; but by the "Year of Deliverance" the pace had slowed. The European camps were closing; the Arabs were defeated; the immigrants on their 
way; and attention began to shift to home. The major victim of the 1949 decline was the UJA; indeed, several communities even retained more for local needs in 1949 than in 1948, although their campaign totals declined.

Montor responded quickly, vigorously, and with strength. Pre-campaign budgeting--approved by Montor forces at the annual UJA conference in November 1949--meant that the UJA demanded specific percentages of the 1950 total, and that if a local federation did not agree to the UJA quota (usually a sliding one) assigned it, the UJA could threaten to not participate in a joint campaign but to conduct an independent drive. Generally speaking, local funds were raised in the context of overseas needs--and with the generous support of the UJA campaign apparatus--and this served to intimidate many of the more than forty communities which, for the first time in 1950, agreed to set a minimum percentage as the UJA's share. ${ }^{1}$

Second, Montor reaffimed, and widely developed, card-calling. He argued that whether at "large metings, face-to-face interaction, or parlor meetings, the calling of cards is, by far, the fairest method of distributing the load of a campaign's responsibilities." Its alternative, "voluntary announcements of gifts," he strongly rejected, for big givers too easily "dodge their full burden" and there is "no pressure on the prospect." He urged, too, an aggressive approach to solicitation, demanding reliable knowledge of potential donor's means and the imposing of tough goals in personal solicitation. ${ }^{2}$

Third, he steadily persuaded the Joint Distribution Committee to spend more of its funds on Israeli immigrant absorpotion, and was given the major credit when the Joint entered into an agreement with the Jewish Agency and the government of Israel (October 1949) to assume a 50 percent share in one critical area of immigrant assistance. This was the creation of a new agency, Malben, to establish mental health programs, a TB hospital, nursing school, center for mentally retarded children, and villages for the aged and blind (the JDC undertook all of these tasks), while the government simultaneously would develop public facilities and housing near the Malben institutions so as not to leave these handicapped immigrants isolated. Within a year, however, the JDC took over the complete financing and administration of Malben, though its initial. contribution of about $\$ 10,000,000$ was not 
insignificant. During the nine months of 1949 prior to the agreement, thanks in large part to American Jewry's support, more than 200,000 Jews entered Israel, or more than one every single minute of the day and night. The JDC allocations to Malben greatly aided large numbers of those newcomers permanently crippled by the Holocaust years, and by 1958 the UJA could claim, with much pride, that Malben had cared for more than 100,000 immigrants. 3

Fourth, Montor had tremendous success in convincing nearly every major community to send its leadership to Israel for a first-hand look and high-level briefings prior to deliberating on the UJA quota. Given Israel's critical financial situation in the winters of 1949-50 and 1950-51 (below zero temperatures! combined with a nearly bankrupt economy, millions of dollars of crop damage, and massive immigrant absorption responsibilities), this technique maximized local commitments, and, therefore, UJA receipts, i.e., of the $\$ 103,000,000$ the UJA raised in 1946, $\$ 95,000,000$ came from welfare fund and federation drives.

At the height of the bad weather Montor still organized a two-week "mission" of seven non-Jewish newsmen--representing papers from Boston to Los Angeles-and forty-five Jewish communal leaders from Los Angeles (6), Dallas (5), Detroit (5), Chicago (4), Kansas City (3), Cleveland (3), Buffalo (3), Boston (3), and ten other cities. But this was not all; Montor also organized an Israeli mission to visit America. Numerous front-line veterans of the War for Independence, together with prominent Israeli officials and Jewish communal leaders, toured, aboard a seven train caravan, during a three week period in April 1949, 150 cities in forty states. A single car (half lounge, half pullman) of this "Caravan of Hope" left simultaneously from seven cities on 3 April, with special ceremonies to attract attention to the $\$ 250,000,000$ campaign. But perhaps Montor's greatest strength, in 1949-50 as in 1939, was the attention he gave to each and every local campaign. 4

In the fall of 1950 Boston launched the last large city campaign of Montor's administration. Its structure and organization typified countless other local campaigns--the heart of the UJA--and offers the opportunity for a close examination of the Jewish philanthropic mechanisms at work in the last months of Montor's UJA leadership. 
First, Boston's Combined Jewish Appeal goal of $\$ 7,680,000$ represented, as everywhere, a large increase over the 1949 campaign. Montor had urged every community in 1950 to approve a goal 20 percent greater than what was raised in the previous year, and Boston followed this advice precisely. Again, as in other communities, this sum represented a combination of the UJA quota (56 percent) and a local goal (44 percent). ${ }^{5}$

Second, Boston Jewry's campaign organization was divided into age, sex, and occupational/professional divisions, as Montor had suggested to campaign structures everywhere. A women's and a junior division were joined by such groups as beverage, house furnishings, real estate, and allied trades, women's apparel, insurance, food, men's apparel, shoe and leather, advertising, banking, chemicals, cleaners, curtains, as well as physicians, lawyers, accountants, dentists, and so on down through virtually every category of human endeavor.

Even within a division the numbers were often too large for the personal solicitation Montor had tried to introduce everywhere. Hence the women's apparel division, for example, had a "captain" and "co-captain" of each of the following sub-divisions: department stores, dry goods, furs, millinery, retail stores, women's wear, coats and belts, contractors, dresses, garment salesmen, sportswear, trimmings, and wholesale dresses. One of the keys to a campaign, Montor had argued for a decade (see chapter three) was in arranging public pledging or public solicitation (i.e., card-calling) dinners--after careful pre-dinner private solicitation by the captains, co-captains, and lieutenants--for each sub-division. This helps account for the more than 100 divisional luncheons or dinners/solicitations in the six weeks of the campaign, as the food division dinner/solicitation (27 September; Copley) yielded $\$ 264,000$, the men's apparel event (12 october; Somerset) $\$ 355,000$, and the real estate and allied trade division as well as beverage division dinner/solicitation raised $\$ 114,000$ and $\$ 104,000$ respectively. ${ }^{6}$

Third, Boston organized its fundraising around the Montor terminology: "advance gift," "big gift," or "kick-off" events. These functions, highlighted by the "keynote" dinner/solicitation ( 10 September; Statler) for 800 with Abraham Sachar, Brandeis university president, providing the solicitation address, and the big gift dinner/solicitation (18 September; statler) for seventy with Aubrey (Abba) Eban doing 
the honors, raised more than 40 percent of the eventual $\$ 5,700,000$. Nevertheless, efforts to raise funds from small givers, i.e., those not solicited as members of a division, were significant. 7,500 volunteer men and 3,200 volunteer women marched to thousands of Jewish homes in twenty-eight cities and towns of Greater Boston on "men's day" ( 8 october) and "women's day" ( 9 october) in a massive house to house solicitation. And organizing a fundraising event knew no age limits: Barbara (10) and Roger (8) Goldstein of Babcock street in Brookline held a kiddie carnival, on 12 october, and despite the rain were able to send several dollars directly to the UJA. 7

By the end of 1950, perhaps Montor really believed, as he wrote to a friend, that he had accomplished all he could at the UJA, or perhaps it was the challenge of directing Bonds for Israel that convinced him to resign from the UJA. Whatever the reason, his successor, Joseph J. Schwartz, was surely correct when he noted that "Montor's genius served as the foundation stone for the success of the United Jewish Appeal." And Schwartz's successor, Herbert Friedman, spoke of Montor in similar terms:

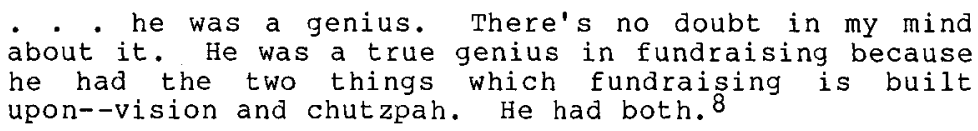

Schwartz (1899-1975), a Russian immigrant who came to the United states in 1907, received his (orthodox) rabbinic ordination in 1922 and his Ph.D. in semitic languages at Yale in 1927, served a congregation in New York City and taught at Cairo University and at Long Island University (the latter, while working part-time at the Federation of Jewish Charities in New York City) before beginning, in 1931, a full-time career in Jewish philanthropy. ${ }^{9}$

Dr. Schwartz (his closest friends called him "Packy") served as executive director of the Brooklyn Federation of Jewish Charities (1931-1939), as chairman of the European executive council of the JDC (1940-1949), and as the JDC's director-general (1950-1951) before succeeding Montor. In this latter capacity, he skillfully directed the UJA financed operation "Magic Carpet" rescue of nearly 50,000 Yemenite Jews. For most, their redemption began with a six week, 200 mile trek from Yemen, through various sultanates, to the British protectorate and Yemenite port city of Aden, and 
continued, on skymaster $\mathrm{C}-54 \mathrm{~s}$ and $\mathrm{DC}-4 \mathrm{~s}$ filled to three times their normal capacity, to the new state of Israel.

"Joe Schwartz was a legend," Herbert Friedman recalled; "he was a hero; he could do no wrong; he came out of that legendary period of fighting the Nazis; he was one of the kindest, most ful1-hearted, loving Jews you'1l ever meet." Schwartz brought to the UJA an especially strong understanding of European Jewry at a time, alas, when this Jewry was no more, and when all international Jewish welfare organizations had either withdrawn from or been asked to leave eastern Europe. Furthermore, during Montor's last year the UJA campaign goal reached the highest ever; but each year between 1951 and 1955, the schwartz years, the campaign goal declined and the campaign dollars diminished. By the time Schwartz had served $41 / 2$ years, both he and the UJA were pleased to see him leave. 10

The first major fundraising event to take place after Schwartz came into office was an enormous success. 500 big givers from across the nation kicked-off the 1951 campaign in Miami (18 February) by giving $\$ 10,150,000$, the highest ever at a single meeting. Sixty-seven pledges, at this incredible evening, were over $\$ 25,000$; nevertheless, the UJA only raised about $\$ 85,000,000$ in 1951--much less than half the campaign goal--and in spite of the public attention devoted to the massive emigration of Iraq's Jews. ${ }^{11}$

1952 was more disappointing still, for despite $\$ 11,341,000$ at the Miami Beach kick-off and a $\$ 150,000,000$ goal, the top ten Jewish communities in the United States raised 9 percent less in 1952 than in 1951 (the UJA received 13 percent less), while the next forty-nine in size raised 12 percent less (the UJA receiving 18 percent less). Schwartz tried, during these years, to persuade local communities to guarantee the UJA quota--despite lower totals--but with little vigor and to no avail.

Schwartz was absolutely soft, not decisive; he couldn't lead a fight; he couldn't do anything. He was too kind and too nice and too soft and too gentle.

In the fights over how much the UJA should get and how much the local community should get, schwartz lost every fight. He didn't want to fight; he didn't like to fight. His attitude used to be "ah Herb, so Los Angeles wants to take another five percent for themselves--why make a fight?"

The result was, as Table 5:1 reveals, that many communities provided for local needs, in the face of lower revenues, at the 
expense of the UJA and the hundreds of thousands of Jewish immigrants pouring into Israel. ${ }^{12}$

1953 too got off to a promising start: the kick-off yielded a whopping $\$ 14,100,000--20$ percent more than in 1952 even though the 1953 quota was lower than that of 1952; the special gifts meeting in Cleveland yielded $\$ 2,062,000--\$ 500,000$ more than ever before and 14 percent over 1952; and Baltimore, Detroit, Los Angeles, and Newark brought in comparable increases. And yet, the 1952 and 1953 campaigns, together, yielded less than $\$ 150,000,0000^{13}$

Even with nearly 80 percent of the 1952 and 1953 UJA totals piped to Israel through the United Israel Appeal (the successor to the UPA) and the JDC's Israel programs, the UJA came nowhere near filling its budget requests. Early in 1954, the UJA thus decided to float a five-year, $\$ 75,000,000$, loan--in addition to the normal campaign--in order to consolidate some of Israel's short-term debts. The loan would be retired by the UJA paying 20 percent of the principal (plus interest) each year for five years. There was little difficulty in raising this amount: 112 communities pledged $\$ 65,800,000$ of the $\$ 75,000,000$ quickly. $\$ 30,000,000$ in cash was rapidly available to send to the UJA, and $\$ 12,000,000$ more followed soon. New York, with $\$ 20,000,000$, led the way, but Philadelphia, Cleveland, Boston, and San Francisco, with $\$ 3.3,2.5,2.25$, and 1.0 million respectively, made significant contribitions. By June, 80 percent of the loan had been sent in cash to Israel. 14

Schwartz's last year too, 1955, started with a bang: a testimonial dinner for Edward M. M. Warburg (b. 1908) in New York on 22 January raised $\$ 10,150,000$, and the Miami Beach evening in March was, again, record shattering, as the $\$ 17,650,000$ surpassed by more than $\$ 3,500,000$ the 1953 record. But the spring campaigns moved so slowly that by June schwartz had resigned and his successor had been installed. Despite his announcement in January at the Warburg dinner that he would serve one more year, the board of directors had long since decided to change leadership and Herbert friedman was their choice.

Already in 1952, one year after hiring schwartz, Warburg and Rosenwald came to see me. . . to ask me to take over the UJA. I said no. They came back to me in 154. . . and pleaded with me. I made an arrangement with them to enter into the job in June of 1955. 
The UJA leadership, reflecting upon Montor's years of success, felt convinced that the top executive made the difference; they failed to understand that record levels of giving could hardly be sustained year after year once the drama of Israel's war of Independence yielded to the prosaic refugee absorption. Schwartz himself offered no opposition--perhaps because Montor offered him a job with Israel Bonds and because, as Herbert Friedman explains:

It was not a job for him because this was a fighting job and he was not a fighter. He didn't like it and he wanted to get out. 15 


\author{
CHAPTER 6 \\ THE "BIG GIVER" \\ Jewish fundraising is a game; a game \\ played for big money. \\ Irving Bernstein, June 1980
}

The United Jewish Appeal, of course, was not without its critics during the 1940s and 1950s. Sometimes even the strongest allies of American Jewish fundraising expressed doubts, publicly and privately, about various aspects of the UJA machinery. One of the most gentle, and yet prescient, critiques came from Wallace Markfield (b. 1926)--the author of novels, short-stories, and essays--and satirizes the bureaucracy of the UJA and its affiliates.

Markfield is sensitive to a number of developments in Jewish philanthropic activity. He notes the variety of groupings and sub-groupings which campaign leaders developed, the new nomenclature for tactical operations which came into play, and the fact that professionals provided most of the campaign promotion in the name of lay leaders. He also reminds us not only of "big-name," effective speakers, who have been "on the scene" and who provide "kick-off" dinners wth inspiration, accurate quotes, and relevant examples, as well as imaginative promotion, stirring literature, and other ideas courtesy of the UJA, but that local honorees, the "stuff" of many campaign events, get their turn too, and that often the professionals cannot prepare remarks for them.

Most of all, Markfield understands the growing importance of the "big giver," a man who as a result of increasingly being made to feel that he is a power and having been generously rewarded with autographed pictures of Israel's Prime Minister or similar momentos becomes rather immodest. When Lionel Resnick eventually derides the system which honors him ("Talmud Torah swimming pool"), wrongly cites a rabbinic quotation ("magnificent biblical injunction"), tells a long and meaningless story, and insults his father with an absurd quote ("Jewish heart. . under the Cossack's uniform")--all with the best intentions--Markfield touches a central nerve of Jewish giving. 
DRAFT: INVITATION TO LARCHDALE CONTRIBUTORS

Dear ............

This is a special occasion.

For on May 28th, at the Big Lawn Country Club, we of the Larchdale Jewish community will have the chance to pay well deserved and long overdue tribute to Lionel E. Resnick. He's president of Pru Frock Co., and a man who's given so much of himself to so many civic and philanthropic causes we couldn't begin to list them in so short a space.

At the same time, we'll be able to reaffirm our support of the Council for the comfort of the Jewish Lonely in Medium-Sized Communities, where Mr. Resnick has done such a magnificent job as honorary vice-chairman of the Northeast Region. For this year, CCJL must raise $\$ 2,469,000$ more than last year--to meet the cry for increased staff, increased services.

So please, while it's before you, send along the enclosed reservation cared telling us to save a place. And we'll be looking forward to the pleasure of lifting a glass with you in Lionel's honor, come May 28th.

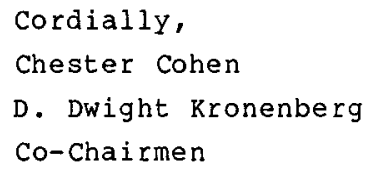

FOR IMMEDIATE RELEASE

Lionel E. Resnick, president of Pru Frock Co., and long prominent in Larchdale's civic and philanthropic endeavors, will be honored at a special dinner of the Council for the Comfort of the Jewish Lonely in Medium-Sized Communities (CCJL), to be held on May 28th, at Big Lawn Country Club, it was announced by Chester Cohen and D. Dwight Kronenberg, co-chairman of the affair.

The Council for the comfort of the Jewish Lonely in Medium-sized Communities seeks to retain, rehabilitate, and relocate those Jews in cities of less than 100,000 population who, within a three-mile area, have social, communal and religious ties with no more than four fellow-Jews.

Mr. Resnick, whose firm is one of the largest house-dress manufacturing and merchandising organizations in the country, is also a director of the National House-Dress Manufacturer's Association. He has achieved wide recognition as an 
outstanding leader in various communal endeavors. Honorary vice-president of CCJL's Northeast Region, and vice-chairman of the National Council of the Board of Governors of the Jewish Capital Fund Drive, he is also a trustee of the Larchdale Jewish Community Center and a founder of the Big Lawn country club. He is married and has two daughters, Sharon, seventeen and Rita, twelve.

DRAFT: PAGE TWO OF LARCHDALE INVITATION

Withhold not help from the needy

When it is in your power to render it

Say not to your neighbor, "Go and come again;

Tomorrow I will give" when you have it beside you...

Book of Proverbs

It is in this traditional spirit of Jewish philanthrophy that we of Larchdale gather to render tribute to one amongst us who has served his neighbors, his community and his fellow-men with a devotion that few could match.

Good neighbor, earnest and generous worker for a host of humanitarian causes, Lionel E. Resnick has been an unfailing source of leadership and devotion over the years. Every great charitable and communal endeavor has derived the benefits of his dynamic leadership, his vision and his warm heart.

We, his friends and neighbors in Larchdale, take the opportunity of our annual dinner on behalf of the Council for the Confort of the Jewish Lonely in Medium-Sized Comunities to honor him. It is a deep pleasure to come together and wish him many, many more years of leadership and honor.

DRAFT: FOLLOW-UP ON LARCHDALE MAILING

Dear ................

I know you've already received a letter about our concil for the Comfort of the Jewish Lonely in Medium-sized Communities' dinner in honor of Lionel E. Resnick. As co-chairman of the event, however, I couldn't help but add my own personal invitation.

For Lione1--or "Labey," as he likes to be called--is just about one of the grandest guys around. Whenever a worthy cause has had need of a helping hand, of vision and dedicated leadership, "Labey" has spared neither time, nor energy, nor worldly goods. It seems to me that you and $I$ and every other member of the Larchdale Jewish community can do no less than 
make this evening in his honor one he'll remember for a long, long time to come.

Many, many thanks. And please do this hard-working co-chairman the favor of sending along the enclosed reservation as quickly as possible.

Cordially,

Chester Cohen

\section{FOR IMMEDIATE RELEASE}

Reservations for Larchale's Council for the Comfort of the Jewish Lonely in Medium-Sized Communities (CCJL) dnner in honor of Lionel E. Resnick are expected to top the two hundred mark, it was announced by Chester Cohen and D. Dwight Kronenberg, co-chairmen of the affair.

With three weeks remaining for the Big Lawn Country club event, reservations have already passed the one hundred and forty peak, and the pace is expected to intensify within the next few days as the dinner committee gathers momentum for its clean-up phase.

Messrs. Cohen and Kronenberg cited this response as "heart-warming evidence of the esteem and admiration in which Lionel E. Resnick is held by his friends and associates." They went on to say that "it is indeed fitting for us to tender tribute to one amongst us whose life and works symbolize the very highest ideals and aspirations of the American Jewish community."

The Council for the comfort of the Jewish lonely in Medium-Sized Communities seeks to retrain, rehabilitate and relocate those Jews in cities of less than 100,000 population who, within a three-mile area, have social, commanal and religious ties with no more than four fellow-Jews.

This year, CCJL seeks a total of $\$ 12,490,000--\$ 2,469,000$ more than was raised last year--to meet the pressing demands for increased staff and increaed services.

DRAFT: FOLLOW-UP TO NON-RESPONDERS

Dear .................

This is the kind of letter we hoped we wouldn't have to write.

For we were certain yours would be amongst the first reservations to our Council for the comfort of the Jewish Lonely in Medium-Sized Communities' dinner in honor of Lionel 
E. Resnick. But, with only a few short weeks remaining, there's still no word from you.

Sure, we know it's all too natural to put these matters off till the very last possible minute. Please, though, won't you soothe the anxieties of these hard-working chairmen by sending out your reservations now. You couldn't ask for a more worthy cause, a finer guest of honor, or a better chance to join in a night of good fellowship and philanthropy.

our thanks, and we'll be awaiting the pleasure of breaking bread with you, come May 28 th.

$$
\begin{aligned}
& \text { Cordially, } \\
& \text { Chester Cohen } \\
& \text { D. Dwight Kronenberg } \\
& \text { Co-Chairmen }
\end{aligned}
$$

DRAFT: $\begin{aligned} & \text { SOLICITATION OF MEMBERS OF NATIONAL HOUSEDRESS } \\ & \text { ASSOCIATION }\end{aligned}$ Dear .................

"What's in a name?" the Bard of Avon asked.

Well, a name can mean many things to many men. But to those of us who make up the National Housedress Association, the name "Labey" means integrity, vision and leadership. It means Lionel E. Resnick, of Pru Frock Co., the kind of guy it's been a pleasure to deal with over the years, the philanthropic pace-setter of our industry.

You'll be glad to know that on May 28th, the Council for the Comfort of the Jewish Lonely in Medium-Sized Communities will be honoring him. This is something all of us should be proud of--and part of. That's why I've taken the liberty of enclosing five tickets at $\$ 100$ each, which would represent your contribution to CCJL, your part in what promises to be a moving, memorable evening. It would mean a great deal to all of us--and I know "Labey" would be deeply moved--if you took advantage of this opportunity to help answer the calls for help from those who have known loneliness far too long, from those who need help in time, in time of need.

It will take only a moment to write out your check--but the effects will be everlasting.

Sincerely,

Chester Cohen

D. Dwight Kronenberg

Co-Chairman 
FOR IMMEDIATE RELEASE TO WOMENS WEAR TRADE PAPERS AND JOURNALS

Lionel E. Resnick, guiding genius of Pru Frock Co., will caise his millionth philanthropic dollar on Thursday, May 28th, on behalf of the Council for the comfort of the Jewish Lonely in Medium-Sized Communities.

The occasion will be a dinner in his honor at Larchdale's Big Lawn Country Club, where Mr. Resnick is being lauded for "outstanding and meritorious service in communal and philanthropic affairs."

Earlier that day, Mr. Resnick will make another significant stride--this time on the fashion front, when he inaugurates his new Pre-Natal line of house dresses, house coats and brunch coats. Pre-Natals, according to Mr. Resnick, are designed to fill the need of a market too long neglected. "Now, for the first time," he declared, "the young matron who expects to be expecting can look forward to her period of expansion." Lastex waists and bodices are specially designed to meet the pressure of the times.

\section{FOR IMMEDIATE RELEASE}

Cass Dworkin, executive vice-president of the Allied Jewish Suburban Council, will be principal speaker at Larchdale's Council for the Comfort of the Jewish Lonely in Medium-Sized Communities' dinner in honor of Lionel E. Resnick, to be held on May $28 \mathrm{th}$, at the Big Lawn Country Club.

The announcement was made by $D$. Dwight Kronenberg, of $D$. Dwight Kronenberg Realtors, and Chester Cohen, of Rejuvenay Footwear Co., co-chairmen of the affair.

Mr. Dworkin, one of the nation's outstanding authorities on inpatient programs for the Jewish child and the planning of old age services for the small and intermediate Jewish community, has taught at the Everyman School and the Caseworker's Summer Institute. He is the author of numerous widely-hailed books and pamphlets, including "New Designs in Geriatric Rehabilitation," "Bed Capacity and the Jewish Hospital" and "The Long View in Jewish Social Welfare Planning." He has recently returned from a tour of Israeli Day Care Centers, made at the invitation of the government.

The Council for the Comfort of the Jewish Lonely in Medium-Sized Communities seeks to retrain, rehabilitate and relocate those Jews in cities of less than 100,000 population 
who, within a three mile area, have social, communal and religious ties with no more than four fellow-Jews.

This year, CCJL seeks a total of $\$ 12,490,000--\$ 2,469,000$ more than was raised last year--to meet the demands for increased staff and increased services.

DRAFT: FOLLOW-UP FROM GUEST OF HONOR

Dear ..............

This is an unusual letter. . . unusual, because it's not customary for a guest of honor to invite people to attend his own testimonial dinner.

of course, I would consider it a great privilege to have you take part in Larchdale's annual Council for the Comfort of the Jewish Lonely in Medium-Sized Communities dinner, on May 28th, at the Big Lawn Country club.

But I'm writing this letter for a much more important reason. I'm writing because I'm convinced that our own CCJL is doing work of utmost significance to you, me, our families and fellow Jews. It is helping make sure that no Jew will ever know the pangs of loneliness, the terrors and tensions of those who must wander far afield for social, religious and communal discourse.

For these reasons, I urge you to make your reservations now for our dinner at Big Lawn on May 28th. A special feature of our evening will be an address by Cass Dworkin, executive vice-president of the Allied Jewish Suburban Council, a truly exciting, dynamic figure, and a speaker of note. All in all, I think I can promise you the kind of evening it would be a shame to miss.

Please fill out the enclosed reservation card letting me know you will come--not in my honor--but on your own behalf, as an American Jew eager to make certan that in days to come no Jew shall be without a neighbor.

\section{Sincerely, \\ Lionel E. Resnick}

DRAFT: TO DINNER COMMITTEE:

Dear ..................

We've just had a brainstorm:

The other day, sharing some coffee and conversation, it suddenly dawned upon Chester and myself that it would be a 
splendid, fitting thing if we--you, I and the rest of our hard-working Committee--did something offbeat and special for "Labey."

Here's what we had in mind. . . Over and above the silver scroll we're presenting to "Labey," let's get together and give him something that will be a personal memento of the evening, a little gift that will come as a delighteul surprise. And so we turn to you, in the hope that you'll pitch in and help us purchase a lovely Patek-Phillipe watch for "Labey." Your share would come to $\$ 30$, which includes the engraver's fee. And I don't think we need tell you how deeply touched "Labey" would be at such a warm-hearted gesture.

Cordially,

Dwight and Chester

FOR IMMEDIATE RELEASE

A record turn-out of prominent leaders and businessmen is expected for the Larchdale council for the comfort of the Jewish Lonely in Medium-Sized Communities' dinner in honor of Lionel E. Resnick, it was announced by D. Dwight Kronenberg and Chester Cohen, co-chairmen.

With only two days remaining till the Big Lawn Country Club event, Messrs. Kronnenberg and Cohen disclosed that "reservations have topped the two hundred mark, and we fully expect this to be the most successful affair Larchdale has ever held on behalf of CCJL."

The two co-chairmen went on to say that the dinner "will afford Lionel E. Resnick's many friends and associates the opportunity of acknowledging publicly the respect and esteem in which he is held by all who know him." They pointed out that the affair, which features Cass Dworkin, executive vice-president of the Allied Jewish Suburban Council, as principal speaker, will be climaxed by the presentation of a special silver scroll to Mr. Resnick for his "contribution to the ideals and ethics of American Jewish communal life."

The Council for the Comfort of the Jewish Lonely in Medium-Sized Communities seeks to retrain, rehabilitate and relocate those Jews in cities of less than 100,000 population who, within a three mile area, have social, communal and religious ties with no more than four fellow-Jews. 
This year, CCJL seeks a total of $\$ 12,490,000-\infty \$ 2,469,000$ more than was raised last year--to meet the demands for increased staff and increased services.

DRAFT: AGENDA FOR LARCHDALE CCJL DINNER, BIG LAWN COUNTRY CLUB

$6: 30--7: 00$

Cocktails in palm Lounge

$7: 00--7: 45$

Dinner

$7: 45--7: 55$

"Right now, to be honest, I feel sort of like the sultan's son, who inherited his father's harem. I know what I'm supposed to do--but I'm not sure I know where to begin.

"At any rate, let me begin from the beginning, by telling you how proud--and flattered--I am to see the splendid turn-out this evening. On behalf of myself, my dinner committee--which did such a great, great job, each and every one--and my hardworking, hard-driving co-chairman, D. Dwight Kronenberg, I bid you welcome.

"We have a tremendously interesting evening planned for you, and I promise you to keep my remarks on the short side.

"There's just one thing, though, that comes to mind, a thought I'd like to share with you. An impressive attendance such as this one makes me hearken back, nostalgically, to our earlier days, some eight, ten years back, when we were getting this cause underway. I'm proud--and it's a feeling I know you all share--at the way we've grown, at the way we've been taking a consistently greater and greater share of responsibility in this effort which means so much to each and every one of us.

"The man I'm about to introduce is the kind of guy that calls forth mighty adjectives from those who've been privileged to work with him--dynamic, forceful, brilliant--all of them will deserved. Most of you know him as a mighty force in our community, a man we've turned to over and over again for leadership, for inspiration, for the kind of direction that can take a philanthropic dream and turn it into the kind of reality that brings relief to the sick, the needy and distressed. 
"Gentlemen, it's my pleasure and privilege to give you now as fine a co-chairman as anyone ever had--D. Dwight Kronenberg."

$7: 55--8: 08$ approximately

D. Dwight Kronenberg:

"A wonderful introduction, Chester. And, like you, I promise to keep an eye on the clock now, for I want to get this wonderful evening under way as swiftly as possible.

It's my task to do the honors for our speaker tonight. This is no easy assignment, for there's much one could and should say about a career so long and distinguished. I like to think of him as a trail-blazer, the Daniel Boone of the social welfare field--or, as he's often called, MR. JEWISH COMMUNAL SERVICE.

"And I'll say this, too. The Jewish child, whether tot or teenager, who looks for wise and sober counsel, for a way out of what seem to be baffling problems. . . the Jewish aged, who seek to spend their declining years, those years of which the great poet Browning spoke when he wrote 'Grow old along with me/The best is yet to be/The last of life/For which the first was made. . . .'' The Jewish chronically ill, who once upon a time sought, alas, in vain, for special care, special treatment - all these have our distinguished speaker to thank for help in time. . . in time of need.

"It is right and fitting now that I turn the dais over to Cass Dworkin."

8:08--8:43 approximately

Cass Dworkins speaks.

8:43--9:15 approximately

Chester Cohen:

"Our thanks, Cass, for making so crystal clear the grave problems that confront our council for the comfort of the Jewish Lonely in Medium-sized Communities during the year ahead. We know where we stand now, we know what we must do to preserve and extend those precious things for which our cause stands. We know that we must search our hearts, examine our consciences and open our purses, so that CCJL will have the means, the resources to fulfill its tremendous responsibilities.

"My friends, I shall call your cards now and await the announcement of your pledges. And let us strive, one and all, 
to find in ourselves the capacity for increased giving--even as the needs of our agency have increased."

(Cara calling begins at this point. Make sure to interject little enthusiastic phrases . - . i.e., "A twenty percent increase, Larry? That's swell!. . . Three hundred in your wife's name, Max? Score one for the distaff side!. . . Four fifty from your firm? Nice going, Arnold!")

$9: 15--9: 23$

D. Dwight Kronenberg:

"Before I begin, I want to thank my Committee for extending to me the honor of acting as their spokesman in presenting our Council for the Comfort of the Jewish Lonely in Medium-Sized Communities Award to Lione1 E. Resnick.

"I am grateful for this privilege because of my high personal regard for our guest of honor. For 'Labey' is not only a co-worker in our philanthropic vineyard, but also a very, very dear friend.

"The keynote of our dinner--the cause for which we are assembled tonight--is the concern for our fellow man, for the heritage which has made us a Jewish community proud of its accomplishments, of its contributions to the welfare of our own brethren and our fellow Americans.

"To put it succinctly: 'Labey' makes the grade.

"And, at the risk of embarrassing him further, I want to point out that we are afforded the opportunity to express publicly what many of us have been saying privately for a long, long time.

"For doing so much for so many, 'Labey,' and just for being a swell guy, we all thank you.

"I will now read the citation on this handsome scroll:

'The Larchdale Jewish Community, gathered here at the Big Lawn country club on this 28 th day of May on behalf of the Council for the Comfort of the Jewish Lonely in Medium-Sized Communities, confers this citation upon Lionel E. Resnick in everlasting testament of his untiring efforts to further those principles and programs which epitomize the highest and most ennobling traditions of our people. His charity, his good will, and his inspirational leadership have won for him the respect and admiration of all those to whom the concern of man for man is a sacred trust.' (Allow time here for applause.) 
"And you just stand there for a moment, 'Labey' . . because you don't get away that easily. A bunch of us-your friends and co-workers--decided to get together and give you some tangible evidence of our deep feeling for all you've done over the years. Here it is, 'Labey,' (Holds watch up for the audience.) And may I say that I hope, in years to come, it will keep time with the fidelity and punctiliousness that have always marked your own days and ways."

$9: 23--9: 49$

Lionel E. Resnick:

"When I heard all those fine words that were said and written about me I began to get nervous. I expected, even as I stood upon this lovely dais, to have someone tap me on the shoulder, take my scroll and say, 'Sorry fellow, wrong guy:' (Allow moment for laughter.)

"Seriously, though, I want you, one and all, to know how profoundly moved $I$ am by this splendid tribute. And the watch--well, all I can say is that I'll always treasure it, not only as the thing of beauty it happens to be, but as a token of an evening I will remember for the rest of my life.

"You know, every time my daughter comes home from college she scolds me. . . She says to me, 'Daddy, you get up so early in the morning, you're in the place before anyone else, you put in such terrible hours and still, comes the evening and we never, never get to see you. You're always rushing off to this dinner or that dinner, you're having an organizational meeting, a committee meeting or a special gifts meeting, a this meeting or a that meeting.'

"Well, what can I say? How does one answer such an accusation? To the charge of being what they call a congenital do-gooder I must plead, alas, guilty. When all is said and done, maybe I should spare myself a little more, take it easier, spend a little more time with the family, let a few of you younger people come into your own and stop giving so much of myself to so many causes. But human nature being human nature, I suppose this old work-horse, this lay leader, will just keep himself in the harness of philanthropy till that day comes--as it must to all of us--when the Great Card Caller asks for full payment on outstanding pledges.

"What it boils down to, I guess, is that I'm the last of an old breed--one of those who, in his own small way, has tried to 
heed that magnificent Biblical injunction: 'All Jews are responsible for one another.'

"That's how it's always been with me. Standing here, now, I can't help but think back, back, to a long time ago, when I started out with a pair of rusty, second-hand shears and a cutter. And I want to tell you, that was a cutter! He suffered from, if you'll forgive the aside and pardon the expression, a hernia. Which stopped him, naturally, from lifting, from pulling, from doing too much heavy work. Somehow, though, he was able to summon up enough strength and energy to sneak the pieces of yard-goods home every night and the little bundles of string and wrapping paper. What one human being did with so much string is beyond me, even to this day, some thirty, thirty-five years later!

"The point is that in those days we didn't know too much from fund raising and fundraisers, we didn't have it all so nice and systematized: it wasn't such a science. Nobody had to send you a fancy letter or an engraved invitation or a reminder card to let you know that you had certain obligations and responsibilities to the less fortunate. That's how we were taught, that's how we were brought up. And we gave, believe me, we gave--back to the days when a dollar was a dollar, when the government didn't encourage with so many exemptions and they didn't pressure you every Monday and Thursday to tell you that Israel needs a navy or the Talmud Torah has got to get itself a new wing where the kids can have a swim. Which is not to say that Israel, may it prosper and be blessed in the world of nations, doesn't need a navy, or that the kids shouldn't have a swimming pool; if the Catholic schools can build them, we can also build them. Only, since I'm being blunt and outspoken at the moment, I might as well say that for the 1 ife of me, I can't see why, six weeks ago, to help irrigate the orange groves in the Negev, it was absolutely necessary to hold poetry readings and charge fifteen dollars. An old-fashioned raffle, with an old-fashioned Caddy still brings in more than a hundred poems and a hundred poets.

"When I say this, I mean in no sense to carp or chastise. As a matter of fact, I'll let you all in on a little secret: I am something of a poet myself. At least, that's what Fortune wrote a few months ago. 'A poet of business enterprise, Lionel E. Resnick hearkens back to the merchant princes of old, who helped usher in the age of double standards and double entry 
bookkeeping. To the housedress, once consigned to the humblest order in the hierarchy of fashion, Resnick has brought $z$ ip and zest, a flair for design and an uncanny gift for prophecy. Few in the field know better than he when the time is ripe to usher in a line of buttons and bows, when to raise a hem or lower a neck.'

"If I tell you now that Fortune is much too kind to me, it's not out of false modesty. Because, basically, it hasn't been so much a question of 'poetry' or 'zip' or 'zest' or 'buttons' or 'bows.' They don't mention, for example, how three years ago I took such a terrible walloping when I put out a line with sequins. I have my talents and abilities, I don't deny. Still, more than most men, I've had my share of luck. on Seventh Avenue they say, 'Resnick... he could buy a cemetery plot today and tomorrow they'd build a turnpike right through it...'.'

"To give you an illustration. . . Three summers ago my wife, believing, maybe, that we had it too easy, decided all of a sudden that the mountains weren't good enough for her, the beaches weren't good enough for her, and that American didn't have enough monuments. So, off we go to Europe, with--so help me God--a whole suitcase stuffed with Kleenex, aspirin and various other articles of intimate and not-so-intimate nature which this one and that one claims is impossible to buy abroad.

"We spend a week or so in England, and I'll guarantee that was the dullest, dreariest week in my life. Wherever you go, it seemed to me, you got a whiff of cheap cooking greens and fats. And it was impossible, absolutely impossible to get a decent meal. You stop in somewhere for a sandwich, you're starved, you haven't had a thing in your mouth since breakfast and they have the gall to put down in front of you one slice of bread with the crust trimmed off, a snip of lettuce that dates back to before they had kings, and one greasy sardine. And, all this, mind you, without a napkin, without a glass of water. All in all, it's a wonder of wonders that they didn't lose their Empire a long time before.

"Paris, of course, was a little better when it came to food. Still, something bothered me. Somewhere, I was lacking. I couldn't figure it out, till one day, finally, finally, it dawns on me. I'm wandering around near the Louvre waiting for my wife, I have a couple of hours to kill, and how it happened I don't know--when I tell it to people they call me 
crazy--but I smelled something like the smell of delicatessen in the air. Whether corned beef or what I couldn't tell you. It could have been in my imagination. But I realized that no matter what, no matter how, the day was not going to pass by until Resnick had gotten himself a pastrami sandwich.

"Of course, when you're in the midale of paris, when you don't know the city and you don't know the people and you don't know more than ten words in the language, it is no easy task to get hold of a pastrami sandwich. I don't lose my head, however, I don't get panicky. Somebody, later on, told me I should have called the American Embassy, but who thinks of those things? And then, what I referred to before, the Resnick luck, begins to go into operation.

"You see, I begin to study the faces of everyone who passes. I watch and I observe. I let one go by, I let another go by, I let a half dozen go by. Then, finally, finally, a man passes with a beret and a cigarette hanging out of his mouth, a pleasant faced little chap, neat as a pin. To look at him, a typical Frenchman. And what it is I don't know. . maybe it's as my father used to claim, that 'one Jewish heart feels another, even under the Cossack's uniform' . . but something told me to go up to him, something told me to speak:

"I don't want to make a safari out of a trip to a men's room, so let me cut it short by simply telling you that this gentleman was not only Jewish--and he spoke a Yiddish that was a pleasure to hear--but he took me for one of the greatest sandwiches I have ever eaten in my life.

"Anyway, here I stand now with a nice new watch on my wrist and a beautiful scroll in my hands. The latter will go right into a prominent place in my den and in days to come I'll point to it with pride and pleasure.

"I want you to know, however, that I consider as the main tribute, the real and most touching tribute, the fact that you have all seen fit to once again stand four-square behind our cause, so that it may continue its great work unhampered and unchecked. To realize that $I$, in my own small way, have had a share in this is true and lasting satisfaction indeed.

"So let me conclude, then, sincerely, humbly, with the one word that springs unchecked from the bottom of my heart . . .

"Thanks!" 1 

CHAPTER 7

THE VIEW FROM THE TOP:

HERBERT FRIEDMAN'S REIGN: 1956-1969

\begin{abstract}
The goals of the UJA are to assure the physical survival of every Jew in the world threatened by oppression or need, to assure spiritual liberty and freedom for Jews through programs of migration, and to support the growth of free Jewish communities. Herbert Friedman, 1964

Every time I made an operation, I would be the director, because I never trusted anybody with details. Herbert Friedman, 1976
\end{abstract}

This decade and a half of United Jewish Appeal fundraising was played out against a background of widespread Jewish emigration from North Africa, the Middle East, and eastern Europe; the enormous challenges presented to Israel in attempting to absorb sizeable numbers of impoverished immigrants; the Six Day War (see chapter eight); and the many Jews all over the world still dependent on UJA welfare allocations. A significant number of developments within the UJA's organizational structure served to maximize efforts to respond to these challenges.

The period began with an extensive migration of Jews from North African and other Arabic speaking communities in which their lives had been threatened, their bodies attacked, and their institutions and possessions defaced. Between 1 October 1955 and 14 April 1956, the UJA supported through its "Special Survivor Fund" the exodus of nearly 26,000 North African Jews (especially from Morocco) as well as their migration to Israel. In the three year period 1955-1957 more than 100,000, and between 1961-1964 more than 125,000 North African/Middle Eastern Jews arrived in Israel. But the exodus drama was not confined to Asia and Africa. ${ }^{1}$

The 1957 campaign sought $\$ 100,000,000$, "over and above" the "regular" campaign, to transfer 80,000 Jews from Egypt and Hungary, primarily, to Israel, while in 1959 it was the exodus of Romanian Jews--allowed only $88 \mathrm{lbs}$. of possessions per person--which propelled the campaign. Although more than 
110,000 Romanian Jews had migrated to Israel from late 1949 through 1952, another exodus began in late 1958 with the Romanians granting 3,000 visas in November and even more in December. And in Poland, where Gomulka's newly formed government suddenly permitted the exodous of Jews, nearly 50,000 exited in 1958-1959 and the vast majority came to Israel. Indeed, nearly twice as many Jewish immigrants arrived in Israel in 1957 as had entered only two years earlier, and between 1961 and 1964, when Algeria especially emptied, more than 220,000 Jewish immigrants settled in Israel. ${ }^{2}$ (See Table $7: 1$ )

Jews came out of diverse lands during this decade, and most migrated with little or nothing. Despite some intergovernmental support, it seemed (or at least the UJA campaigns argued) that without the private initiative of voluntary agencies such as the UJA, Jews in countries of first asylum would die of hunger and of cold. Food, blankets, medicine and the like--at least until the machinery of government relief got in gear--came steadily from the united Jewish Appeal.

The massive rescue efforts of the UJA meant that Israel faced incredibly large absorption tasks in its declared goal of ensuring a home for every new immigrant. The absorption department of the Jewish Agency, charged with the task of providing all immigrants with a roof (or, at least, a canvas tent) over their heads immediately upon arrival, had already begun in 1949 to erect thousands of wooden huts to replace the huge "tent cities" of 1948, and by the end of Israel's first decade 150,000 permanent dwelling units had been erected for immigrants in nearly thirty development towns and villages as well as agricultural settlements. Year by year Israel made progress toward the elimination of the transit camps, especially after its "ship-to-settlement" policy, begun in 1954, took healthy newcomers directly to industrial development areas and rural villages after "selection boards" on the ships made their decisions and radioed truck drivers on shore at Haifa. ${ }^{3}$

Nevertheless, in 1959, 110,000 immigrants still lived in more than fifty shanty slum towns (ma'abarot) of shacks, tin huts, or wooden huts, and feverish (even heroic) efforts to raise money to disband these towns reduced the number to 90,000 in 1960 and 40,000 by 1961 , despite continuous streams of new 
immigrants. But even when these primitive accommodations came down and the immigrants found housing (largely UJA financed) in agricultural settlements, Israel was unable to provide much economic assistance. By 1960, 130,000 immigrant farmers, all arrivals since 1948, lived on 485 settlements, and nearly all of these settlements lacked implements of modern agriculture. UJA funds provided roads and electric power for new settlements, bedding and furnishings for modest flats, textbooks for ulpanim (rapid-language Hebrew schools), as well as maintenance of bedridden newcomers confined to hospitals, expenses for vocational training programs, and the like. ${ }^{4}$

Such maintenance also supported Jews stranded in Morocco or Egypt, Jews remaining in Asia, and eastern or western Europe, and those having fled to South America, Canada, or the United states. This support came from the many millions of dollars spent by the JDC each year in its welfare activities all over the world. (See Table 7:2) But the most common situations presented in UJA publicity during these years were those of immigrant Jews in ma'abarot in Israel. Here are some excerpts from UJA posters, films, and newspaper ads between 1957 and 1961 :

1957: My husband, Ramati, is working today. That is not something we can count on as we wake up in the morning. Ramati is a good, willing worker, but he gets only 15 days work every month on an emergency relief project. When we came from Tripoli a few years ago, I had no idea we would still be in this shack [pictured] after all this time. I try to keep things as clean and nice as I can for the children, but I get so discouraged. What is their future here?

1958: My name is Pinchas. I came from Iraq nine years ago, leaving behind a good business as a rice merchant. My wife, my mother, six children and I have been living in this wood shack [pictured] ever since. My family is barely able to exist on the money I earn distributing milk in the ma'abara. We can't go on like this much longer.

1959: We have been married nine years and living in this shanty all that time [pictured]. We both came from Turkey ten years ago, with my mother-in-law, who lives with us. I work at any kind of job $I$ can get so that we can try to save a little money and get out of the ma'abara.

1960: My eldest son is a brilliant boy who was studying to be a mining engineer when we left poland a little over a year ago. He has received top honors and a scholarship. But when we had the chance to leave, we took it because we wanted our children to grow up as Jews. Unfortunately, my husband, Yakov, 
had to have a stomach operation which disabled him and made him a chronic invalid. Then he had a heart attack and can do no work now. And so my son went to work as a road laborer to support us. He will be going into the army soon. If we could only get out of this shack [pictured], I am sure things would improve for us.

1961: I have worked as night watchman, and it is not easy for me, who was a public relations counsellor and government translator in Egypt. Then I was imprisoned for some months, stripped of everything, and my family expelled. My mother, my wife, and our five children came to Israel. I did not know Hebrew or how to apply my special experience and training here, but we had to live. A decent plce to live would make a great difference in our lives.

Not every Jew living a sub-standard existence in Africa, Asia, or Europe was able to leave his or her land, and the UJA assumed responsibility for temporary and permanent relief of Jews in farflung places. In the fall of 1959, 100,000 Jews dwelt in Mosiem lands on UJA welfare, 10,000 European Jews needed temporary relief, and 55,000 of the latter received permanent relief. 5 A UJA film, "A Mother for Shamsi," filmed in Iran in 1959, highlighted the needs of some of these Jews, as it followed a Joint Distribution Committee public health officer as he provided succor to Jews in the Tehran ghetto. This ghetto, however, was multiplied everywhere; in 1963 the UJA aided 575,000 Jews in twenty-eight lands while in the following year it aided still more--751,000 Jews in thirty-one lands. 6

Herbert A. Friedman, an American born (1918), Yale educated, ordained rabbi (Hebrew Union College, New York, 1944), succeeded Joseph Schwartz as executive vice-chairman in 1955 and remained in this position through 1969. Rabbi Friedman received extensive publicity in the American media and Anglo-Jewish press during his term (1945-47) as Jewish Chaplain of the Berlin Headquarters Command and as assistant advisor on Jewish affairs to the Commanding General of the United states occupation Force in Frankfurt.

Friedman supervised two or three hundred thousand Jews in scores of German and Austrian Displaced Persons camps, and secretly served in the Palestine Haganah directing border crossing rescue operations for Aliyah Bet. Well-known in both JDC and UPA circles, he became a valuable UJA volunteer ("I was their best speaker") during his post-war rabbinate (Denver 1948-5l; Milwaukee 1952-55). Friedman recalls clearly, if 
immodestly, why the UJA leadership chose him after they decided to oust Schwartz: "I was the best candidate they had." 7

The changes and developments which characterized the UJA during these years of rapid movement of hundreds of thousands of Jews, like those of the 1940s, bore the personal touch of the executive vice-chairman, and ranged over the entire UJA operation. The most significant, however, took place in the areas of organizational structure, big gift fundraising, and cash collections.

Rabbi Friedman, three years after taking office, began to plan a manner by which affluent and Jewishly concerned "younger" men, not yet in their forties and with interests somewhat unlike the big givers often twice their age, might be introduced to the world of national and overseas Jewish philanthropy. Friedman experimented, in 1958 and 1959, with "missions," or carefully arranged tours (seminars, visits, meetings) of Israel for young leaders in several different communities. For example, twelve young leaders from Boston inaugurated the local Young Leadership missions in october 1957, with a two week tour; seven "young" Akron, Ohio business executives went on a mission in october 1958 and its impact remains strong more than twenty years later; and in 1959 Friedman organized similar missions in Newark, Kansas City, St. Paul, Atlantic City, and Chicago.

With the conviction that "if you can raise people's insights and knowleage and sense of commitment you'll get more money," all through the campaign year of 1959-60 Friedman sought out potential young leaders:

I began to carry around a little notebook in my pocket for about a year marking down the names of the men whom I saw standing out above the crowd, in all the communities that I visited. I was looking thirty and below. Everytime I would go to a meeting and see a thirty year old guy making a good gift or obviously with some kind of charisma, a potential leader in his own community, I would put his name down in the book.

By the fall of 1960 the UJA prepared to launch its First National Young Leadership Conference, and while 200 men were expected, 350 between the ages of twenty-five and forty and representing thirty-nine states attended a three day conference of speeches, seminars, and workshops on numerous aspects of the UJA. This was only the beginning; early in 1961 the UJA announced the First National Young Leadership overseas study Mission for the spring, and in June more than 100 men spent 
three weeks in Vienna's immigrant reception centers, touring UJA financed projects and communities in Israel, and sharing a meal with Prime Minister Ben Gurion at his s'de Boker home just prior to being solicited. By 1963 the Young Leadership sponsored not only an annual conference and mision, as well as a Jewish "book of the month" selection, but a spring retreat filled with workshops, lectures, and social activities. All three events, and others added steadily (Young Leadership National Cabinet, for example, in 1963) during these years, not only helped to build a sense of solidarity but provided the UJA with the opportunity to introduce a sizeable number of potential big givers to the challenges and opportunities of the United Jewish Appeal. 8

The program, or as Friedman called it, the "movement," produced thousands of alumni and they have "infiltrated the structure of the campaigns up to the very top:"

Take Irwin S. Field, for example. Inside of his own community, first he began as the chairman of the industrial division, then the chairman of the local committee out in the San Fernando valley where he lives and then up in the ranks. Finally, he is the general chairman of the whole city of Los Angeles in the campaign of 1974 and again in 1975. He now gives $\$ 60,000$ and runs a campaign of $\$ 45,000,000$. He is a perfect example of a leader who rose to the top at a young age, with a willing executive director and local establishment behind him, with a national framework, within which he has developed his own reputation. In his own community he reached the top. He did a fantastically good job. He was vice-chairman of the national Young Leadership. This year he was elected as one of the twelve national chairmen of the whole UJA. He is the youngest one. Will he ever get to be the general chairman of the UJA? I hope so.

Friedman spoke these words in 1976; in 1980 and 1981 Irwin $S$. Field served as the national chairman of the UJA, the highest lay position in the appeal.

Friedman's role in this creative endeavor was enormous: he conceived it, crafted it, and nurtured it tenderly, believing that since the UJA "was always an elitist instrument, a leadership instrument, I wanted to educate a certain number of leaders:"

I paid a tremendous amount of personal attention to this program. I took these men on trips to Dachau, to Auschwitz, so they should really understand the Holocaust. I took them many times to Israel. I went to every regional conference myself and I fought with executive directors to accept them in every city. Today it carries the whole weight of the UJA.9 
Another organizational innovation originated by Friedman, himself an ordained rabbi, was a Rabbinical Advisory Council. This council, created in February 1960, with twenty-four reform, conservative, and orthodox rabbis, had as its goal communicating with other rabbis, and congregants, the UJA's goals and programs. BY 1965 the RAC had become active in UJA circles advising on programs, underlining the word "Jewish" in the UJA by strengthening the understanding of Jewish tradition and Jewish values among the staff, sponsoring UJA activities (including missions) within denominations, and, especially, in soliciting other rabbis as well as some congregants. By the end of the 1960s Friedman had even convinced the RAC to push the "100 percent plan"--the concept that a gift to the UJA was a concomitant of synagogue membership. ${ }^{10}$ and in the area of solicitation Friedman expended the most vigorous efforts.

First, he changed the format of the National Inaugural Conferences--which formally launched the UJA campaign each year--to occasions which utilized honoring an individual as a vehicle for large gifts. William Rosenwald (general chairman, 1955-1957) was toasted by Jerry Lewis in 1958 with 1,500 present for the open card-calling; 1,800 saw Jack Benny laud Abba Eban (Israel's Ambassador to the United States) in 1959; and year after year distinguished celebrities, active in Jewish philanthropy, hosted the conference which honored a worthy individual and which raised the largest single sum of any UJA event during the year. (See Table 7:3) Generally speaking, about half the large gifts $(\$ 50,000$ and above) raised in the country each year came from the pledges made during the Inaugural card-calling. Il

secondly, Friedman more fully developed an idea first introduced by Montor and called it a "Good Will Tour." Each year before the fall campaigns got underway--and sometimes in the spring as well--a dozen or so Israelis and a similar number of UJA leaders would divide into two-man teams and visit a large number (seventy-five in two weeks of october 1958) of "key" cities (every campaign visited was called "key") to answer questions, deliver advice, collect any cash proceeds at hand, and provide support and impetus to the local campaign. These were not explicitly fundraising visits--though Friedman urged the teams to "press for cash"--but an opportunity for overseas and national "captains" to motivate the troops. 12 
Third, Friedman organized a vast array of unusually distinguished and articulate (to judge by the letters to the national office) keynote speakers to give the exhortative address in local big gift campaign kick-offs. Herb Friedman himself was a much sought after keynoter; in the 1959 campaign, for example, he gave the kick-off speech in Houston, Los Angeles, Miami, Pittsburgh, portland, San Francisco, Seattle, and Washington, D.C. But his skills included making excellent use of Israeli speakers, and he successfully developed this technique to such an extent that hardly any major campaign city was left without a big drawing card who was also a gifted fundraiser.

In 1957 Friedman hooked Abba Eban into twenty-five cities through a closed circuit network; in 1958 former Prime Minister Moshe Sharett delivered eight keynotes, from Milwaukee to Boston, in ten days; in 1959 Golda Meir, Israel's Foreign Minister, and Abba Eban, visited fourteen cities in ten days; and two years later General Moshe Dayan keynoted Toledo, Kansas City, Columbus, Denver, Toronto, Detroit, San Francisco, New York, and Newark in seventeen days of March. To other campaigns Friedman sent lesser known Israelis--always described as "brilliant" young military leaders, "outstanding" young diplomats, "authoritative" economists, "superb" educators, "vigorous" politicians, and "top experts"--as well as the UJA general chairman, the UJA national chairman, and other proven solicitors. Simultaneously, a distinguished Israeli novelist, singer, journalist, or politician made regular circuits of the UJA campaigns at college and universities, while the UJA used its faculty contacts to secure public lectures and private solicitations for these guests. Like pieces on a giant chessboard, Friedman personally coordinated the movements of his carefully monitored speakers. 13

Fourth, Friedman made maximum use of a variety of missions sent off before and during spring and fall campaigns, missions launched with the goal of eventually regularizing interchange between second echelon American Jewish leadership and second echelon Israeli leadership, i.e., kibbutz, business, and army leaders not invited to America to speak. One type of overseas study Mission, returning just before the annual conference which approved the campaign goal for the following year, consisted of national leaders now armed with facts and figures for their pre-conference lobbying. For example, the Third UJA 
National Overseas Study Mision of eighty national leaders (fall 1956) provided the manpower to establish the $\$ 100,000,000$ Emergecy Rescue Fund; the 1957 mission, according to Rabbi Friedman, "paved the way for adoption of the UJA's 1958 'rescue fund'," for it, like most missions, provided eyewitness reports to the national conference. By 1964 the Tenth Annual UJA National Overseas study Mission (the 1961 mission was cancelled) was so large, and the UJA program to observe so wide-spread, that the 140 leaders divided into five sub-missions (Iran, Italy, France, Austria, Morocco) so that reports could be presented on far-flung JDC rescue and support efforts at the December national conference. And by the fall of 1968, when more than 2,000 executive directors, campaign chairmen, "key" leaders, and solicitors, at their own expense, were ticketed on missions, one planeload left New York every sunday evening.

Beginning with his response to the large-scale immigration of Moroccan Jews to Israel in 1955, Friedman had the ability to dramatize, year after year, some special crisis affecting overseas Jewry, and to make it the focus of a special, Rescue, Survival, Special Emergency, or Emergency Rescue Fund. "The basic principle," Friedman recalled, "was that it was to be all for the UJA and not to be shared with the community." For example, in Columbus, Ohio, 394 individuals made advance gifts in the 1969 campaign. All 394, of course, gave to the regular fund $(\$ 587,808)$--of which the UJA received nearly 55 percent--but 263 took advantage of the "second line" on their pledge card to contribute, in addition to the regular campaign, $\$ 423,186$ to the Israel Emergency Fund--all for Israel. This latter amount, or the "two line" strategy, meant that nearly 75 percent of all the dollars these big givers contributed went to Israel. The result, when multiplied everywhere, was a radical change: the ratio between local and overseas allocations, so unfavorable to the UJA during the early 1950s, now shifted steadily in favor of Israel. 14

A different type of mission, composed of Jewish philanthropists and both Jewish and non-Jewish educators, also went to Israel in 1964, and the result was the realization of yet another long-cherished Friedman dream. The UJA National Leadership Conference on Education, which took place in Israel in late september after $21 / 2$ years of negotiations, launched a five year, $\$ 127,600,000$ Israel Education Fund in America "over 
and above" UJA campaigns, i.e the UJA would not accept a gift from anybody who cut his or her gift to the regular fund. The inaugural goal included funds to build high schools and libraries, to provide thousands of high-school scholarships (secondary education was not compulsory), and much more.

The UJA renewed the program after five years, and it continued to enjoy great success. By 1972 the minimum acceptable gift reached $\$ 100,000$ (to be paid within five years), and the donor could name the facility. The Israel Education Fund had under construction, or already completed (mainly in development towns) ninety-four high schools, eleven public libraries, thirty one centers, ninety three pre-schools, and six sports clubs. Furthermore, it had offered, to immigrant children, more than a thousand scholarships from the nearly $\$ 40,000,000$ raised since the program's inception, and spurred the Israeli government to invest four or five times this amount in support programs. 15

And fifth, Friedman made a powerful imprint upon local campaign leaders with his determination to fight, year after year and in person, for "pcb" or pre-campaign budgeting. Unlike Schwartz and even Montor, he pursued a rigorous schedule of visits to numerous communities, arguing that a larger share of the federation campaign should be committed to the UJA, i.e., overseas. Friedman began these efforts as early as 1949-50 as he volunteered to "solicit" communities--while serving a rabbinate in Denver--and convince them to increase the UJA's share:

I insisted on having meetings in every major community; I was usually the UJA negotiating team, and I fought with the local federation team. Not once, not twice, but year after year. It was a struggle in every town.

I said to a community, last year you raised $\$ 1,000,000$ and you gave us 35 percent. That means you gave us $\$ 350,000$ and you used $\$ 650,000$. What are you going to need next year? You need $\$ 700,000$ ? Fine. We'll make a deal that the first $\$ 700,000$ you keep, but the next $\$ 700,000$ you give to me. So, on $\$ 1,400,000$, instead of $\$ 1,000,000$, we get 50 percent and you get 50 percent. Do you think you can raise $\$ 1,400,000$ instead of $\$ 1,000,000$ ? I will come back and help you. I will solicit people and make speeches. Negotiating, fighting, arguing, and offering a premium. .

By the time he became a UJA professional, Friedman had fought the pre-campaign budgeting wars for years, and little in the 
UJA records or Friedman's recollections suggests that his techniques changed very much in the 1950 s or 1960 s:

I always tried to convince them that the percentage was not important but to raise [the level of the] campaign, for if they raised the [level of the] campaign they can have a little bit more and we will have a lot more money. I fought and fought and fought. " 16

Friedman's fundamental premise, as well as the general communal response, can be succinctly summarized. He regularly argued that the majority of funds in a local community belonged overseas, not only because UJA speakers, promotion, programs, and techniques made large local campaigns possible, but because the specific overseas crises of a given year moved givers the most and loomed far more critical than a hospital or community center. His local "adversaries" responded that American Jews established the UJA as an instrument to assist in raising funds but not to dictate how the funds should be distributed, that a variety of local needs might indeed be felt to be more pressing than the drama of the world-wide exodus to the promised Land, and that local agencies and concerns were subordinated to overseas crises in campaigns only because tons of canned UJA literature simply ignored or even denigrated non-overseas activities.

All of these missions, visions, percentages, and goals would have been, of course, impossible, without cash, and Friedman made vigorous efforts to turn pledges into dollars. Shortly after taking office, he travelled to Morocco and Algeria as well as Israel, and returned to New York with the announcement that the UJA desperately needed $\$ 10,000,000$ cash within sixty days to immediately save 10,000 lives. By 1957 Friedman had, in effect, institutionalized or ritualized this strategy with mid-year UJA national rescue conferences and fall regional cash collection conferences. The June conference witnessed a line-up of communal leaders, whose campaigns had concluded, presenting checks--pledges were unacceptable--in order to turn spring promises into summer dollars for vital UJA programs. The June 1957 cash total, nearly $\$ 45,000,000$, was the highest cash amount for any first six-month campaign period since 1949.17

The fall conferences--regional and national--had the same goal: to turn fall campaign pleages into cash as soon as possible for only dollars, not pledges, were useful in 
absorbing tens of thousands of Jews fleeing their homes. Cash drives, with generous accolades bestowed upon "Honor Roll" and other categories of achievement, punctuated the campaign calendar year after year. The 1961 fall cash arive was so intense that key UJA leaders, who had planned to participate in the Seventh Annual National Overseas Study Mission, were notified that the mission was cancelled and their help eagerly sought in numerous communities for the December cash drive.

Friedman concentrated the UJA's energies largely on the big givers, for he knew well that they determined the success of UJA cash contributions. For example, in the 1969 campaign in Columbus, Ohio, the thirteen gifts over $\$ 10,000--$ which represented only 0.3 percent of the givers-yielded 37 percent of the campaign, while the 208 gifts between $\$ 1,000$ and $\$ 10,000--5.1$ percent of the givers--totalled 36 percent of the campaign. Hence, the UJA had only to apply pressure on 5.4 percent of the Columbus contributors to turn pledges into dollars in order to receive nearly 75 percent of the campaign dollars. 18

The UJA faced not only the problem of obtaining cash, but of responding to those, inside and outside of government, who sought to invoke the law, especially tax legislation, to thwart the transmissal of Jewish philanthropic dollars to other lands. As early as 1957 Senator Allen J. Ellender of Louisiana asked for a study of the tax-exempt contributions to the UJA, for during a tour of Arab lands he heard leaders complain that UJA funds financed Israeli military operations, but UJA leaders felt little threat as the charge was baseless.

The response to sen. Ellender's attacks in 1957 came exclusively from the UJA staff, and these same executives also responded vigorously in 1959-60 to a widely publicized accusation by a member of a prominent Jewish family. James Warburg (1896-1969) had been president of the International Acceptance Bank, director of the Bank of the Manhattan Co., a member of FDR's "brain trust," deputy director of the office of war Information, and a prolific writer on economics, literature, and foreign policy.

In late November of 1959 Warburg addressed a synagogue audience in New Haven, Conn., and announced that he would stop donating to the UJA because it distributed funds not only for relief but to policital parties (especially those he opposed:) in Israel. After a weak and distorted response at the same 
congregation by william Rosenwald, the former general chairman, Warburg renewed his attack in March of 1960 by arguing at Columbia University that the UJA distributed miliions of dollars through political parties and by scoring the UJA for refusing to reveal the (generous) salaries and expense accounts of all executive rank UJA officials.

By early April, UJA professionals and senior Israeli officials began to use the Anglo-Jewish and general press to explain the complex distribution of UJA dollars. None denied Warburg's charges, for they were indeed true, but all patiently explained that the funds in question were used exclusively for "non-political" purposes. Nevertheless, they announced that the UJA would cease distributing funds, even if exclusively philanthropic, via Israeli political parties, and that special boards, packed with Americans, would monitor this decision. Warburg appeared pacified, and the UJA staff felt confident of its decision. ${ }^{19}$

More serious, however, loomed a full-scale $(200$ printed pages) hearing by sen. J. William Fulbright's Committee on Foreign Relations, and an investigation by the Treasury Department of the UJA in 1963 in order to determine whether charitable funds contributed to the UJA were spent for political and other non-charitable purposes. The Internal Revenue service ruled explicitly and unreservedly that UJA contributions were tax deductible, even though the funds were used overseas. Although funds given directly to a foreign organization were ruled non-deductible, when the overseas organization served only as an administrative arm of the domestic organization and the boards of directors of the beneficiaries consisted of Americans who "controlled every facet of [their] operations," the agency's receipts were deductible. 20

Friedman had carefully protected the UJA's tax-exempt status by pushing for the creation in the United states of a new body, the Jewish Agency for Israel, Inc., a few years earlier. This organization supervised disbursement in Israel, through the Jerusalem Jewish Agency (as we have noted often above), of funds raised by the UJA. The Jewish Agency for Israel, Inc., merged with the United Israel Appeal in 1966 and changed its name to the United Israel Appeal, Inc. Its board of directors consisted of 100 members drawn from the CJFWF, 100 from American zionist organizations, and ten "at large" 
persons. There was, therefore, no violation of the "Foreign Agents Registration Act." 21

As the first decade of Herbert Friedman's stewardship of the UJA came to a close, American Jewish philanthropy on behalf of world Jewry was carefully organized, vigorously pursued, and unrelentlessly defended. No one was able to imagine, or at least to articulate a vision, of how much potential cash remained untapped. A brief but explosive war in Israel (1967) was quickly to demonstrate not only the potential and the ability to harness it, but the skills necessary to sustain giving, well after the war ended, on a plateau never before approached. Rabbi Friedman could never have imagined that less than twenty years after he startled his leadership with a $\$ 25,000,000$ emergency fund, the UJA would propose an emergency fund ten times as large, or that twenty years later more than twenty Jews would give more than $\$ 500,000$ to the UJA. Friedman, however, put it well: "The UJA taught the Jews of America how to give money." 22 
CHAPTER 8

THE AMERICAN JEWISH PHILANTHROPIC RESPONSE TO THE SIX DAY AND YOM KIPPUR WARS

A. Columbus, Ohio--May/June 1967: A Case Study

In the ' 67 War the UJA didn't raise money, it took it in.

Herbert Friedman, July 1981

When Israel's very survival in 1967 depended upon victory in the Six Day War, and subsequently in the Yom Kippur War, organized Jewish philanthropy in American communities reached new heights. During little more than two weeks which marked the height of the 1967 crisis (22 May--10 June), American Jews gave over $\$ 100,000,000$, the bulk in cash, to the Israel Emergency Fund of the United Jewish Appeal. In Columbus, Ohio, the $\$ 1,000,000+$ campaigns of 1968 through 1973, and especially the incredible $\$ 3,600,000$ campaign following the 1973 War--from a Jewry numbering less than 15,000--resulted from investing enormous amounts of community organizational skill into the tempest-like days of June 1967 and October 1973.

With the outbreak of the Six Day war, American Jews assumed financial responsibility for vast and unprecedented health, education, welfare, relief, and resettlement needs of immigrants and residents in Israel which the Israeli economy could not absorb. ${ }^{1}$ At 4:00 p.m. on 5 June 1967, the United Jewish Fund representatives had just returned to Columbus from a national UJA-CJFWF emergency meeting; they were already explaining to the executive committee:

Israel is totally mobilized for defense as the Arabs have threatened open conflict. As a result of total mobilization of manpower, resources and finances for its security, the health and welfare needs of refugees and much of the civilian population required financial assistance from sources other than the government. A major source of Jewish Agency funds, the government, has been eliminated. The UJA requires immediately Inillions of dollars. 2

This so deeply stirred the executive committee that they voted unanimously to begin an Israel Emergency Fund campaign and to sponsor emergency communal meetings. The UJF board of trustees, which met at $8: 00 \mathrm{p} . \mathrm{m}$. that same night, heard a report on the progress of the war which had begun that morning; 
the board approved the executive committee's recommendation. ${ }^{3}$ Once an energency fund was launched, the reaction of Columbus Jewry was far more intense and widespread than anyone could have predicted. Indeed, all over America Israel's crisis dominated Jewish thoughts and emotions to the exclusion of all else; Jews sat glued to their TV sets, watching the U.N. debates and Abba Eban's performance. This held true not only for affiliated Jews, but for many seemingly untouched by such commitments, who had never participated in organizational Jewish life. And at least one perceptive commentator of modern Jewish life found this response almost impossible to explain:

There are no conventional Western theological terms with which to explain this, and most contemporary Jews experience these emotions without knowing how to

American Jews, committed and indifferent, have usually responded to external danger by giving money--but on this occasion the fountains overflowed. Men, women, and children began contributing to the emergency fund and Israel Bonds in amounts no one imagined possible. The Israel Emergency Fund, a cooperative effort of the United Jewish Appeal and the Council of Jewish Federations and Welfare Funds, replaced the "grass roots" emergency committee, which had already sponsored a "special crisis meeting" in Columbus on 28 May where $\$ 300,000$ was either paid on pledges made to the regular campaign or promised should an emergency fund campaign be launched. 5

The two to three hundred persons who gathered on that rainy Sunday evening at the end of May needed little incentive, and clearly did not have to await the start of the war or orders from New York. On 16 May Egypt demanded the withdrawal of all United Nations troops from two strategic points, one of which was Sharm-el-Sheikh, the fortress controlling the entrance into the Gulf of Aqaba, and on 22 May announced the closure of the Straits of Tiran to Israel and the blockade of the port of Eilat. On 26 May, federation leadership sent 262 telegrams to the homes of selected Columbus Jews urging attendance at Tifereth Israel on 28 May. The UJF prepared and completed this activity even before the board of the UJA met in special session in New York on Monday, 29 May, and well before the UJA "lit up every community in the country" (Herbert Friedman's phrase) with its national conference on sunday, 4 June.

A week later the Israel Emergency Fund came into existence in Columbus, and two major events dominated the frenzied week. 
First, the emergency fund sponsored a "large gifts" meeting on 8 June at the Winding Hollow Country Club for 400 persons who were exhilarated by the Israelis' overwhelming victory. Hence, by the time the first public fundraising meetings could be convened, victory was a foregone conclusion, and the "pep talk" at the meeting emphasized not cash for victory but "cash for peace," i.e. to pay for the war. Later that week, on Saturday night, a communal rally at Temple Israel drew 500 persons. With the Six Day War over, the emergency fund had raised as much by June as had been raised in the entire 1967 regular campaign which concluded two months earlier. By 29 June more than $\$ 611,000$ had been collected, and by 11 August the fund had received $\$ 727,000$ in cash. 6

In almost every Jewish community, the brief emergency campaign (less than one week) surpassed the regular campaigns although, as in Columbus, 1967 regular campaign totals had achieved their highest levels in twenty years. Men and women across the country, Jewish and non-Jewish, 7 pledged unprecendented amounts to the IEF (See Table 8:1); many of these were the same Jews who had recently given substantial contributions to their regular campaign and redeemed those pledges far in advance of planned payments. This took place with a speed and magnitude unparalleled in American Jewish history, and the IEF's $\$ 173,000,000$ total surpassed the regular campaign total of $\$ 145,000,000$ by almost 20 percent. While not able to raise $\$ 1,000,000$ per minute as one New York City luncheon reportedly accomplished in fifteen minutes of giving, nor secure any of the $\$ 1,000,000$ gifts announced nationally, by the end of July, Columbus had impressive emergency fund statistics; its Jews contributed more money than the larger cities of New Haven, Kansas City, Houston, and Buffalo. 8

Varied activities highlighted the frantic week following 5 June in Columbus. Full-page ads in the two Columbus dailies solicited support for the Israel Emergency Fund; a briefing was held at the Columbus Country Club for top non-Jewish business officials; a TWX machine tied the UJF into the national UJA network of teletype and telegraph machines extending from coast to coast, bringing messages of support from communities around the country. Hundreds of volunteers sent out mailings, bills, and letters; made calls ("Hello: I'm calling from the UJF headquarters and the following is the latest report we got from Tel Aviv; I want from you $\$ 1,000$, yes or no, fast, as I have a 
lot of people to call."); sorted envelopes; typed lists; and made contributions of time wherever possible. "The UJA did not conduct a campaign," one leader noted; "the Jews simply gave and the federation took. ${ }^{9}$

The whirlwind month of June concluded with a statewide Israel Bonds dinner ( $\$ 500$ minimum) on 25 June at the executive mansion hosted by the Governor. The bond organization had postponed the start of its summer and fall campaign in deference to the priorities of war; yet members appeared undismayed by the challenge of raising $\$ 500$ apiece from "pledged out" Columbus Jews. 10

One final indication of the impact of the Six Day War and the Israel Emergency Fund upon Columbus Jewry is shown by comparing the gifts of individual contributors to the UJF and IEF campaigns, before and after 1967. As demonstrated by Table $8: 2$, a listing of the gifts of two representative Jewish leaders, while the events of those six days had some impact upon regular campaign contributions in subsequent years, they strikingly influenced emergency fund donations.

Hundreds, even a thousand, Columbus Jews suddenly found funds previously untapped to contribute to Israel's survival and well-being. From this time forth Israel acted as a focus of worldwide Jewish emotional loyalty and as a preserver of a sense of Jewish identity for Columbus Jews.

Utilizing Israel's potential to the utmost, the UJA kept interest in Israel alive by continually dispensing information, through the local federation, all year long, even though the campaign formally lasted for less than a season. Israel programming became the top priority post-1967, and this was reflected in budgets, staffs, projects, and concerns. By the beginning of the Yom Kippur War, Israel was the number-one item on the UJF agenda, and hundreds of Jews were coming forward in one way or another to do something for Israel through the organized channels of American Jewish philanthropy. Israel permeated UJF programs and publicity; Israeli generals were brought to appeal for more overseas support at boards of trustees meetings; continual full-page ads ran in the local Ohio Jewish Chronicle; and rewards for the leadership, and the large contributors, included lunch in Jerusalem with the Prime Minister, a tour of a battlefield with a general, or dinner with an Israeli ambassador. All of this had been done so souccessfully that support for Israel almost became a sine gua 
non for leadership in the community--nonsupport was sometimes cause for communal censure. The result: the mobilization of American Jewry for the crisis of October 1973 flowed directly from the organizational achievements of the UJA and its local representatives. ${ }^{11}$

B. Boston, Massachusetts--October, 1973: A Case study

"me Elizabeth Uretsky send you this money [twenty pennies] so that you will win the ware."

The response of American Jewry to the Yom Kippur war--especially the outpouring of dollars--reminds one of the first days of June during the Six Day War, but there occured a somberness and heaviness as the battlenews unfolded, as well as a level of giving far ahead of the record sums collected six years earlier. The deadly fighting on several fronts, massive pouring-in of soviet weaponry, and abundant casualties all seemed to indicate an enormous Israeli defeat. This, however, only induced the UJA and local federations, which by nightfall on the outbreak of the war, saturday, 6 october, had already initiated cash drives, to intensify their efforts to have American Jews redeem their 1973 pledges and give early to the 1974 campaign. The first move was a combined UJA-CJFWF commitment made within the first twenty-four hours of the war (on sunday, 7 october) to raise $\$ 100,000,000$ in cash immediately (between Monday and Friday, 8-12 october); by the end of the first week, $\$ 107,000,000$ had actually been raised and one week later Jewish philanthropic leaders would call upon American Jewry to raise $\$ 750,000,000$ for 1974.12

The Boston Jewish community did not await the UJA summons, which came in the form of a national telephone hook-up with UJA-CJFWF "leaders" (large givers) as well as the Israeli Finance Minister, Pinhas Sapir. A Lexington synagogue rally following Saturday's Yom Kippur worship services raised $\$ 14,000$ for the IEF, and at daybreak on sunday virtual 'round-the-clock activity began at the Combined Jewish Philanthropies' office with the executive director later describing this response as "apparently one of the earliest and most effective of any community in the country." Film footage recorded the rush of volunteers who, without having been called, stood at the cJP headquarters that morning and then poured into the office asking "What can we do?" When the phone bank was installed 
later that afternoon, the phone company technician emptied his wallet before leaving. 13

On Monday, the CJP, the principal Boston fundraising arm for overseas Jewry, announced a 48 hour goal of $\$ 3,000,000$; a flurry of activity began all over the Boston area; and by Tuesday morning the CJP totalled $\$ 1,800,000$ in gifts and pledges. In Pittsfield, a Tuesday noon rally drew 350 and raised $\$ 100,000$; that evening, when comnunities everywhere held open rallies to raise funds from general contributors, a synagogue rally in Medford raised $\$ 100,000$ while a Chelsea synagogue rally saw 300 "men, women, teens, and children lined up to make their contributions;" Medford and Chelsea were but two of forty sites of synagogue rallies that evening. And not only during the early days of the war, when Boston Jewry feared the worst, but for two and three weeks after the war the CJP sustained high levels of giving to the Israel Emergency Fund with congregational rallies, mass meetings, and walk- or sell-a-thons, i.e., merchants donating one day's profits to the CJP or IER. 14

While the regular cJp staff went on an emergency work schedule, volunteers, in seemingly endless numbers, filled the headquarters to help make phone calls, register pledges, open envelopes with donations, accept parcels of medications and blankets, answer questions, provide "authoritative information," and assist the "Crisis Committee" in coordinating public and communal relations. McDonald's donated $100 \mathrm{fish}$ sandwiches gratis each day; 500 college-age students volunteered to go to Israel to help; all 300 phones at the headquarters were staffed from 9:00 a.m. to 10:00 p.m. the entire week. Mindy Douglas, for example, a fifteen year old Brookline high school student, volunteered all day Sunday, 7 october, every afternoon and evening 8-12 october, and three more weekends. She "spent many sleeples nights at the CJP fourth floor conference room collating, supervising, telephoning, receiving calls, running errands, delivering meeting invitations to big givers, and preparing $1,600 \mathrm{kits}$ for the 14 October student Mobilization for Israel drive." Mindy, like so many other volunteers, played an important role in the campaign success. ${ }^{15}$

The responses to the CJP appeals, and the unsolicited donations too, came from the young and the old, the committed and uncommitted, and even non-Jews, as the Boston fundraisers 
seemed able to reach middle-level and small-givers as well as the very big donors. The Maimonides School "Learnathon" raised $\$ 1,200$ the first week; Martha Livingston charged five friends $\$ 3.00$ each to see home movies of her Israel trip and sent the $\$ 15.00$ to the CJP; the Beth El Federation of Temple Youth raised $\$ 255$ for the IEF from a pumpkin sale; Lauri scher sold $\$ 10.25$ worth of terrariums and sent the money to the CJP; and one Jewish woman wrote a note with her check stating: "although I arn unemployed and my husband is a grad student we are sending you about $2 / 3$ of this week's unemployment check because Israel must survive."

Kenny and David Frieze, ages four and six, sent pennies in the mail, while Fred Yankelewitz attached a note to his $\$ 40$ check saying: "I am going on eighty-five; feeble-income scarce-savings gone; want to help." And Estelle Leontief sent $\$ 100$ "and prayers--whatever affect the prayers of a Jewish atheist can have." Herbert Bicherstoff contributed generously and noted that he "worked all [my] life with Jewish people and prayed for Israel's lasting peace;" Harry Thompson and friends donated $25 \not$ from every poker ante one Tuesday night; numerous non-Jewish selectmen, mayors, bankers, and physicians sent donations, and one eighty-four year old catholic widow, hospitalized permanently, sent half her social security check. CJP advertising, and general news coverage, kept not only Israel's financial plight but the CJP address in the public consciousnees. 16

Tables $7: 3,8: 1,8: 2$, and $9: 5$ reveal the extent to which new levels of giving were established by American Jewry as a whole, specific Jewish communities, as well as by individual American Jews as a result of the wars of 1967 and 1973. The sense of what big giving might mean or could actually mean, greatly expanded, and all subsequent campaigns benefitted. Herbert Friedman noted that

The long-range implication of the 167 spurt was the fact that it raised the base level of the community [so] that you could then have a 173 or a 174 campaign the size you did. . . it enabled the 174 campaign to be up in the $\$ 700,000,000$ range because it took the base off of the $\$ 125,000,000$ plateau and kicked it up into the $\$ 250,000,000$ and $\$ 300,000,000$ range and only from that new plateau could you jump to the $\$ 700,000,000$ in the Yom Kippur War. 
The ability of the organized philanthropic community to quickly mobilize volunteer solicitors, and for othem to quickly extract and relay to Israel millions of Jewish dollars, had reached levels of abundant sophistication. But one small sign of this skill was the incorporation of a 1973 emergency fund into the 1974 regular campaign, i.e., the explicit statement that UJA fundraising was a year-round activity. The organized philanthropy network not only cashed in quickly during the critical days of June 1967 and october 1973, but carefully sustained extraordinary, high levels for weeks after each crisis. Leonard Fein is accurate when he describes the spontaneity and aggressiveness of American Jewry in 1967:

- . we lost our cool completely. By June 5 [1967] we had tossed aside the manuals and were behaving in unprecedentedly disruptive ways. We begged, we pleaded, we demanded, we insulted, we threatened, we promised, we were aggressive, petulant, temperamental. We threw a tantrum. 17 


\section{CHAPTER 9}

THE "MANAGEMENT TEAM": THE INCREASED ROLE OF LAY LEADERS AND PROFESSIONAL STAFF IN THE 1970s

As the decade of the 1970s got underway, the United Jewish Appeal's major constituents, and their needs, had not changed much. The United Israel Appeal continued to be the primary beneficiary of funds raised by the UJA through its Regular and Israel Emergency fund campaigns. The UIA's agent in Israel remained the Jewish Agency, and the UIA determined the appropriate use of UJA funds for the support of the Agency's work with immigrants, their immigration into Israel's life (health, housing, education, job training), and miscellaneous programs such as agricultural settlements and youth services. In effect, then, the UIA functioned autonomousiy, and it contracted with the Jewish Agency for work done on its behalf in Israel. With the sudden spurt of soviet Jewish immigration to Israel, beginning in 1971/72, these tasks once again assumed earlier proportions. ${ }^{1}$

The American Jewish Joint Distribution Committee, including ORT and Malben, still maintained a wide range of health, welfare, rehabilitation, education, and cultural services for needy Jews in at least thirty countries around the world, includng Israel. A glance at JDC activities at the beginning of the decade will highlight the extensive sweep of its programs: the Joint spent $\$ 23,100,000$ on more than 300,000 Jews in twenty-five countries in 1970; $\$ 23,300,000$ on 233,000 Jews in twenty-five lands in 1971; $\$ 27,000,000$ on 300,000 Jews one year later; and over $\$ 40,000,000$ on 500,000 men, women and children in $1981 .^{2}$

550,000 of the 750,000 Jews in western Europe resided in France, and 75 percent of JDC European allocations in 1971 aided North African Jews (mostly Algerian, but also Moroccan and Tunisian) in that country. The aid included socio-medical services, support of ORT vocational training centers, Jewish day schools, and "third age" (senior citizen) centers in forty French cities.

50,000 Jews remained in Morocco, Algeria, and Tunisia $(35,000$ dwelt in Morocco), and about $2 / 5$ benefitted from JDC-supported programs $(15,500$ in Morocco). Most of those receiving aid consisted of children attending JDC assisted schools and isolated, dependent, non-emigrable aged. 
of Iran's 75,000 Jews, about 20,000 depended upon JDC educational, medical, and social welfare services, while large numbers of the 750,000 South American Jews--especially the 500,000 in Argentina and the 35,000 in Chile--needed JDC help as more and more affluent members of the community emigrated.

In eastern Europe, the JDC received permission to operateprograms only in Romania and Yugoslavia, and of the 100,000 Romanian Jews, a sizeable number were aged, sick, destitute, and requiring urgent help. The Joint also aided 80,000 or so other East European Jews in 1971, at a cost of $\$ 2,600,000$, through relief-in-transit (informal, temporary) programs.

In 1971, the JDC allocated about a third $(\$ 8,200,000)$ of its resources to aid 30,000 persons--especially the aged, chronically ill, handicapped, and mentally impaired newcomers--in Malben programs in Israel. Malben, by 1971, included six homes accommodating close to 2,200 residents, a 100-bed hospital for the chronically ill as well as for rehabilitation, and professional help for immigrant children who were victims of cerebral palsy, deafness, blindness, neuromuscular disorders and mental retardation.

And finally, the United Hias Service, aiding Jewish immigrants settling in countries other than Israel, and the New York Association for New Americans (NYANA), aiding Jewish immigrants settling in the Greater New York area, completed the UJA constituents. All of these organizations received their funds from a percentage of the campaign totals achieved in about 223 federations and welfare funds and nearly 900 independent and combined campaigns.

The United Jewish Appeal of the 1970 s cannot be understood or explained, in contrast to three previous decades, through the strengths and weaknesses of the executive vice-chairman, Irving Bernstein (b. 1921). This is not in any way a negative statement about Mr. Bernstein, a man who demonstrated outstanding organizational and solicitation talents during his years as director of the west coast region (1950-1961) and assistant executive vice-chairman (1962-1968) before assuming the position of executive vice-chairman in 1969.

Mr. Bernstein, in interviews, speeches, and letters, took care to speak of the "management team," and by that he meant his full-time, profssional associates--men with advance degrees in the humanities, behavioral sciences, social sciences, and law--the large UJA secretarial and clerical "team," and the 
"top" lay leaders, all of whom he utilized in unprecedented ways. 3

The key professional associates on Mr. Bernstein's management team consisted of an associate executive vice-chairman (who headed the major gifts $(\$ 10,000+$ ) task force), an assistant executive vice-chairman (directing the national campaign staff), an assistant executive vice-chairman (heading administration), the executive director (taking responsibility for labor relations and internal systems), and the director of public relations. Mr. Bernstein took pride in his year 'round consultations on all phases of campaign planning and execution with this group of UJA staff.

Voluntary national leadership had always been an important resource of the UJA, but previous chief professional officers primarily utilized the general chairman and a small body of national chairmen for consultation purposes. Even the large executive committee, often 100 strong, and the national campaign cabinet, usually twice the size, only met once or twice a year and served primarily as advisors (executive committee) or as honorary leaders (national campaign cabinet). They were really not operating entities but rather were composed of members chosen for the size of their gifts. Herb Friedman described it this way:

There were no discussions or meetings held with the
cabinet or the executive committee or any official
body of the UJA defining the major historic problem or
what our thrust will be. Everything was at my
initiative and I used to come to them [lay leaders]
and say: "I think we should do this and that." As the
UJA grew. . we would have an executive commitee
that met once in a while, a few times a year. I would
go to the executive committee and say: "here is what
is happenig; here is the line of speeches that I am
making." I would suggest the line. There would be
some discussion, but never very serious. They
accepted it.

It was a semi-dictatorship--two, three, or four people always making the inside decisions: me, the current campaign chairman, the [prospective] chairman, and maybe one or two more people and that's it. ${ }^{4}$

Mr. Bernstein, however, began to revitalize the role of national lay leaders as soon as he became executive vice-chairman. He assigned increased responsibility especially to the national women's division, young leadership cabinet, rabbinic cabinet (formerly the RAC), national campaign cabinet, and executive comittee, while establishing several new 
departments, including the department of special appeals, the faculty advisory cabinet, the young women's leadership council, and the university programs department.

Foremost among those with increased responsibility were the members of the executive committee, for they had the obligation to review all aspects of the campaign, and to establish "campaign cabinets" charged with leading the actual campaign. This national campaign cabinet, of 200 or so men chosen and organized (after 1974) on a regional basis, constructed, led, and stimulated the entire process. By studying the role of these men simultaneously in the midst of one campaign (1972) and in preparation for another (1973) we can begin to understand the greatly expanded role which lay leaders played in UJA policy.

To begin, let us consider the men who composed the forty-two member executive committee (thirty-eight attended the fifth consecutive executive committee retreat at williamsburg in June 1972), for we obtained biographical sketches from thirty-four. (See Table 9:1) First, they were wealthy men, who usually owned, chaired, or directed companies of their own. Second, they were men who gave generously to the UJA through, of course, their local federation or welfare funds, and to other charitable causes as well, especially schools and hospitals. But this was not all, or even sufficient, for in nearly every case the members of the executive committee moved into leadership positions "vertically"--by hard work in local and/or national campaigns for Jewish philanthropy--rather than merely by large gifts to the campaign. The latter were necessary, but they did not serve as a substitute for extensive experience in the raising and allocating of dollars.

This group of skilled laymen intimately involved themselves, together with national and communal professionals, in the creation and implementation of much of the UJA program. Five significant areas of their activity in 1972 included Project Potential, Operation Upgrade, Missions (Operation Israel), Operation Breakthrough, and the 1972 campaign itself.

Project Potential emerged from an executive committee recommendation late in 1971, and meetings of professional staff members in May 1972. The executive committee had suggested that the staff prepare detailed profiles of individual "problem communities"--especially their professional fundraisers and lay leaders--and that these be shared and discussed. The staff 
considered practical approaches to communities of varying sizes, and narrowed twenty-nine possible candidates down to one large (Cincinnati), one medium (New orleans), and one small (Teaneck, New Jersey) campaign, and prepared in-depth profiles, from field investigations--which were mailed to executive committee members several weeks before the retreat:

Exhibit \#1

New Orelans: Mr.

Company: Acli International, green coffee importers with extensive holdings in Brazil and Columbia

Boards: Times-Picayune Publishers; Tulane U.; Hibernia Bank

Philanthropy: Large gifts to Tulane...

Gives for social acceptance, e.g. if D.F. of Coca-Cola or D.F. of Merrill, Lynch requests a gift he is only too happy to give...

Attended a meeting, at invitation of another Jewish coffee importer, to hear a visiting soviet Jew, but refused to discuss a gift to the JWF...

Non-giver to the JWF, IEF, UJA...

Threw our campaign chairman out of his office three years ago...

Exhibit \#2

Seattle: Campaign Problems

A strange combination of very dedicated leaders, and nonleadership...

No stable professional leadership [and] no continuing stable community lay leadership...

The traditional wealthy in town are not responsive to solicitation, or will make no appointments...

The executive director: little campaign strength, no respect from the community, no self-organization...

An excellent community for Project Potential program...

Exhibit \#3

New Orleans: Campaign Problems

1972 Nationally: $1 / 2$ of 1 percent of the contributors gave 50 percent of the entire campaign

New Orelans: $1 / 2$ of 1 percent of the contributors gave 16 percent of the entire campaign

Nationally: 5 percent of the contributors gave 85 percent of the entire campaign

New Orleans: $71 / 2$ percent of the contributors gave 75 percent of the entire campaign

The executive committee, having studied scores of analyses such as these, presented a general nine-point guide for campaigns in problem cities, and made an effort to respond to each of the specific problems. In the case of New orleans, for example, the executive committee suggested that the UJA send Mr. R.C., of the Continental Coffee Company in Chicago, to New orleans to solicit the coffee importer there for $\$ 50,000$ but "be willing to accept $\$ 25,000, "$ and that parlor meetings of big 
givers be arranged not by having all the men of the same dollar category or industry together but by making all the guests friends of the host irrespective of their level of giving or trade division. Many of their suggestions said, in effect, that greater cooperation and communication between the national UJA and the local federations would enable "potential to become actual," and several New York leaders spoke of their own version of Project Potential--operation Bootstrap--dedicated to doubling in 1972 the number of contributors $(3,500)$ who gave $\$ 2,500$ or more to the UJA of Greater New York in $1971 .^{5}$

The suggestion made by the executive committee for soliciting the potential donor in New orleans signalled a technique called operation Upgrade. First used in the fall campaigns in 1971, its goal was to bring especialy effective nembers of the executive committee, or other national officers (national chairmen or members of the national campaign cabinet) into a city for a day or two of intensive solicitations of the biggest givers in the presence of local laymen who had made appointments with prospects in the (mostly) $\$ 1,000-\$ 10,000$ range and who requested such help frm the UJA. From an initial pool of thirty-five solicitors in october 1971, the number of volunteers reached 150 by June 1972. These were dedicated men comitted to an average of one solicitation day per month, at their own expense, in another city.

At the executive committee retreat, the UJA staff could point to incredible successes after only little more than half a year of the first Operation Upgrade campaign. (See Table 9:2) Not only had nearly $\$ 800,000$ in new money, from 840 donors, been raised in 1972, but this sum represented contributions of 47 percent more than these 840 donors had given in 1971. In addition, solicitors in the operation upgrade program closed 612 of the 840 gifts $(73$ percent) on the day of solicitation. And finally, in a special phase of operation Upgrade $(\$ 10,000+)$ in which thirty-two or forty solicitations were closed, the 1972 value of the gifts $(\$ 797,619)$ was $\$ 155,119$ (24 percent) more than the 1971 value. The "Operation" demonstrated most clearly how the national resources of the UJA could be made available to local campaigns. ${ }^{6}$

At the request of the executive committee in 1971, the UJA restructured its missions for late 1972 (the kick-off for the 1973 campaign) in several ways (Operation Israel). First, the pre-mission programming in communities was intensified; second, 
the UJA field staff vigorously recruited for the missions ("M.S.'s gift in 1974 was $\$ 25,000$; I rate him at $\$ 75,000$, please reserve a place for him at the UJA Metals Industry study Mission."); third, the number of missions was greatly increased, so that already by June over 2,600 young leaders, big givers, campaign leaders, campus organizers, and national officers had been on "fact-finding missions" to Europe and/or Israel. Fourth, in response to specific executive committee recommendations, the UJA inaugurated "cameo" missions: three days of arduous itineraries for top leaders of selected communities which concluded with intensive solicitation in order to attain in the words of one member of the executive committee, "bellwether gifts, solicited early for their inspirational effect on the campaign." Meetings with a Minister, a General, and Jewish Agency officials, as well as visits to an Absorption Center to meet newly arrived immgrants and to other social service agencies, were followed by intensive solicitation. (See Table 9:3)

Despite these changes in the missions, the program and goals for the participants remained much the same in the $1970 \mathrm{~s}$ as during the previous decade. Those who went on the mission saw for themselves Israel's accomplishments, heard the many unforgettable stories that individual Israelis had to tell, and came to know the workings of the UJA in action, not just in the abstract, by visits to absorption centers, hospitals, and social welfare agencies. Moreover, missions included briefings by top government leaders, usually highlighting the human consequences for Israel of the military-political crises in the Middle East and always explaining that American Jews must underwrite, carry, sustain, support, or bankroll the high cost of Israel's survival.

Finally, the executive committee constantly reviewed and evaluated the Prime Minister's Mission and the overseas study Conference [Mission] where the largest sums were pledged. Several suggestions made at the retreat were implemented for the Prime Minister's Mission of late August, and the Overseas Study Conferences of October 1972; the former resulted in 132 men giving $\$ 14,355,000$ (vs. $\$ 11,640,000$ in $1972--a 23$ percent increase) and the latter in 192 gifts yielding $\$ 12,025,000$ (vs. $\$ 8,750,000$ in $1971--a 37.4$ percent increase). ${ }^{7}$

operation Breakthrough, a new program in 1971/72, was the joint brainchild of the executive committee and the UJA staff. 
It sought to maximize effective solicitation preparation, solicitation follow-up, and even solicitation itself. The research phase consisted of an effort to obtain updated financial information on prospective big givers, not merely from published sources (Dun \& Bradstreet Reports, Dun \& Bradstreet Million Dollar Directory etc.) but from informal contacts. Operation Breakthrough even initiated an effort to find women of independent means-to identify companies, for example, that late husbands of widows were associated with, and then to confirm their financial holdings much like a Dun \& Bradstreet reporter might do.

The solicitation follow-up emerged from executive committee comments that big givers, say $\$ 50,000+$, were often ignored between annual solicitations. Indeed, even those who made gifts of over $\$ 1,000,000-$ and seven men did so at the UJA of Greater New York Pacesetter dinner on 10 February--were often given minimal attention. The executive committee recommended that operation Breakthrough send Judaica books to a donor on his birthday, host an occasional private dinner without solicitation, invite the contributor to meet an Israeli consul General or a visiting Ambassador. Intensive follow-ups were initiated in 1972 and reviewed by the executive committee. ${ }^{8}$

Finally, operation Breakthrough arranged solicitation seminars for campaign leaders all over the united states. These emphasized the psychology of solicitation, and some of the most gifted solicitors shared their expertise with those less skilled in such areas as face-to-face solicitation, card-calling, two-on-one solicitation, and big gift parlor meetings ("small meetings mean big money and big meetings mean small money"). Additionally, the UJA's single most gifted Israeli solicitor intensively trained four or five carefully selected Israelis who came to the United States and observed skilled communal solicitors, then solicited in the presence of these experts, and finally were sent alone on operation Breakthrough. They became known as "resident solicitors," for they were assigned to a specific city for a period of two or three weeks for the sole purpose of soliciting the major contributors. ${ }^{9}$

of course, not all resident solicitors were equally attractive: the president of the Jewish Welfare Federation of Chicago and UJA executive committee member, Raymond Epstein, wrote a 4 p. letter to Irving Bernstein and accused Aryeh 
Nesher, a long-time Israeli solicitor with remarkable successes, of being not only "unproductive" and "disruptive" but "dangerous to our community," because he "solicited under UJA auspices without the advance approval of the JWF of Chicago." Such problems in communication inevitably arose, but one is far more impressed with the ability of the UJA to coordinate its solicitor with local needs. More importantly, this notion of resident solicitors represented just one of eight areas of new proposals members of the executive committee made to the UJA staff at the retreat. 10

Although the executive committee played an important role in initiating, carrying out, and evaluating new programs as well as in revitalizing old ones, it was in the campaign arena itself that members of the executive committee most involved themselves. We have already noted that they were the backbone of Project Potential and operation Upgrade, and key ingredients in operation Breakthrough, but their role extended even beyond these areas. Two of the most important were over-all campaign scheduling and cash collection.

The executive committee continuously evaluated the annual campaign schedule, rearranging this or that event to maximize its importance in the over-all program. It was only after one full day of discussion and evaluation of timing and content at the retreat that the following activities of the 1973 "Keep the Promise" campaign unfolded in the final order in which they appear below: ${ }^{11}$

Prime Minister's Mission, 28 August-1 September, which this year will give even greater consideration to the gift potential of participants. Invitations will come from the Prime Minster and the VIP itinerary will be concluded with solicitation.

Presentation of a proposed 1973 campaign goal at the Council of Jewish Federations and Welfare Funds' board of governors meeting 14-17 september, followed by quota-setting meetings in each community with the participation of overseas and national leadership.

Operation Freedom to be resumed at the end of September, and a number of Soviet Jewish immigrants to be brought to this country to help in the campaign.

The President of Israel will officially open Israel's 25 th anniversary year this fall, and lit menorahs will be flown to the United States for appropriate ceremonies in campaigns.

In October, four or five Israelis, trained as solicitors this summer, will start to come to the 
United states--one each month--in order to make gift solicitations in communities.

The study Conference in Israel, for $\$ 20,000$ minimum gifts--2-9 october--to be closely associated with Israel's 25 th year and to provide the usual factual preparation and tone-setting for the campaign leadership.

The on-going operation Israel series $(\$ 750$ minimum gift), division missions (women's, young leadership, student), and cameo missions to start 15 october and continue through January. The latter, of three or four days duration, will resemble the Prime Minister's Mission but will not include her.

Concerted effort to get a maximum number of community campaign chairmen to Israel, where they will receive a 25 th anniversary award made to their communities for service to Israel, and be photographed with a prominent Israeli who will present the award.

Operation Breakthrough to solicit nongivers (especially "paper millionaires") by two man soljcitation teams.

A national meeting for potential million dollar gift contributors in New York on 15 November with the participation of Israel's Defense Minister Moshe Dayan (this meeting would yield twelve pledges totalling $\$ 14,000,000$, including two gifts of $\$ 2,000,000$ each for the first time in UJA history).

Soljcitiations by Yosef Tekoah, Israel's Ambassador to the United Nations, of significant potential contributors at the United Nations, and direct solicitation, by the UJA Israel office, of visitors and missjons.

Operation Upgrade to include the solicitation of donors in the $\$ 1,000$ to $\$ 10,000$ category, by one of more than 150 outside solicitors.

Newspapermen's missions to include "key" reporters from cities raising at least $\$ 1,000,000$ in order to encourage articles on Israel.

The UJA $\$ 50,000$ minimum Inaugural luncheon at an "elegant" New York City restaurant with a high-level Israeli personality on 7 December, to launch the national campaign with the largest possible advance big gifts.

The UJA Inaugural dinner at a New York City hotel ballroom on the evening of 7 December, with the minimum gift requirement reduced to $\$ 35,000$ to emphasize the concept that this is the amount required to "save a Russiain family" and to produce a larger attendance at the dinner.

The UJA annual conference 8-10 December with Israel's Deputy Prime Minister Yigal Allon as the featured speaker at the saturday night banquet. 
Resumption in January of the resident overseas solicitors' program, with improved arrangements with the communities for more effective utilization of the solicitors.

operation Jet to encompass solicitation of undergivers from small towns by two man solicitation teams.

A special concert in March at Lincoln Center in New York to celebrate Israel's 25th anniversary and to stress the need for increased gifts.

Marking Israel's 25th anniversary with a UJA New York Sunday Times Magazine supplement (12p.; 4 March 1973; $\$ 64,000)$ highlighting UJA efforts in assistance to Israel and its people. [The UJA placed more than $\$ 200,000$ in newspaper ads in 1971.]

An all-star TV network special in prime time with "The Seven Lively Arts in Israel" for its theme. . .

Even more important, naturally, than campaign programs was cash collection of pledges, a perennial UJA problem. At the 1972 retreat the executive committee learned that Jews who had pledged $\$ 103,000,000$ in the 1971 campaign had yet to contribute in 1972, and that while $\$ 11,000,000$ was from those whose campaigns did not begin until the fall, $\$ 92,000,000$ was concentrated in spring campaigns already underway (and mostly concluded). Later in the year the executive committee would learn that the UJA share of local campaigns came to $\$ 265,000,000$ in 1972 , but only $\$ 102,000,000$ was in cash--the reamining $\$ 163,000,000$ in uncollected pledges, a problem to be discussed later. But in June, the committee saw that 1,393 Jews who had pledged $\$ 10,000+$ in 1971 had yet to contribute in 1972. (Not all the news was bad: the executive commitee also learned that of the 3,243 gifts of $\$ 10,000+$ so far obtained $(\$ 140,000,000), 460$ were increases or entries for the first time, and the latter meant $\$ 30,000,000$ in "new" money.)

When the executive committee requested that the professional staff provide a further breakdown of the $\$ 103,000,000$ refered to above, it learned that $\$ 64,000,000$ was concentrated in fifteen cities and more than half of this amount in Los Angeles, New York, and Chicago. The executive commitee then vigorously hammered out a variety of approaches to accelerate cash collection in these cities, including: visits to communities where national leaders never visited before; meetings of UJA executive personnel with executive directors of the largest communities in order to try to change cash collection patterns; a letter from the general chairman, 
urgently appealing for cash, to 20,000 contributors; an intensive national effort to obtain a maximum amount in cash during the six day period in early June marking the anniversary of the Six Day War; telephone cash solicitations made by national leadership from the UJA office. It was obvious to all that, in the words of one executive committee member, the "weeks ahead would require considerable concentration on the five cities."

Furthermore, in response to another query, the executive committee learned that although the UJA had a good collection record in the long run (See Table 9:4), accounts unpaid for all years before 1972 totalled $\$ 89,000,000$ ( $1 / 3$ in the Regular and $2 / 3$ in the Emergency Fund), that $\$ 25,000,000$ was in Cleveland and New York alone, and $\$ 20,000,000$ in Philadelphia, Boston, and Los Angeles. Again the executive committee brainstormed and provided nearly a dozen useful suggestions, including its own "determination" to make "telephone calls for cash" as well as "person to person cash solicitations." In both cases, current and retrospective pledges, the executive committee signalled loudly its own willingness to collect the outstanding cash. It remained convinced that lay volunteers, from the president of a federation and the general chairman of the campaign on down, rather than professional staff members, could best accomplish this difficult task. 12

With the collection of cash came the serious matter of where to allocate the dollars. A perennial topic of discussion of executive committee gatherings was the ratio of local vs. overseas allocations from federated campaigns. As a result of Herbert Friedman's tireless fights, as well as the six Day war and the "War of Attrition" in the years immediately preceding 1972, the UJA enjoyed a favorable ratio in the 1960 s and early 1970 s of about two to one. This meant that about 65 percent of the total campaign dollars were funneled to Israel.

The 1972 gathering found the executive committee deliberating on ways to maintain, if not increase, overseas allocations. It could not know, of course, that after the vibrations of the 1973 War subsided, that is, beginning in 1976, the UJA lost an average of 2.5 percent per annum in the percentage of campaign dollars allocated to the UJA. Instead of the pre-1973 war ratios of two to one, the overseas percentage fell below sixty-forty (see Table 9:5), sometimes crept very close to parity, and in many communities the 
allocations for non-overseas needs actually slightly exceeded the UJA allocation. This is generally conceded by UJA professionals to be a major factor in the creation of Project Renewal, an imaginative vehicle to win back larger amounts for Israel (See chapter ten). 13

This collection and distribution of philanthropic dollars, the UJA felt, depended in part on a tolerant governmental environment as expressed in American tax legislation. The executive committee retreat of 1972 represented the first major effort of the UJA to vigorously involve its lay leaders in the defense and protection of its legal rights. The 1972 threat was more serious than that of Sen. Ellender or Mr. Warburg (See chapter seven), for House and senate bills, introduced and co-sponsored by "liberals" such as Rep. James Corman (D-Cal.), Sen. Edward Kennedy (D-Mass.), Sen. George McGovern (D-S.D.), and Sen. Hubert Humphrey (D-Minn.), would limit the deduction for charitable gifts to only an amount which was above 3 percent of taxable income. Since about $30,000,000$ of the $35,000,000$ taxpayers who itemized their deductions in 1970 contributed less than 3 percent of their taxable income, this would strike at the heart of tax deductible contributions to charity and affect hundreds of thousands of UJA donations. Furthermore, the legislation would reduce tax-free charitable deductions of estates as well as long-term appreciated property, including securities, from 100 percent of the appreciation to 50 percent. Since many of the UJA large gifts were in the form of appreciated property, any such reductions would have enormous impact on "pact-setting" gifts. And finally, the bills would end tax exemption for gifts from estates and bequests to institutions located in other countries--a serious blow to UIA and JDC income.

The executive committee discussed this legislation at lengt $h$, concluded (correctly) that the large number of liberal Congressmen who sponsored the bills probably did not understand fully the harmful effect of their proposals, and resolved to arouse their local leaders to conduct a (successful) vigorous letter writing and, when possible, personal visit campaign in their congressional districts and states. ${ }^{14}$

One executive committee member suggested that this letter writing campaign might prove especially attractive to the wives of the men at the retreat ("they have more time"), and this casual remark opened up the subject of women and the UJA. 
Thus, several months before Jacqueline Levine, a vice-president of the CJFWF stirred 3,000 delegates with her plea for greater inclusion of women in local and national federation boards, 15 the executive committee of the UJA discussed the same issue. The immediate problem which occupied the committee's attention was the attempt by some young leadership cabinet members, and their wives, to open the ranks of the all male young leadership cabinet to women. This 300 man cabinet--virtually limited to those with generous amounts of time (for retreats, conventions, missions, and the campaign) and money (for a high level of giving as well as retreats, conventions, and missions)-zealously guarded its male comraderie and its myth that only men can effectively solicit other men, especially for big gifts.

In the executive committee discussions of this matter it is evident that there was little support for diluting the homogeneity of the young leadership cabinet. Most discussants agreed that the women's division (founded in 1946), and especially its national board, served as a perfectly appropriate format for women who had achieved prominence on the local level and sought national activity, and that a division by sex was neither artificial nor undesirable. Although it was admitted by some that the women's division was a "dead end," i.e. women do not move on to campaign leadership positions, there was agreement that, on the one hand, the women's division, after all, raised significant sums of money (more than 15 percent of campaign gifts) and thus offered genuine prestige, and, on the other hand, that if women pushed hard to enter the campaign cabinet or executive committee the opportunities would be just as numerous directly from the women's division as from the young leadership cabinet. And since the former continued to provide opportunities for feminist expression by creating programs by and for women, this, the men of the executive committee felt, ought to be sufficient for committed women. The records of the retreat reveal that one man suggested the creation of a young leadership group for women, both to offer the prestige of the men's cabinet and to provide younger women with the conraderie of their own sex, age, and interests. While there is no indication of a specific response to this suggestion in 1972, by 1977 the UJA had established a young women's leadership cabinet. 16 
The young women's leadership cabinet, and the many committees delineated above, signalled the distinguishing mark of Mr. Bernstein's stewardship during the 1970s. He spoke frequently about Jewish leadership, or, more precisely, the lack of. it, and the "terrible price we [Jews] have paid throughout history when our community lacked leadership." His conception of the UJA executive vice-chairmanship was, more than anything else, one of identifying, harnessing, educating, and most of all, utilizing leaders.

Bernstein not only carefully expanded the professional staff--involving them especially in organizing the technical plans for various phases of the campaign, recruiting the volunteers, and sustaining the operation and continuity ("maintenance") of the federated national structure--but steadily increased the number and importance of the volunteer sector of the UJA. With considerable dedication these volunteers utilized their skills and experience on the local level, as well as their socio-economic clout, to review the national campaign calendar, solve campaign problems, upgrade contributions, recruit new volunteers, and discover (as well as actually solicit) new contributors. ${ }^{17}$ 



\section{CHAPTER 10 \\ PROJECT RENEWAL}

Not long after his victory in 1977, Prime Minister Begin proposed to the Assembly of the Jewish Agency a massive, five-year, crash program to rehabilitate housing in 160 slum neighborhoods occupied by 45,000 low-income, mostly large families of sephardic origin. The cost, he stated, would be $\$ 1.2$ billion, half to be provided by the Israeli government, $\$ 400,000,000$ by American Jewry, and $\$ 200,000,000$ by world Jewry residing outside Israel and the United States. The neighborhoods, selected by the Ministries of Housing, Labor, and Social Affairs, were largely urban, contained about 3,000 to 8,000 residents each, and had most of the criteria with which to be described as slums (overcrowding, low per capita income, poor housing, large welfare loads). They, and their residents, for years neglected because of more overwhelming problems, were badly in need of renewal and reconstruction.

Why did Begin propose this project of renewal? It was, in part, a political debt. The majority of slum residents were Sephardic Jews, the same Jews who made the Likud victory possible and who had been agitating for socio-economic change for several years. Given the snail's pace at which the Israeli bureaucracy moved, Begin knew how little effective change could occur through normal channels and thus his bold proposal to overcome the traditional Israeli red tape.

This proposal was also a response to a growing concern in American Jewish philanthropic circles about diaspora involvement in overseas allocations and about areas of Israeli society badly in need of improvement. The number of individuals to be helped was put at 300,000, and the call for a consolidated program to provide a network of housing seemed to be exactly what American Jewish communal leaders had been urging throughout the 1970 s with their desire for the development of more concrete channels of involvement in Israeli society. 1

The initial reaction of the UJA and CJFWF in the fall of 1977 was not enthusiastic. Some leaders feared that the regular campaign would suffer with a new line on the card; some questioned financial accountability with sums so large; and some thought it would be wise to promise less, do four or five neighborhoods well, and in the process develop models for 
comprehensive, integrated, physical and social as well as inter-agency cooperation. Others doubted that the Israeli government would be able to sustain a $\$ 600,000,000$ commitment in the face of extraordinary inflation; and still others argued that the renewal of housing alone was too narrow a focus--a comprehensive package of community facilities and social services ought to be joined to a program for new construction. ${ }^{2}$

Most of all, UJA fundraisers were hesitant to allow a side of Israeli life to emerge which had been carefully shielded from American Jewish consciousness in UJA campaign material, although acknowledging "there is a serious socio-economic gap today which...threatens to erode the cohesiveness of the people of Israel." This Israel included hard-core social poblems such as poverty, juvenile prostitution, delinquency, retardation, and drug addiction--all considered non-saleable. Indeed, such a picture had once been presented to American Jews when Eliezer Jaffe, a director of the Jerusalem Muniipal Welfare Department in the early 1970s, convinced Herbert Friedman to allow Jerusalem social workers to take UJA missions on personal visits into the homes of Jerusalem slum-dwellers. The visits where short-lived, as Jaffe later learned, for this was a side of Israel better left out of campaign missions. ${ }^{3}$

$$
\text { Besides the UJA's reluctance to highlight Israel's }
$$
failures, internal and external problems early in 1978 subordinated the renewal program. A widely publicized (and generally unsuccessful) confrontation between a small minority of top, young, lay leaders--Leonard strelitz, the national chairman; Gordon Zacks; Alex Grass--and Irving Bernstein, executive vice-chairman, over the amount of imagination, direction, and skill Bernstein and other "old guard" leaders brought to the UJA, preoccupied the UJA leadership in the early months of 1978. And as Bernstein was successfully defeating an effort to remove him, Israeli leaders attacked the UJA, and its beneficiary HIAS, for "influencing" many soviet Jewish emigrants, once in Vienna, to change their destinations from Israel to America. The UJA, and HIAS, responded that they indeed funded so-called "dropouts," i.e. those choosing not to go to Israel, but that the decision, in every case, was that of the emigrant and was made without pressure. Charges and defenses flew back and forth, however, between World zionist organization/Jewish Agency/Israeli government leaders and 
American Jews, throughout the spring of 1978, and again kept the UJA, entangled. 4

But times were changing, and the idea to combine physical and social reconstruction seemed to make sense to American Jewish and Israeli leaders. As the Jewish Agency began to articulate project Renewal in the spring and suminer of 1978, building housing became only one part of a large and ambitious package of physical and social rehabilitation. Battling unemployment, disease, and illiteracy as well as decaying housing appealed to the UJA executive board, which voiced its support in August of 1978, and in september the UJA Prime Minister's Mission, kicking-off the 1979 campaign year 320 strong, pledged $\$ 11,000,000$ to project Renewal after announcing $\$ 18,000,000$ in regular contributions. Poverty, rather than success stories, had become saleable. ${ }^{5}$

This enthusiasm grew out of not just the physical and social rehabilitation of slum areas, but a much more imaginative concept hammered out by the UJA leadership and Israel in response to an idea generated by Eliezer Jaffe. It consisted of American Jewish communities adopting Israeli slum areas and participating with them in the transformation of neighborhoods. While concrete plans were not yet available, the notion of "twinning" diaspora and Israeli communities, the opportunity for American Jews to utilize their considerable non-philanthropic skills within overseas communities, and the excitement engendered by a government suddenly ready to not only integrate physical and social service planning but to give the poor the tools for their own rehabilitation, was sufficient to evoke gigantic pledges, if not, as we will see, dollars. By November the CJFWF added jts endorsement, stressing the need to turn now from "building a state to building viable communities." But American Jewry hardly needed CJFWF approval, for by the time of the endorsement the largest givers to the 1979 campaign had already pledged $\$ 27,000,000$ to Project Renewal. 6

To implement such an ambitious plan and to channel the expected millions of dollars in cash, a complicated structural process was developed. An Inter-Ministerial Committee composed of an equal number of Jewish Agency executive committee members and Israeli Cabinet members, a reflection of the sensitive politics involved in these choices, selected the target neighborhoods, and then the UJA worked out with specific 
federations the selection of a twin. Some Jewish communities took sole responsibility for an Israeli neighborhood (Nashville: Beit She'an; Englewood: Neve Josef in Haifa; Los Angeles: Musrara in Jerusalem; Birmingham: Rosh Ha'ayin) while other neighborhoods were twinned with a sizeable number of American communities (Hatzor: Barstow, Long Beach, Palm Springs, Sacramento, San Bernadino, CA; Honolulu, HA; Las Vegas, NE; Phoenix and Tucson, AR).

Within each neighborhood that had been twinned, a steering committee served as the vehicle created to maximum citizen participation. While local residents were in every case most numerous, there have also been cabinet representatives, local elected and/or appointed officials, Jewish Agency employees, and delegates from the twin community (advisory) as members of the steering committee. Its job was to propose specific projects-which then needed the approval of a plethora of financial and legal committees in the municipal, national, UIA, and UJA hierarchy, including a Ministerial Committee--and eventualiy to authorize and appropriate the funds within the community. 7

The crucial steps were the proposals generated by the local community and, of course, the raising of funds in the twin community. The UJA submitted the local steering committee's proposals, and its budget, to the appropriate federation after all the steps necessary for approval had been taken. A budget, such as the one Givat Katznelson in Nahariya forwarded to Cincinnati (See Table 10:1), might normally be a rather dry document, but project Renewal committee members from Cincinnati had already come to Israel and worked with the community in formulating the budget. In most cases they had toured the neighborhood, seen the inside of housing, talked with some of the residents as well as emerging neighborhood leaders, discussed the needs of the neighborhood with the project Director, and they would return again to monitor--along with the UJA's conduit, the United Israel Appeal--how the funds were being utilized. When they solicited in Cincinnati for $\$ 38,513$ to fund educational programs for adults, and $\$ 68,900$ to provide a center for the elderly, they had seen adult illiteracy and the isolation of the elderly first-hand. ${ }^{8}$

But Givat Katznelson and Beit She'an and all the other Project Renewal neighborhoods soon discovered that the reported millions of dollars were not being turned from pledges to 
dollars with great speed. In fact, throughout most of 1979 far more complaints and criticisms about project Renewal made headiines in Israel and America than did successes. And with good reason. A carefully prepared confidential study requested by the UJA concluded, after visits to sixteen neighborhoods and several American Jewish communities as well as visits with top-level Israeli officials, what most everyone already knew: the primariy problem appeared to be the inability of Israeli officials to effectively utilize the available funds, or "to cut through red tape and provincial political obstacles," and hence their actions stirred anger in community residents excited by the promises, pledges, and publicity of project Renewal. The municipalities, national government, Jewish Agency, and even diaspora communities could not agree on a division of authority--Housing Minister David Levy, for example, felt that his previously well-protected ministry was threatened by Project Renewal and Jewish Agency encroachment, and unable to yield any control over his domain, for several months early in 1979, Levy forbid his staff to speak with either Deputy Prime Minister Yigael Yadin, who was given Cabinet-level responsibility for Project Renewal, or Eliezer Raphaeli, the Deputy Director General for Project Renewal! The result? Community leaders in Israel complained of concrete results and their counterparts in America could find little evidence of accomplishments a full two years after Begin's proposal was made. Most telling was a report to the Jewish Agency board of governors in the fall of 1979 that although $\$ 60,000,000$ had reportedly been contributed (they meant pledged) to project Renewal by United States Jewry, only $\$ 5,000,000$ in cash would be available by the end of the year. Perhaps Eliezer Jaffe had been correct when he noted in the spring of 1978 that project Renewal was introducing concepts not rooted in Israeli soil:

\footnotetext{
For the Israelis, [Project Renewal] is impractical ... We have no time tested models of how to renovate slum neighbourhoods, of coordinating local, district and national agencies involved, and of integrating social services with housing. 9
}

Israel's runaway inflation did not help project Renewal either in its attempt to establish credibility. In early December of 1979 Finance Minister Hurvitz proposed freezing Israel's share of project Renewal on the (unlikely) grounds that it was a major contributor to inflation. Yadin, as well 
as the Labor and Social Affairs Minister Katz, successfully fought for its continuation-not only on the obvious grounds that it represented but a small expense, but on the basis of its success in involving the people of the neighborhoods directly in the process of planning their own future and deciding on the priorities of their own lives. ${ }^{10}$

Conflicts continued to mar project Renewal fundraising and implementation in 1980 as well. When the Jewish Agency Assembly convened in Jerusalem in June, slum residents and activists led demonstrations outside the meeting, sent an open letter to diaspora leaders vigorously criticizing project Renewal and stating that the "truth" about Project Renewal never reaches American Jews, and even broke into an Assembly session, while speaker after speaker at the plenum, including establishment leaders of the UJA and Jewish Agency from inside and outside of Israel, expressed their impatience with three years of bureaucratic red tape at nearly every one of the early sessions.

World Sephardi Federation president Nessim Gaon, in a speech to the Assembly plenum, called Project Renewal a "time bomb." He noted that the neighborhoods earmarked for renewal "have been paralyzed by a government process that is so complicated that it has virtually halted any programs," and that by plugging steering conmittee's into "highly centralized authoritarian, and bureaucratic networks, each with its own constituencies, and interests," promises have "aroused human expectations but led only to frustration." Teddy Kollek, the mayor of Jerusalem, told Jewish leaders from three American communities (Washington, D.C.; Los Angeles; Baltimore) funding three Jerusalem neighborhoods that the $\$ 5,000,000$ their cities had funnelled into Project Renewal in 1979 and 1980 had not yet been utilized in Jerusalem.

The executive chairman of the Jewish Agency, Arye Dulzin, summed up the frustration so many felt: "The 'cooperation' between government and agency meant not that there is twice as much bureaucracy--but that there is ten times as much." He praised the Jewish Agency, scored the government for its inability to give up any power, and urged a clear separation of authority between the government and the Jewish Agency, so that each would have its own sphere of control and expertise, to which the Deputy Prime Minister Yadin responded in a word which summed up the government attitude: "absurd." 
Nevertheless, the Jewish Agency Assembly did decide to combine all the units of the Jewish Agency dealing with Project Renewal into a single, full-scale department in order to resolve the bureaucratic mess. This, at best however, still left the question of prestige among government ministers and ministries a serious obstacle to progress. And these questions were many, for the government, through appropriate ministries (Health, Education, Housing, Finance), zealously retained responsiblity for all areas that traditionally belonged to it: parks, schools, housing, etc. This lack of coordination and the inter-departmental preoccupation with territorial sovereignty over service had long been pervasive in Israeli society, and continued to greatly hinder Project Renewal implementation. 11

Complaints and frustrations continued throughout the fall of 1980. Jerusalem and Tel Aviv were the sights of mock "funerals" for project Renewal staged by slum-dwellers from numerous communities, while the manager of Project Renewal in Ashkelon stated: "The bureaucracy is horrendous and the implementation of ideas takes far too long; projects which were approved in July 1979 have yet to get off the ground." In october Eddie Gedalof, Project Renewal director of two Jerusalem neighborhoods, resigned, having concluded that there "was no possibility of making significant changes" after a little more than one year on the job. He took the position, excited by the notion of helping slum residents plan from the "bottom up," but was frustrated by having projects put into the hands of "the same people who had been working in the Establishment for decades." The result was "no structural change which would transfer authority to the neighborhood" and hence a feeling among the residents that "there's nothing I can do." Gedalof had high hopes for Project Renewal, but his experience in Jerusalem with the government and Jewish Agency bureaucracies convinced him that everything about the Israeli government was centralist, bureaucratic, and power-hungry, and that project Renewal was "put into the hands of those who had been centralizing all along." 12

Gedalof had some thoughts on the twinning concept, the aspect of Project Renewal which particularly excited American Jews. He felt that the quality of contact was only superficial, with project Renewal staff spending time taking tour groups from America around run-down neighborhoods. To Gedalof, these 
tourists became a sort of joke in the nieghborhood, people who stared but never seemed to get involved. On this last point, Gedalof was perhaps correct in terms of 1978 and 1979, but late in 1980 American Jewish involvement was not only increasing, it was the primary catalyst for the more optimistic reports of Project Renewal which began to appear in 1981. Surely the decision to admit project Renewal could not be accomplished in five years as well as the role of Yehiel Admoni, the new Director General of project Renewal for the Jewish Agency, were significant, but hardly had Admoni taken over the floundering program when one began to notice that the involvement and excitement of American Jews over the possibilities of direct. involvement in Project Renewal--from participation on steering committees to sharing talents and skills (business, coaching, medical and dental, social work, city planning, etc.)--began to correspond to the early visions of what it might accomplish not only for diaspora-Israeli interaction but for the tens of thousands of Israeli families whose hopes had been so heightened. 13

By late 1980, and steadily through 1981, dozens of American Jewish communities, through their project Renewal representatives, began to meet face-to-face with renewal neighborhood residents for three to five days of neighborhood meetings and budget consultation. Despite the original thrust of the program, through 1978, 1979, and even 1980, "diaspora community consultation" had been only a late stage--both on UJA charts ("Project Renewal Decision Process") and in reality-of the decision process, coming even after Interministerial Comittee approval. For slum residents used to government paternalism and benevolence, the sense of active involvement and partnership in neighborhood decisions--organizing, forming a council, taking an active role in identifying problems, devising programs to resolve them, setting priorities for implementation-was novel, but for American Jews too the partnership offered a vehicle for personal involvement and began to create a dimension in the diaspora-Israel relationship never offered before. As American Jews moved from charity to involvement, found tangible reasons for investment in and visits to "our community" in Israel, and began to appoint and maintain their own representatives to keep communities moving, Project Renewal began to capture the imagination of givers in ways previously unavailable. One member of a midwestern 
Project Renewal committee visited the community's twinned neighborhood where 300 of the 2,000 families in the neighborhood still lived in temporary pre-fabricated huts put up in the 1950s and 200 families lived under conditions of extreme overcrowding, i.e. more than three persons to a room. After conversations and activties with some of the residents, she had this experience:

My last night in the neighborhood, I was walking with a friend who works with the youth. We could hear Hatikvah being played from TV's in the apartments as the station signed off for the night. It was appropriate--Hatikvah, hope. We are part of that hope. 14

In addition to the type of intensive and early-stage diaspora consultation which more and more led to such hopes, 1981 opened with a plethora of additional project Renewal programs. More than 1,000 community leaders without formal academic training were selected for a combined work (neighborhood)-study(university) program which obligated them to repay each year of subsidized study with a year of work and residence in a Project Renewal neighborhood. Kindergarten teachers, parents, and children from project Renewal neighborhoods joined in work and discussion sessions at homes to foster more positive behavior and attitudes toward education and to help prepare children for school, while the Perach tutorial program brought hundreds of university students into Project Renewal neighborhoods to tutor elementary school children. Siach sought to identify pre-school age children with behavioral, physical, or emotional problems, while project Renewal funds were also being used to help fund sixty Tehila learning centers to combat adult illiteracy. As these programs steadily came to the attention of American Jews, support for Project Renewal appeared to be increasing. 15

Cash collections still plagued project Renewal, despite the reports of generous pledging. Very little of the $\$ 11,000,000$ pledged at the Project Renewal kick-off in the fall of 1978 was ever turned to cash, and, as mentioned above, despite announcements of $\$ 60,000,000$ in total pledges by the fall of 1979--including $\$ 10,000,000$ in pledges from the Prime Minister's Mission of September 1979--at the end of that year only $\$ 5,000,000$ in cash had become available, and by March of 1980 only $\$ 6,600,000$. While Robert Russell, chairman of the national project Renewal committee, could announce that Project 
Renewal pledges totalled nearly $\$ 100,000,000$ in April 1981, he reported that on $1 y \$ 16,000,000$ in cash had been collected since 1978: Three months later David Hersch, the national director of Project Renewal, assured me that $\$ 1,000,000$ had been flowing to UJA headquarters every month during 1981, and in october the UJA claimed $\$ 3,000,000$ each month arrived in New York. This still remained, however, less than Israel spent each month. ${ }^{16}$

More ominous still: in August 1981 the entire Project Renewal operation in Israel moved from the jurisdiction of the Prime Minister's office to that of the Ministry of Housing where David Levy, never known for his spirit of flexibility and cooperation, took control. The Ministry's inmediate proposal was to recommend reducing Israel's commitment to match, dollar-for-dollar, diaspora funds $(\$ 600,000,000$ from Israel; $\$ 600,000,000$ from world Jewry), as it had been doing for several years, and substitute a reduced allocation which would be a fixed proportion of its annual budget. In addition, the Ministry also suggested greater centralization of decision making by having all plans and budgets approved only once--by local authorities in a committee comprising officials from the government, local authority, and the steering committee. UJA leaders seemed convinced that this would reduce the duplication in approval of renovation schemes, but unsure whether simultaneously project Renewal could maintain its unique combination of neighborhood control and initiative. If so, perhaps in the long run project Renewal might finally fulfill some of its grand expectations. ${ }^{17}$ 
CHAPTER 11

PROBLEMS AND PROSPECTS

Writing in 1981, Melvyn Bloom, the assistant executive vice-chairman and national campaign director of the United Jewish Appeal, stressed the major desiderata of American Jewish philanthropy: big gifts. Although aware that perhaps as many as half of all adult Jews in the United States make no contribution of any amount to a federated campaign or the UJA, Bloom did not stress the need to increase the level of mass giving. He knew, of course, that in the largest cities, even if one included gifts as high as $\$ 1,000$, all of these contributions accounted for less than 20 percent of a campaign while one-tenth of one percent of the contributors provided 25-30 percent of the total. Indeed, in recent years, 5 percent of the givers in several communities have accounted for more than two-thirds of the receipts, and less than 10 percent have contributed 85 percent: But the 7,000 "big gifts" in the 1978 campaign $(\$ 10,000+)$, yielding 45 percent of the $\$ 474,000,000$ total, were not a cause for rejoicing, for the number of big givers remained fairly constant throughout the late $1970 \mathrm{~s}$. Thus the ambitious effort, as the new decade opened, to find, cultivate, and upgrade potential generous benefactors. 1

This helps us understand the establishment of UJA committees for every big gift level. The "\$10,000 to $\$ 49,999$ Committee" counted more than 6,000 gifts in 1980 ; the Target Committee $(\$ 50,000-\$ 99,999)$ produced over 700 gifts (vs. only 649 in 1979); the Hineni Committee (\$100,000-\$249,999) tabulated 432 contributors; and while the International Leadership Mission did not reveal the number of $\$ 250,000+$ gifts it realized in 1980 (35 arrived in $1977^{2}$ ), it developed new techniques and programs to try to lure some Hineni gifts into the higher category. 3

The UJA strategy, and that of its fundraising arms, the federations, thus remained unchanged. Finding ways to identify big givers, and then to induce big givers to make big gifts, is what American Jewish fundraising is really about, and wht professionals spend most of their time and energy doing. Both Herbert Friedman and Irving Bernstein have explained that when needs dramatically increased, such as in 1967, 1973, or with the initiation of Project Renewal, the object of staff and lay 
leaders was to convince big givers to increase the size of their contributions proportionately. This made perfect sense, for by definition, the size of small givers' gifts cannot be increased much since (we assume) they are indeed without much to give, and the most efficient use of time and talent would suggest that increasing a $\$ 17,000$ gift to $\$ 18,000$ is more expeditious than cultivating ten new gifts of $\$ 100$ each. At least in the short run. ${ }^{4}$

Therefore, in most medium and large Jewish communities, where 90 percent of the givers contribute less than $\$ 1,000$, the fundraising apparatus largely gives only token attention to these small givers. This is partially a decision based on maximizing results, and partially the result of the fact that the philanthropic structures in most communities are overwhelmingly plutocratic, with priorities, and allocations, directly or indirectly dictated by the big givers. 5

This had led a growing number of small givers, lacking a strong voice in an organization largely controlled by the donor class, to seek new ways of collecting and distributing money. As the 1980s began, more than two dozen identifiable Tsedakah collectives--small groups of Jews who came together to raise their own monies and to determine, in as democratic and egalitarian a manner as possible, how to allocate these monies--existed in America. Neither their sums nor their size posed any threat to the UJA/federation, but they offered to their followers a sense, on the part of the smallest of givers, of participation and control. 6

Even more, these collectives provided the opportunity to fund projects that a national organization such as the UJA considered too risky or too small. Danny Siegel's Tsedakah Chevra, well-known to readers of Moment, distributed $\$ 12,720$ in 1980, and seven allocations consisted of gifts of $\$ 100$ or less, including $\$ 100$ to Rachel Gur-on's Jerusalem workshop for people with cerebral palsy, $\$ 14$ for a kindergarten scholarship, and $\$ 80$ for a large English sign over Yad Sara, a center for more than 300 volunteers in Israel who lend out medical supplies at no cost to people in need. Here, more so than in an organization which collects hundreds of millions of dollars annually, the child who sent $\$ 3.17$ from a piggy bank felt that the smallest sums mattered. 7

The New Israel Fund, a San Francisco based collective with national appeal, similarly has been able to fund smaller 
groups, but also to use its resources to support agencies, organizations, and associations largely ignored by the UJA. Its distribution of more than $\$ 215,000$ from January 1980 through June 1981 included nearly 25 percent of its funds to innovative services, nearly 30 percent to civil rights groups, nearly 25 percent in the area of women's rights, 15 percent to community action, and more than 10 percent to Arab-Jewish relations. (See Table 11:1) Perhaps its heavy support of feminist and civil rights causes reflected the abundance of progressive or liberal Jewish contributors, but the uniqueness and attraction of the group consisted of not only the funding of those attacking Israel's toughest problems but the opportunity for donors to earmark, once a primary list had been funded, their dollars for their favorite projects. An Israeli board of directors, working closely with the American board and chaired in $1981 / 82$ by Eliezer Jaffe, made the decisions about where the greatest needs were in Israel, which projects deserved the highest priority, and how the money was being used, but a careful attempt had been made to develop an equal partnership between donors and grantees, Israelis and Americans.

NIF leaders noted that their 500 donors were not only those who had been giving to a federated or UJA campaign and had switched (or supplemented) their UJA gift, but Jews, with a strong commitment to progressive social causes in the U.S., who had previously not contributed to traditional Jewish philanthropy at all and who did not appear particularly moved by the principle of organized Jewish philanthropists that to raise money one must first raise Jews. These Jews--and even the UJA estimates they are nearly as large a number as those who do give--remain a source of mystery to the leaders of Jewish philanthropy. ${ }^{8}$

Less mysterious, and more worrisome, has been the welldocumented changing demographic structure of the American Jewish community and its long-term implications for fundraising. Children of the entrepreneurs have been entering the professions (especially those with poor giving levels) in significant numbers, and the myriad of family-owned businesses (Jewish) have been increasingly swallowed by conglomerates (non-Jewish). Both of these developments, when combined with the Jewish population's steady residence in the lowest ecological fertility category bode poorly for the future of Jewish giving and have begun to alarm UJA and CJFWF leaders. ${ }^{9}$ 
Providing, however, much more cause for confidence than distress, has been the growing number of "young leaders" actively emerging in the late $1970 \mathrm{~s}$ and early 1980s. Their participation on UJA missions and continuing involvement in local campaigns have highlighted their commitments to Jewish philanthropy and Jewish survival. This optimism is the result not just of the success of the 250 strong young leadership cabinet--influential and wealthy young ( 25 to 40$)$ men who display leadership potential and a willingness to work hard--and its imitation, the young women's leadership cabinet, for both the YLC and YWLC are national, elitist, and relatively closed. Their successes are many, to be sure; the YLC set $\$ 2,100,000$ as its 1981 campaign goal while the women raised more than a quarter million dollars in the same campaign; the YLC, at its Chicago retreat, pledged $\$ 2,034,230$ to the 1982 campaign plus $\$ 1,409,680$ to project Renewal while at the young women's leadership cabinet retreat in Dallas 120 women pledged $\$ 275,803$ and $\$ 138,430$ to the 1982 regular and Project Renewal campaigns respectively; while an experimental national singles mission of 400 committed itself to nearly $\$ 500,000$ for the 1982 campaign. But it was on the local level that the more than 4,600 American Jews who travelled on UJA missions in 1980 seemed to make the greatest impact, especially in the cadre of young leaders rapidly developing in communities all over the country. 10

This represented, of course, a reward for the UJA-CJFWF effort, nationally, regionally, and communally, to recruit and train promising young leaders. The goal has been not only to upgrade gifts, but to motivate these young leaders to become the next generation of campaign leaders. Our own brief survey of recent young leadership mission participants from five scattered communities around the country confirmed this accomplishment. Il

Parenthetically, it is of interest to note that more than two-thirds of the fifty-two respondents (twenty-four couples and four singles) felt that either the elitist nature of the young leadership missions, the opportunity for upward mobility, or the ego satisfactions involved in the hobnobbing with luminaries was the primary catalyst for joining the missions. But an equally large percentage (nearly 65 percent) claimed that its primary notivation after the mission had become the giving and raising of funds as well as the spreading of the 
positive values of Jewish philanthropy (Jewish security and continuity) among the masses of Jews in the community. Put differenty, a substantial percentage of the mission participants believed in the product they were selling--Jewish welfare and survival--and were eager to convince others of its value. More often than not this was occuring, again to the delight of the professionals, through active participation on campaign commitees, especially solicitation. And this is what has provided evidence of confidence for the continued vitality of Jewish fundraising.

Another reason for optimism among UJA professionals was the fact that 1980 represented the first year since the Yom Kippur War in which the percentage of communal funds allocated to the UJA did not decline--and even increased by a tiny fraction. (See Table 9:5) To the UJA this resulted from tireless campaigns, fought by professionals and regional/local lay leaders, to convince allocation committees to increase (or at least not decrease) overseas $(=$ UJA) percentages. These campaigns, which took the form (and still do) of vigorous presentations on the coinmittee level and aggressive attempts to lock-up pre-campaign budgeting agreements with every major community, achieved modest success, and the prelininary figures for the 1981 campaign $(\$ 550,000,000)$ provided grounds for continued optimism. With a large and committed group of lay leaders across the land, the UJA entered the $1980 \mathrm{~s}$ with an abundance of strength and confidence.

And even more. Many students of "civil religion" have expressed, in one way or another, agreement with Irving Bernstein's remark that "the UJA is, through Israel, America's Jewish religion." Bernstein has argued that the "practise" of Judaism is "not by prayer, but through philanthropy."12 With well over 1,000,000 Jews contributing their dollars annually, through their local federated philanthropy arive, to the UJA, and more than 100,000 each year participating on a committee or in a solicitation, Bernstein may be right. For there is no doubt that the intensity of commitment that a growing number of Jews bring to their UJA work parallels that once reserved by many for fulfilling the commandments. Whether or not it is helpful to understand this fervor in terms of a "civil Jewish" ethos or not, it cannot be denied that the United Jewish Appeal in 1982, with its legion of supporters, muted critics, and the second highest peace-time campaign ever just completed, nears its forty-fifth anniversary in marvelous health. 



\section{NOTES TO CHAPTER 1}

l Palestine Post, 31 January 1939.

2y. Bauer, My Brother's Keeper: A History of the American Jewish Joint Distribution Committee 1929-1939, Philadelphia, 1974; 0 . Handlin, $A$ Continuing Task: The American Jewish Joint Distribution Committee 1914-1964, New York, 1965; J. C. Hyman, "Twenty-Five Years of American Aid to overseas: A Record of the Joint Distribution Committee," American Jewish Year Book [AJYB] 41 (1939-1940): 141-179; M.A. Leavitt, The JDC Story: Highlights of JDC Activities 1914-1952, New York, 1952, pp. 4-12; H.S. Linfield, The Communal Organization of the Jews in the United States, 1927, New York, 1930, p. 110; The Jewish Situation in Eastern Europe and the Work of the JDC, a Joint Report by Jacob Billikopf and Dr. Maurice B. Hexter, n.p., 1926; Report of Dr. Bernhard Kahn, European Director of the American Jewish Joint Distribution Committee, n.p. 1926.

${ }^{3}$ H. Agar, The Saving Remnant: An Account of Jewish Survival, New York, 1960, pp. 47-51; M. Berman, The Bridge to Life, Tel Aviv, 1970, pp. 19-20, 31, 33, 41; D. $\bar{A}$. Brown, The New Exodus: The Story of the Historic Movement of Russian Jewry Back to the Soil, New York, 1925; Linfield, Communal Organization, pp. 115-116; H. Lurie, An Heritage Affirmed: The Jewish Federation Movement in America, Philadelphia, 1961, pp. 136-137; E. Morrissey, Jewish Workers and Farmers in the Crimea and Ukraine, New York, 1937, pp. 120-143; Founding of a New Life for Suffering Thousands, a Report of Dr. Joseph A. Rosen on Jewish Colonization in Russia, Philadelphia, 1925; The Present Status of Russian Jewish Agricultural Colonization and the Outlook, a Report by Dr. Joseph A. Rosen, n.p., 1926.

For a concise report on the zionists' attitude toward the JDC, see the New York Times [NYT], 26 october 1925. For useful summaries of JDC fundraising in the United states during the $1920 \mathrm{~s}$, see NYT, 23 October and 14 November 1927. For useful summaries of zionist fundraising in America during the 1920s, see AJYB $27(1925-1926): 142$, NYT 15 February 1925, 18 october 1926,9 December 1927, and $\underline{A J} \overline{\mathrm{YB}} 28(1926-1927): 128$. On UPA successes in relation to previous independent fundraising by Zionist organizations in America, see NYT 30 November and 26 December 1925, 10 January 1926, 13 July and 31 october 1927, and AJYB 28 (1926-1927): 147-148 and 29 (1927-1928): 115-116, as well as United Palestine Appeal, Rebuilding the Land of Israel, New York, 1927, United Jewish Appeal Papers, Box 3, American Jewish Historical Society, Waltham, Mass.

$4_{\mathrm{H}}$. Solow, "The Era of the Agency Begins," Menorah Journal 17:2 (November, 1929): 111-125; B. Halpern, The Idea of the Jewish state, Cambridge, Mass., 1969, 2nd edition, pp. 194-195. Actually, David Brown did head a very successful United Jewish Campaign in 1926, but it was little more than a JDC fundraising effort. See United Jewish Campaign News: Chicago Conference Special, 11 october 1926, UJA Papers, Box 2.

5 J.c. Hurewitz, The struggle for Palestine, New York, 1950, pp. 40ff., 110f.; S. Chinitz, "The Jewish Agency and the Jewish Community in the United states," M.A. thesis, Columbia University, 1959. 
6 Jewish Daily Bulletin [JDB], 19 January 1930; AJYB 32 (1930-1931): 69-70; NYT, 25 February and 11 April 1930; An Alliance of American Israel for All Israel, The Purposes of the Allied Jewish Campaign, October, 1930, pp. 4-24, UJA Papers, BOX 1.

${ }^{7}$ program of the National Conference at Washington, D.C. of the Allied Jewish Campaign, 8-9 March, 1930, UJA Papers, Box 1; Der Forverts, 8 March 1930; Der Tog, 8 March 1930; JDB, 9-11 March 1930; NYT, 10 March 1930.

$8 \mathrm{JDB}, 25$ December 1930, 27 January and 24 March 1931; AJYB $32(1930-1932): 70$; NYT, 26 January, 9 February, 29 June, and 10 November 1931.

9 United Jewish Appeal, Questions and Answers about the United Jewish Appeal, New York, 1935; AJYB 41 (1939-1940): 177; NYT, 21 September, 1934; Council of Jewish Federations and Welfare Funds [CJFWF], Notes and News 21 (24 May 1934) and 22 (29 June 1934); AJYB 36(1934-1935): $142-143$ and 37 (1935-1936): 213; Program, Night of Stars, Yankee Stadium, 1934, UJA Papers, Box 3; What is the UJA: Why Does it Ask for $\$ 3$ Million? (A Guide for Campaign Workers and Contributors), [1934], UJA Papers, Box 3; This Problem Must be Met: \$3 Million in 1934, UJA Papers, Box 3 .

10 Louis Lipsky, Telegram to Eliezer Kaplan, 6 February 1935, Eliezer Kaplan Papers, S/53/331, Central Zionist Archives, Jerusalem; New Palestine [NP], 4 October, 31 May, and 23 July 1935; AJYB 38 (1935-1937): $211-213 ;$ NYT, 23 March and 23 March 1934.

IIUnited Way of America, People and Events: A History of the United Way, Alexandria, Virginia, 1977, pp. 25, 43-56, 58; J. Jacobs, "The Federation Movement in American Jewish Philanthropy," AJYB 17 (1915-1916): 159-198.

12Lawrence Tisch, Interview with Marc Lee Raphael, 30 May 1978; Jewish Telegraphic Agency [JTA] Cable Dispatches, 30 October 1935 .

$13 \mathrm{JTA}$ Cable Dispatches, 30 October 1935; AJYB 37 (1935-1936): 213; NP, 1 November, 8 November, 29 November, and 3 April 1936; NYT, 30 October 1935.

14 AJYB 39 (1937-1938): 244-245 and NYT, 27 June 1936. The most enduring innovation during these campaigns was Henry Montor's "novel and stirring method to stimulate the American Jewish consciousness" by having several "big givers" tour other cities and solicit therein together. See Minutes of a Meeting . . 9 March 1937, Kaplan Papers, S/53/374.

$15 \mathrm{NYT}, 3$ January 1937; Minutes of a Meeting. . ., 22 November 1938, Kaplan Papers, S/53/374.

$16_{\mathrm{AJYB}} 41$ (1939-1940): 205; CJFWF, Notes and News 53 (11 January 1939). The CJFWF proposal, together with Kristallnacht, came in the midst of acrimonious discussions between the JDC and UPA over 1939 allocations. The UPA convinced the Jewish Agency to submit a $\$ 10$ million budget for 1939--\$7 million of which would have to come from American Jewry--in order to compete with the expected JDC announcement of an $\$ 8$ million quota. As Montor noted in a cable to 
Jerusalem, "our foes are preparing feverishly." Henry Montor, Telegram to L. Herrmann, 9 October 1938, Kaplan Papers, $\mathrm{S} / 53 / 312$.

17W.J. Shroder, "A Three-in-One Campaign," CJFWF Papers, American-Jewish Historical Society; CJFWF, Notes and News 53 (11 January 1939): 3-4, 64 (2 December 1940), and 65 (15 January 1941); Minutes of a Meeting..., 9 December 1938, Kaplan Papers, S/53/374.

18AJYB 42 (1940-1941): 279-281; Collection Manual of the UJA for Refugees and Overseas Needs, New York, 1939, p. 2; The Refugees: Four Talks by Abba Hillel Silver and Jonah B. Wise, 1939, UJA Papers, Box 3; Humanity on Trial: Text of CBS Radio Address by Professor A. Einstein, Honorary Chairman, UJA 1939, UJA Papers, Box 3. The 1939 campaign concluded disappointingly despite the widespread use, for the first time, of pledges rather than cash as campaign contributions.

19 Minutes of a Meeting of Negotiation Committees. . ., 18 December 1939 and 3 January 1940, Kaplan Papers, S/53/374.

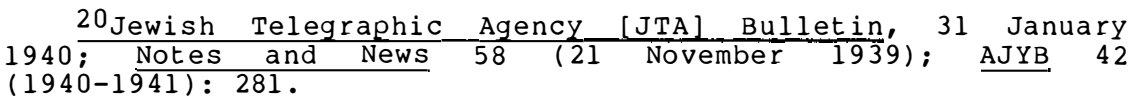

21JTA Bulletin, 5 February 1940; Reconstructionist 24 (24 January 1941); Notes and News 63 (11 November 1940); AJYB 43 (1941-1942); 94-96; JTA Bulletin, 24 December 1940; American Jewish Joint Distribution Committee, Aid to Jews overseas: Report for 1939, With a Resume of the First Six Months of 1940, New York, 1940; Statement by the National Chairmen, 1940 United Jewish Appeal $\$ 23$ Million Campaign, UJA Papers, Box 3. The best analysis of the JDC-UPA conflict is in D.M. Friedman, Inguiry of the UJA, a Report to the Allotment Committee of the UJA of 1940, New York, 1941 .

22JTA Bulletin, 27 December 1940; AJYB 43 (1941-1942): 95; Abba Hillel Silver, Letter to Paul Baerwald, 28 November 1940, Kaplan Papers, S/53/274, and Dr. Georg Landauer, Letter to Eliezer Kaplan, 29 January 1940, Kaplan Papers, S/53/347.

23 The final 1940 United Jewish Appeal allocations gave the NRS $\$ 3.5 \mathrm{milli}$ ion and the UPA $\$ 2.9 \mathrm{million}$.

$24 \mathrm{JTA}$ Bulletin, 17 February 1941; Reconstructionist. 24 (24 January 1941); Congress Bulletin 8:2 (10 January 1941) and 8:5 (31 January 1941); Abba Hillel Silver, Letter to Eliezer Kaplan, 7 March 1941, Kaplan Papers, S/53/374. The most insightful analysis of the UPA leadership and its strategies through late 1940, fom a very candid insider, is to be found in Kurt Blumenfeld, Letter to Dr. A. Hantke, 16 September 1940 and 20 December 1940, Kaplan Papers, S/53/397.

25 Congress Bulletin $8: 5$ (31 January 1941); National. Jewish Monthly 55:7 (March, 1941); Notes and News 66 (19 March 1941); Minutes of a Meeting. . ., 25 February 1941, Kaplan Papers, S/53/335; NYT, 27 December 1940 and 6 January 1941. For extensive details on the UPA's independent campaign, see Minutes of a Meeting. ... 26 February 1941, pp. 1-2, Kaplan Papers, S/53/347. 
26"Turn Spotlight on Budgeting," Notes and News 64 (2 December 1940); JTA Bulletin, 4 February 1941; National Jewish Monthly 55:7 (March, 1941). On the General Assembly, see especially Abba Hillel Silver's angry perceptions in Minutes of a Meeting. ... 25 February 1941, pp. 3-4, Kaplan Papers, $\mathrm{S} / 53 / 335$.

27 Reconstructionist, 24 January, 21 February, and 18 April 1941; Congress Bulletin 8:7 (I4 February 1941).

${ }^{28}$ Congress Bulletin $8: 6$ (7 February 1941), $8: 8$ (21 February 1941), 8:9 (28 February 1941), 8:10 (7 March 1941); Notes and News 66 (19 March 1941); Palestine Post, 9 March 1941; NP, 31 January 1941; United Palestine Appeal, who Shall Distribiute American Jewry's Funds? The Democratic versus the Oligarchic Procedure, New York, 1940.

29JTA Bulletin, 17 February 1941; Palestine Post, 15 october 1941; National Jewish Monthly 55:6 (February, 1941); NYT, 16 February, 28 February, 9 March 1941; Contemporary Jewish Record 4:2 (April, 1941): 179; Minutes of a Meeting -. - $5 \mathrm{March} 1941$, Kaplan Papers, S/53/335. There remains no doubt that sustained waves of protest, from pulpits, organizations, individuals, and especially the Anglo-Jewish press, greeted the failure of the UJA partners to agree upon a 1941 campaign.

30JTA Bulletin, 10 March 1941; National Jewish Monthly 55:8 (Apri1, 1941); Congress Bulletin 8:1l (14 March 1941) and $8: 12$ (21 March 1941).

31 It should be noted that the NRS guarantee in 1940 was $\$ 2.5$ million from the UJA, and $\$ 1.0$ miliion from the UJA of Greater New York.

${ }^{32}$ Congress Bulletin 8:12 (21 March 1941); Notes and News 69 (22 October 1941); Palestine Post, 7 March 1941. The 8th Annual "Night of Stars" featured 1,000 entertainers and was the biggest yet; see NYT, 26 and 27 November 1941. On the JDC unhappiness, see Minutes of a Meeting. . . 29 October 1941 and Minutes of a Meeting..' 9 November 1941, Kaplan Papers, $\mathrm{S} / 53 / 374$.

\section{NOTES TO CHAPTER 2}

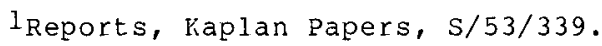

${ }^{2}$ Contemporary Jewish Record 5:6 (December, 1942): 627, $6: 2$ (April, 1943): 170, and 6:6 (December, 1943): 639 .

3E. Ginzberg, Report to Anerican Jews on Overseas Relief, Palestine and Refugees in the United States, New York, 1942, pp. 11-13; Contemporary Jewish Record 5:2 (April, 1942): 187, Y. Bauer, American Jewry and the Holocaust: The American Jewish Joint Distribution Committee, 1939-1945, Detroit, 1981.

4 United Palestine Appeal, Yearbook 1944 and Yearbook 1945; Ginzberg, Report, pp. 13-22.

5United Palestine Appeal, Report 3:10 (October, 1942); "Balance Sheets of a Year of Achievement 1943," and "Balance 
Sheets of a Year of Achievement 1944," United Israel Appeal Papers, Box 1, American Jewish Historical Society; Ginzberg, Report, pp. 23-29.

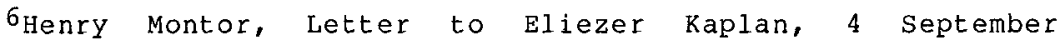
1942, and Henry Montor, Letter to Eliezer Kaplan, 19 October 1944, Kaplan Papers, S/53/379.

7 Minutes of a Meeting. . ., 14 December 1943; Minutes of

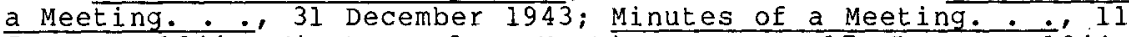
January 1944; Minutes of a Meeting...'17 January 1944; Minutes of a Meeting...' 24 January 1944, Kaplan Papers, $\mathrm{s} / 53 / 314$. For Montor's allocation battles with Harold Linder, the man he called the JDC "professional tough," see Henry Montor, Oral Interview with Jeff Hodes, 14 October 1975.

8UPA, Report 5:2 (February, 1944). See also $5 / 53 / 379$ for clause six of the 1944 agreement, and HKW, Letter to Henry Montor, 31 August 1944, Kaplan Papers, S/53/373.

9UPA, Report $3: 1$ (January, 1942); NYT, 16 January 1941, p. 19, 25 February 1941, p. 46, 9 March 1941, p. 24, 28 Apri1 1941, p. 17, 7 May 1941, p. 17, and 27 November 1941, p. 24.

10UPA, Report 2:8 (October, 1941): NYT, 17 May 1942, p. 29, 9 March 1943, p. 42, 17 February 1944, p. 15; UJA Campaigner $2: 1$ (February, 1943), 2:3 (November, 1943); NYT, $\frac{19}{26}$ November 1941, p. 28, 28 Eebruary 1942, p. 8, and 17 February 1944, p. 15 .

$11_{\text {NYT }}, 26$ February 1945, p. 21, and 1 March 1945, p. 38. The $19 \overline{44}$ split was $60-40$ in favor of the JDC.

12 Special Notice, 18 April 1945, UPA Proposes Unconditional Arbitration for Reconstitution of UJA, UJA Papers, Box 1; NYI, 4 June 1945, p. 32, and ll June 1945, p. 18; Minutes of a Meeting._..' 19 October 1944, Kaplan Papers, $\mathrm { S } / 5 3 \longdiv { 3 2 9 }$.

13 Henry Montor, Oral Interview with Jeff Hodes; $C$. Shulman, "Fundraiser Par Excellence," National Jewish Monthly, (March, 1969): 28ff.

140 field reps, see UJA Papers, Box 2; and UJA Campaigner 3:1 (29 February 1944) and 3:3 (June, 1944).

15 Henry Montor, Letter to Marc Lee Raphael, 18 January 1981; UJA, An Approach to the 1941 Campaign: What Should be the Constructive Keynote for Welfare Fund Campaigns, UJA Papers, Box. 2 .

\section{NOTES TO CHAPTER 3}

IThe nineteen minute "Battle for Survival" (RKo Pathe, Inc., 1946), narrated by orson Welles, captured this UJA conference on $f i l m$, while the professional head of the UJA called it, "the most extraordinary Jewish gathering in our history." Henry Montor, Letter to Charles Morris, 31 December 1945, Kaplan Papers, S/53/335.

2 Henry Montor, Letter to Marc Lee. Raphael, 19 February 1981. More precisely, the campaign target was $\$ 103,000,000$, 
and it was to be divided as follows: $\$ 58,000,000$ for the Joint Distribution Committee, $\$ 43,000,000$ for the United Palestine Appeal, $\$ 1,000,000$ for the National Refugee service, and $\$ 1,000,000$ for the Jewish Welfare Board. In practice, however, the goal was always referred to as $\$ 110,000,000$.

3summary of Collections, 1939-1945, Exhibit 1, Schedule 1 , p. 17 of Klein, Hinds \& Finke, C.P.A.'s, Audit of 14 March 1946, Kaplan Papers, S/53/339.

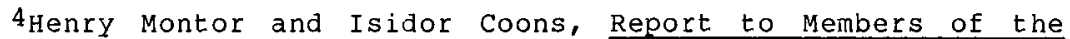
National Campaign Council (=Montor, Report), 1 July 1946; NYT, 17 December 1945 and 1 February 1946. The UJA assigned quotas, or goals, to 108 communities on the eve of the campaign; these quotas, with the 1945 pledge of each locale, are in Tabulations of Major and Secondary Communities with Statistical Information for Quota Study, Kaplan Papers, $S / 53 / 373$.

5Montor, Report, 28 February 1946; NYT, 25 February 1946; Report on Initial Gifts to National Campaign Executive Committee of the UJA, submitted by Edmund I. Kaufmann, 16 May 1946, Kaplan Papers, S/53/379.

6Montor, Report, 1 May, 8 May, 4 June, 1 July, and 24 September 1946 ; Special Report, 8 July 1946, Montor to National Campaign Council; Montor and Coons, Report to National Campaign Executive Committee of the UJA, 16 May 1946, Kaplan Papers, S/53/379.

7Montor, Report, passim., Kaplan Papers, S/53/379; Henry Montor, Letters to Marc Lee Raphael, 17 January and 19 February 1981. For a comparison, nearly three decades later, and the enduring influence of Montor, see UJA, "DO's \& Don'ts of Personal Solicitation," n.d.; NYT, 5 May 1974; and Columbus Jewish Federation, "Notes on How to Solicit," 1980, CJF.

${ }^{8}$ The broadcast was heard in dozens of cities.

9 In May, the presidents of the AFL and CIO jointly urged UJA support; see NYT, 27 May 1946.

10 The two ads used in community after community were "Who Shall Live and Who shall Die" (a pair of appealing hands recite the story of Jewish misery and the need for action) and "Dear Children: We shall not Let You Dien (three pitiful kids recount the plight of 150,000 Jewish children who, unlike $1,500,000$ others, survive).

11Montor, Report, 28 February, 5 April, 29 May, and 20 June 1946; Uل UA Campaigner (September, 1946); Philadelphia Inquirer, 30 March 1946; NYT, 9 August 1946; Solicitation of Christians for the United Jewish Appeal; A Memorandum of Survey and Recommendations, Kaplan Papers, S/53/373.

12Montor, Report, 22 March and 1 July 1946; UJA Campaigner (December, 1946). 1946.

13Montor, Report, 22 March, 15 April, 1 May and 22 May

14Montor, Report, 22 March 1946; Report to National Campaign Executive Committee of the UJA on the National Trade and Indust ry Division by Samuel Rothberg, 16 May 1946, Kaplan Papers, S/53/379. 
15Montor, Report, 12 March, 15 May, 20 June, and 24 October 1946; Report on National Women's Division to the... by Mrs. David Levy, 16 May 1946, Ibid.

16 The JDC, for example, had sent $\$ 38,000,00$ oveseas by August's end--more than during all of 1945--and desperately needed more funds.

17Montor, Report, 12 June, 1 July, 24 September 1946; UJA Campaigner (September, 1946); NYT, 25 August and 30 November 1946. The UJA consistently used pledges to announce its totals, but cash contributions rarely came close to pledges. In 1946 the UJA actually collected only $\$ 77,800,000$; Henry Montor, Letter to Eliezer Kaplan, 24 March 1947, Kaplan Papers, S/53/379.

18 "What are the Facts of the 1947 United Jewish Appeal," typescript, n.d., pp. 13-14; What are the Facts about the UJA? Material for Discussion at UJA National Conference, 29 November-3 December [1946], UJA Papers, Box. 3 .

19 Special Report, 16 october 1946. See also H. Montor, "The Jewish Prospect for 1947," Kaplan Papers, S/53/374. Mrs. Levy had already sounded this theme at Atlantic City, and it was captured on film ("Battle for Survival"): "has any one of us sacrificed anything that we really wanted in a material sense, for these our suffering, bleeding, starving, persecuted people?"

For Chicago's opposition to the 1947 campaign, and Montor's threat to establish a refugee camp on the outskirts of the city, see Henry Montor, oral Interview with Menahem Kaufman, 15 Apri1 1976.

\section{NOTES TO CHAPTER 4}

lupA, Program, National Conference, Atlantic City, 30 November-2 December 1946; UJA Campaigner (December, 1946); NYT, 23 February 1947, p. 1; Montor, Report, 6 December $1 \overline{946}$, especially pp. 8-40 which contain detailed expenditures (1946) and budgets (1947).

2 Henry Montor, Letter to Joseph Schlossberg, 20 November and 11 December 1946, Kaplan Papers, S/53/378; The Task Before Us: A Statement of Principles to Guide the Action of American Jewry in 1947, pp. 3-5, and what are the Facts? The Basis for the \$170 Million UJA in 1947, UJA Papers, Box 3 .

3 Martin Rosenbluth, Letter to Felix Rosenbluth, 12 February 1947, Kaplan Papers, S/53/335; UJA Campaigner (March, $1947)$.

4Montor, Report, 24 June 1947; UJA, A Report to Members of the National Christian Committee, 4 June 1947; NYT, 26 May 1947, p. 23 and 5 June 1947, p. 30; Montor, Report, 12 November 1947; NYT, 29 Apri1 1947, p. 2; Montor, Report, 21 April 1947; "We Must Not Forget: A Personal Message from Eddie Cantor" (UJA, 1947, 14 minutes), Rad Film Archives, Hebrew University (Mt. Scopus, Jersualem).

5Montor, Report, 12 March, 18 March, 14 April, 21 April, and 28 April 1947. Morgenthau repeated these successes in the fall at "Big Gift" affairs in Oklahoma City $(\$ 154,000$ in 1947 
vs. $\$ 81,000$ in 1946$)$, springfield, Mass. $(\$ 210,000$ vs. $\$ 133,000)$, Jacksonville $(\$ 208,000$ vs. $\$ 140,000)$ and Camden N.J. $(\$ 149,000$ vs. $(\$ 98,000)$. See also Montor, Report, 2 October 1947.

${ }^{6}$ Henry Morgenthau, Jr., Letter to Henry Montor, 1 May 1947, UJA Papers, Box 5.

7 Montor, Report, 2 June and 16 June 1947; Henry Morgenthau, Jr., Open Letter, 28 July 1947, UJA Papers, Box 5.

8Montor, Report, 4 Septenber and 2 October 1947.

${ }^{9} \mathrm{NYT}, 6$ September 1947, p. 19 and 10 October 1947, p. 10; Montor, Report, 8 september 1947.

10 See especially Henry Montor, Letter to Dr. George Stefansky, 24 July 1947; Kaplan Papers, S/53/329; Montor, The Jewish Prospect for 1947, p. 3, Ibid., S/53/374; and Notes on a Meeting...'14 October 1947 , Ibid., S/53/241.

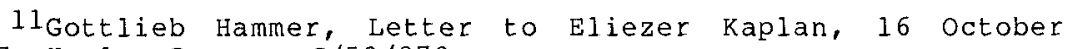
1947, Kaplan Papers, S/53/378.

12 Montor, Report, 5 January 1949; What is American Jewry's Responsibility in 1948 Through UJA A Workbook for Annual National Conference, Atlantic City, 12-15 December 1947, UJA Archives; Montor, Report, 22 December 1948.

13"Henry Morgenthau, Jr.," UJA Papers, Box 5, Montor, Report, 5 January 1948.

14 UJA oral History series, Golda Meir, 1975, Transcript at the Oral History Division of the Institute of Contemporary Jewry, Hebrew University, Jerusalem; Montor, Report, 2 February, 12 February, and 24 February 1948; UJA Campaigner (February, 1948).

15Montor, Report, 4 March and 26 March 1948. Immediately after the birth of the state of Israel in May, Golda returned to visit 24 communities during June and seek $\$ 100$ million in cash. By the end of July about $\$ 55$ million had been collected from this tour. See Montor, Report, 7 June, 28 June, and 29 July 1948.

16 palestine Post, 15 and 16 February 1948; Montor, Report, 2 February, 17 February, and 22 December 1948; UJA Campaigner (February, March, and April, 1948).

17 Henry Montor, Letter to Israel Goldstein, 10 September 1948, Kaplan Papers, S/53/378; Palestine Post, 2 October and 3 November 1948; E. Neumann, In the Arena, New York, 1976, p. 272.

18 palestine Post, 27 october, 3, 7, 10, 14 and 17 November 1948; Jerusalem Post, 3 January, 1950.

19 The leadership included Abraham Feinberg, chairman of the board of Kayser-Roth and associate chairman of the UJA of Greater New York: Harold Goldberg, Boston financier and Jewish communal leader; Fred Monoson, a Boston business executive, national chairman of the UJA rainwear division and a nationally known ZOA and JNF leader; and Joseph Shulman, a Paterson, New Jersey businessman and national chairman of UJA's textile division. 
20E. Stock, "The Reconstitution of the Jewish agency," AJYB $73(1972): 183$.

21 palestine Post, 7 December and 10 December $1948,4,10$, 12 , 13, and 14 Janúary 1949 , and $11,24,27$, and 28 February 1949, and 2 March 1949. For details of an earlier Silver-Montor confrontation (1944), and a bitter, often distorted, but different view of the controversy, see Neumann, In the Arena, pp. 193-194, 274-277.

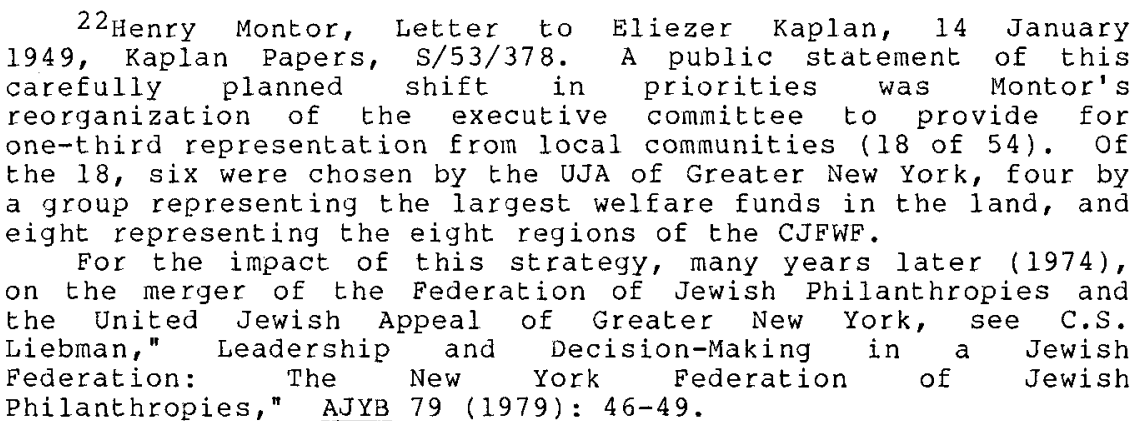

\section{NOTES TO CHAPTER 5}

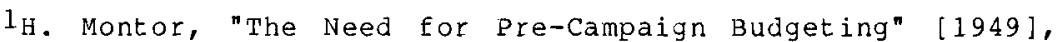
UJA Papers, Box 5. See also Irving Bernstein, oral Interview with Menahem Kaufman, 29 April 1980 (transcript, p. 25).

2 Montor, Report, 11 April 1949.

3 Big UJA News 1:1 ("Rush Bulletin on the Biggest Campaign in Jewish History"), n.d., UJA Archives (courtesy of Mr. Issachar Miron); Eliezer Kaplan, Letter to Henry Montor, 17 November 1949, Kaplan Papers, S/53/335. On Malben, see $H$. Agar, The Saving Remnant, pp. 231-36, and "Good Will Tour Master Speech," 3 October 1958, UJA Papers, Box 6 .

4 UJA Rress Release, from Meyer F. Steinglass, 6 April 1949 ("Nine Israeli. War Heroes Arriving Today"), courtesy of Mr. Miron. On the crisis of winter 1950/51, see NYT, 5 March 1950; Israel reports. . A Newsletter from the United Israel Appeal for Community Leaders (February, 1952), UIA Papers, Box 1; JTA, Daily News Bulletin, 20 september 1951.

5"Combined Jewish Appeal of Greater Boston--Proposed precampaign Budgeting Formulas-for 1950--Schedule B," Combined Jewish Philanthropies (=CJP) of Greater Boston Archives, courtesy of Dr. David Rosen.

${ }^{6}$ CJP Files: 1950.

${ }^{7}$ Ibid.

8Henry Montor, Letter to Eliezer Kaplan, 2 December 1950 , Kaplan Papers, S/53/378; Herbert Friedman, Oral Interview with Menahem Kaufman, Institute of Contemporary Jewry, Hebrew University, 1975-76. 
9 "Necrology," AJYB 76 (1976): 517; Who's who in American Jewry, Volume 3, 1938-39, New York, 1938, p. 951; Wesley H. Poling, Letter to Marc Lee Raphael, 24 March 1981. Schwartz's dissertation consisted of a translation and commentary to Abu Bakr Ibn Abid-Dunya Al-Qurashi's Qira D Daif (The Entertainment of Guests).

10 Herbert Friedman, Oral Interview with Menahem Kaufman. on "Operation Magic Carpet," see Look, 14 March 1950; 0 . Handiin, A Continuing Task, pp. 29-106; S. Barer, The Magic Carpet, London, 1952; and especially the migration of the family of Chaim Zalemah Zebeeb in Israel Reports. . . (March, 1950), UPA Papers, Box 2.

Montor claimed that he persuaded David Ben Gurion to select Schwartz as his, Montor's, successor; Henry Montor, Oral Interview wih Menahem Kaufman.

11J.J. Schwartz, "The 1951 United Jewish Appeal: A Report," UJA Papers, Box 1.

12 Herbert Friedman, oral Interview with Marc Lee Raphael, 9 July 1981; Herbert Friedman, oral Interview with Menahem Kaufman.

13Montor, Report, 29 February and 18 December 1952, 26 February, 20 April, and 12 May 1953; Look, 6 May 1952, pp. 89f.

14 Montor, Report, 26 February and 4 June 1954.

15 Montor, Report, 28 December 1954, 28 January, 8 March, and 9 June 1955; Herbert Friedman, Oral Interview with Howard Sachar, 25 August 1973, in the possession of Herbert Friedman; Herbert Friedman, oral Interview with Menahem Kaufman. Dr. Schwartz left the UJA to become vice-president of the Development Corporation for Israel, which directed the sale of Israel Bonds in America, as Levi Eshkol, according to Friedman, in a climactic meeting at the New York Waldorf-Astoria in December of 1954, ousted Montor from the Bonds position and installed schwartz.

\section{NOTES TO CHAPTER 6}

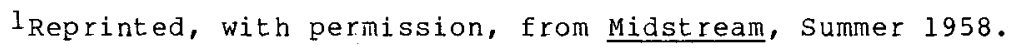

\section{NOTES TO CHAPTER 7}

Ion the exodus of Jews from North Africa during the 1950s, see especially D. Bension-Donath, Immigrants d'Afrique du Nord en Isräel, Paris, 1970, parts one and two; A. Chouraqui, Between East and West: A History of The Jews of North Africa, Philadelphia, 1968, pp. 263-315; J. Schechtman, On Wings of Eagles: The Plight, Exodus, and Homecoming of Oriental Jewry, New York, 1961; Israel, Ministry of Foreign Affairs, The Jewish Exodus from the Arab Countries and the Arab Refugees, Jerusalem, [1961?].

2P. Lendvai, Anti-Semitism without. Jews: Communist Eastern Europe, Garden City, New York, 1971, pp. 89-239, 326-49; Israel, Central Bureau of Statistics, Statistical Abstracts of Israel, Volumes 6-16 (1955-1965), passim.; "One Suitcase," a UJA film produced by Universal Studios; NYT, 9 
January 1957 (Polish Jews), 1 February 1959, 2 September 1962 (Algerian Jews); New York Post, 8-9 January 1957 (Egyptian Jews); Jerusalem Post, 14 March 1957 (Hungarian Jews); JTA Daily Bulletin, 29 December 1958; New York Herald Tribune (=NYHT), 18 and 22 February 1959 (Romanian Jews). Not a11 emigrants, of course, arrived safely; forty Moroccan Jews, denied exit permits, secretely boarded a Spanish vessel bound for Israel and drowned in the Mediterranean Sea; see NYHT, 12 January 1961.

3UJA Press Release, from Meyer steinglass ("UJA Opens Emergency Drive Today for $\$ 50,000,000$ in Cash. . .); Israel, Government Year-Book Jerusalem, 1958, pp. 356-57; Jerusalem Post, 20 January 1950. On the emerging development towns, see NYHT, 17 February 1959, and E. Spiegel, New Towns in Israel: Urban and Regional planning and Development, New York, 1967.

4Israel, Ministry of Housing, Israel Builds, 1948-1968, Tel Aviv, 1968, UJA, Report to Members of the National Campaign Council (=Report), I0 October 1960; G. Samuels, "Still They Come to Israel," NYT Magazine, 16 November 1958, pp. 24+ (especially on immigrant relocation in Nazareth, the Lachish region, and Beersheba); and on the ulpanim, see NYHT, 20 February 1959.

The huts which replaced the tents went through several stages, at least in UJA posters: at first they were made of tin, later of wood, still later of concrete blocks; and the huts were eventually replaced by prefabricated "houses" (first of wood, then of asbestos sheets) before the ma'abarot themselves began to disappear.

5UJA, Report, 26 september, 1959.

6 UJA, Report, 12 December 1964. For the executive vice-chairman's role in this advertising ("I did it all: design, execution, text."), see Herbert Friedman, oral Interview with Marc Lee Raphael.

7Herbert Friedman, Letter to Morton Berman, 5 September 1979, copy in possession of $H$. Friedman and reprinted, after slight editing, in M. M. Berman, For Zion's Sake: A Personal and Family Chronicle, Prescott, Arizona, 1980, pp. 346-49; Herbert Friedman, Oral Interview with Marc Lee Raphael, 9 July 1981. In 1970 Friedman became executive chairman and in 1972 executive vice-chairman, Israel; he resigned from executive office in 1972 and remained employed until May 1975 in order to complete twenty years of service. His secretive work for Aliyah Beth is discussed in detail in Herbert Friedman, oral Interview with Menahem Kaufman.

8Young Leadership Correspondence Files, YLD-5, 1960-62; Seymour J. Kaplan, Letter to Marc Lee Raphael (=MLR), 5 June 1981, Bernard Garber, Letter to MLR, 20 April 1981, Gordon F. Bloom, Letter to MLR, 13 April 1981, and George Shapiro, Lettler to MLR, 22 April 1981; Herbert Friedman, Oral Interview with Howard Sachar, 25 August 1973 and Herbert Friedman, Oral Interview with MLR, 9 July 1981. Because of its potential for subordinating local interests to overseas needs, most executive directors of federations responded to Friedman's plan with opposition. Many of them, in fact, continued to oppose the program after it began to recruit new manpower and to withhold from these new leaders local campaign positions. 
9Herbert Friedman, Oral Interview with Howard Sachar; Herbert Friedman, Oral Interview with MLR.

10UJA, Report, 3 March 1960; Herbert Friedman, oral Interview with Howard Sachar.

IlUJA, Report, 21 March 1958.

12UJA, Report[s], passim.; Fred Forman, chairman, national campaign cabinet, Letter to Label A. Katz of New Orleans, 18 september 1958, and "Good Will Tour Master Speech," 3 October 1958, in UJA Papers, Box 6. For a detailed discussion of "Good Will" Tours, see Herbert Friedman, oral Interview with MLR.

13UJA, Report, 11 February 1957, 21 March 1958, 13 March 1959, 19 Apri1 1961, 15 January 1962. In early 1957, the UJA brought Golda to America for a closed circuit telecast. Friedman recalled the event: "It was so incredible when her face came on that screen. It was like a revival meeting--fantastic; I think we got $\$ 10,000,000$ right there." Herbert Friedman, oral Interview with Menahem Kaufman.

I4UJA, Report, 10 December 1956; Herbert Friedman, Oral Interview with MLR; UJA, Report, 12 October 1964; Jerusalem Post, 17 October and 12 December 1968; Herbert Friedman, Oral Interview with Howard Sachar; United Jewish Fund \& Council [Columbus, Ohio], 1970 Campaign Advance Gifts Division Retreat Booklet, courtesy of Ben Mandelkorn. For a detailed diary of Friedman's North African trip, see H. A. Friedman, "A Mission to French North Africa," CCAR Journal il (October, 1955):3-8, 49 .

15UJA, Report, 12 October, 1964; Israel Education Fund, "Quarterly Review" 1:1 (February, 1966) and UJA, Report, 3 June 1966, in UJA Papers, Box 5; IEE, "Origin and Aims of the Israel Education Fund," February, 1972; IEF, "Statistical sumnary and Status Report," 15 May 1972, in UJA Papers, Box 6; Herbert Friedman, oral Interview with MLR.

16 Herbert Friedman, oral Interview with Menahem Kaufman and Herbert Friedman, Oral Interview with MLR. For Friedman's impact upon local federation directors I relied upon interviews with Darrell Friedman, 18 June 1981 and Ben Mandelkorn, 28 April 1977.

17UJA, A Report, 10:5 (9 September 1955) and $12: 3$ (17 June 1957). On Friedman's ability to "choreograph" cash conferences, see Herbert Friedman, oral Interview with MLR.

18UJA, A Report 16:4 (8 November 1961); United Jewish Fund \& Council [Columbus, Ohio], 1970 Campaign Workers's Manual, courtesy of Ben Mandelkorn.

19 Raphael Levy Files, PRD-1 and 2, 1960-63; Herbert Friedman, Oral Interview with MLR (where Friedman discusses the UJA-IRS situation at some length). For Warburg's position vis-a-vis the Middle East, see The Congressional Record, 11 February 1957, pp. 1886-7; J. P. Warburg, The Long Road Home: The Autobiography of a Maverick, New York, 1964, pp. 296-7; Warburg, Israel and the American Jewish Community, New York, $1959 ;$ D. Farrer, The Warburgs: The Story of a Family, New York, 1975, pp. 154-75. 
20 NYT, 8 February 1957 and 16 December 1963; Editorial, "The New Structure for American Jewish Fund Disbursement," Reconstructionist (15 April 1960): 3-6; Treasury Department, Internal Revenue Service, Internal Review Service Bulletin--Cumulative Bullet in (July-December 1963), pp. 101-5 (Section 170: Charitable, Etc., Contributions and Gifts). Sen. Ellender's remarks came in the larger context of the Senate's debate on the administration's Middle East proposal; see The Congressional Record, 11 February 1957, pp. 1834-91.

${ }^{21}$ Stock, "Reconstitution," pp. 185-6; Hearing Before the Committee on Foreign Relations. Eighty-Eighth Congress, First Session, Part 9, 23 May 1963.

22 Herbert Friedman, oral Interview with MLR.

\section{NOTES TO CHAPTER 8}

IFor a UJA delegation's eyewitness account of the humanitarian needs in Israel resulting from the Six Day war, see Jewish Telegraphic Agency, Daily News Bulletin, 21 June 1967.

2 United Jewish Fund, Minutes of the executive committee, 5 June 1967, Columbus Jewish Federation (=CJF).

3United Jewish Fund, Minutes of a special meeting of the board of trustees, 5 June 1967, CJF.

$4_{\text {A. Hertzberg, "Israel and American Jewry," Commentary }}$ 44 (August 1967): 69-73.

5Ohio Jewish Chronicle (=0JC), 1 June 1967; United Jewish Fund, Minutes of the executive committee, 5 June 1967.

$6_{\mathrm{OJC}}, 1,8,15$, and 22 June 1967; United Jewish Fund, Minutes of a joint meeting of the board of trustees of the UJF and the Columbus Jewish Welfare Federation, 29 June 1967, CJF.

7 Among the largest non-Jewish gifts the UJA announced were those of two textile executives, Robert T. Stevens $(\$ 250,000)$ and Roger Millikin $(\$ 300,000)$; see the NYT, 13 June 1967 .

$8_{\text {NYT, }} 8$ and 9 June 1967; Jewish post and Opinion, 9 June 1967 ; Columbus Jewish Federation, "Amounts pledged to 1967 regular and IEF campaigns and accounts receivable as of end of July, 1967," CJF.

Herbert Friedman claimed, one month after the Six Day War, that not only did the UJA have the "lowest administrative costs in the world" (5 percent), but that "the 1967 emergency campaign only cost an extra $\$ 560,000$, or a quarter of one percent of income;" see the Jerusalem Post, $17 \mathrm{July} 1968$.

For a lengthy discussion of Walter Annenberg's \$1,000,000 gift, see Herbert Friedman, oral Interview with Menahem Kaufman.

9 United Jewish Fund, Report on the Israel Emergency Fund, 14 September 1967, CJF; Ben Mandelkorn, Oral Interview wh Marc Lee Raphael, 28 April 1977. For a detailed account of national fundraising during the 167 War, see Herbert Friedman, oral Interview with MLR. 
10 OJC, 22 and 29 June 1967. Joseph J. Schwartz, formerly of the UJA but in 1967 at Israel Bonds, reported that $\$ 17,000,000$ in Bonds had been sold in late May/early June (NYT, 8 June 1967); by the end of the summer sales reached $\$ 100,000,000$ (NYI, 9 september 1967). 1975.

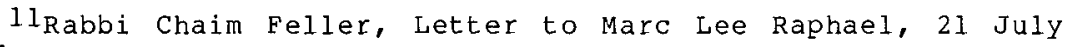

12JTA, Daily News Bulletin, 9 October 1973; Newsweek, 22 October 1973; Time, 29 October 1973.

13 Lexington Minute Man, 11 october 1973; Boston Jewish Advocate, 12 October 1973; Boston Hera1d-American, 10 October 1973; "Boston Responds to the Yom Kippur War," (16 mm.; 1973; CJP officel, courtesy of Michael Appel.

14 Boston Herald-American, 10 October 1973; Quincy Patriot Ledger, 10 October 1973; Medford Mercury, 10 October 1973; Chelsea Record, 10 october 1973; Lexington Minute Man, 18 October 1973; Newton Graphic, 18 october 1973; Boston Jewish Advocate, 25 october 1973. One UJA official estimated that a million Jews attended synagogue rallies on Monday evening.

15 Boston Globe, 18 October 1973; Boston Jewish Advocate, 8 November 1973 .

16 Ester Greenberg and Jay Solomon, Letter to CJP, 12 December 1973; Martha Livingston, Letter to CJP, 26 June 1974; Mitchell Marcus, Letter to Martha Livingston, 15 July 1974; Nancy Masters, Letter to CJP, 17 December 1973; Lauri Scher, Letter to CJP, n.d.; Judy sadow, Letter to CJP, 10 october 1973; Kenny Frieze, Letter to CJP, n.d., and David Frieze, Letter to CJP, n.d.; Fred Yankelevitz, Letter to CJP, 19 October 1973; Estelle Leontief, Letter to CJP, 13 october 1973--all in CJP Files, Third Floor, CJP. See also Herbert Bicherstoff, Letter to CJP, 26 October 1973, and Harry Thompson, Letter to CJP, 18 October 1973; CJP Files, Fourth Floor, CJP.

17Herbert Friedman, Oral Interview with MLR; Leonard
Fein, "Israel's Crisis: Its Effect on the American Jewish
Community and its Implications for Jewish Communal Service,"
Journal of Jewish Communal Service 45 (Fall 1968):14.

NOTES TO CHAPTER 9

$1_{\text {On }}$ the increased soviet Jewish emigration of the early 1970s, see A. Shub, "From Russia with Chutzpah: Origins of a New Exodus," Harper's Magazine (May 1972): 72-79.

2 The JDC facts and figures are from UJA World, 29 November 1971 and 4 December 1972, The American Jewish Joint Distribution Committee, Annual Reports, and UJA, The 1982 Campaign, p. 3 .

${ }^{3}$ I chatted with Mr. Bernstein briefly in Columbus, ohio at the home of Mr. Lexlie Wexner (23 November 1976), participated in two group discussions with him in New York at UJA headquarters (8-9 september 1977), and talked with him privately, in Jerusalem, at the home of Professor Moshe Davis (June 1980). 


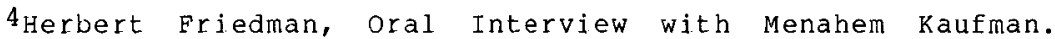
Friedman discusses the organizational structure of the UJA, during the 1950s and 1960s, at length in his oral interview with Marc Lee Raphael.

5 Notes on Meeting on Cash Collection Problems, 28 April 1972; Summary Minutes--Special Meeting of Problem Communities, 28 April 1972; Notes on Meeting on "Project Potential," 3 May 1972; Memo for 1972 "Project Potential" Campaign; Memorandum, Alvin H. Gilens to Bert Rabinowitz, 29 June 1972; UJA World, 1 March 1972 .

6 Memorandur, Leonard Bell to Paul zuckerman, Report on Operation Upgrade, 18 May 1972; Report to the National Executive Committee on Operation Upgrade Plans, 15 May 1972. For interesting details on Operation Upgrade, see Herbert Friedman, oral Interview with MLR.

$7_{\text {Report on Meeting of UJA Operation Israel }}$ Comnittee-Executive Committee Retreat--8-10 June 1972; Memorandum: Operation Israel 1973, 15 May 1972; Memorandum, Cameo Missions, 11 September 1972; Memorandum, 1973 Operation Israel Program, 11 September 1972; Report on Meeting of UJA Study Conference Committee--Executive Committee Retreat--8-10 June 1972 .

\section{UJA World, 1 March 1972.}

${ }^{9}$ Report on Meeting of UJA Committee on Solicitation--Executive Committee Retreat--8-10 June 1972; Memorandum, Evaluation of Speaker's Bureau Activity, 15 May 1972; Report to the National Executive committee on operation Breakthrough, 15 May 1972; "Aryeh Nesher, Solicitor General," Moment 2:8 (June 1977): 27-30, 60+. I witnessed this Israeli solicjtor extract $\$ 25,000$ from a physician who had gjven $\$ 10,000$ for several years.

lojames P. Rice, Executive director, Jewish Welfare Federation of Chicago, Letter to Raymond Epstein, president, JWF of Chicago, 18 June 1971; R. Epstein, Letter to Irving Bernstein, executive vice-chairman, UJA, 7 January 1972; I. Bernstein, Letter to $R$. Epstein, 17 January $1 ; 72$, in Executive Committee, UJA Papers, Box 6.

11 Memorandum, Confidential, to Members of the Executive Committee, Notes on Executive Committee Retreat [8-1] June 1972], 3 July 1972; Minutes Executive Committee, 22 september 1972 .

12 Ibid., Memorandum, Confidential, to UJA Executive Committee, Notes on UJA Executive Committee Meeting [20 November 1972], 30 November 1972; Notes on Meeting on Cash Collections problems, UJA National office, 28 April 1972. For a lengthy discussin of the role of national lay leaders in solicitations, see Herbert Friedman, oral Interview wth MLR.

13 Irving Bernstein, Oral Interview with Marc Lee Raphael, June 1980.

14 Memorandum, United Israel Appeal, Inc., Gottlieb Hammer to Members of the Executive Committee, 4 June 1972.

$15 \mathrm{~J} . \mathrm{K}$. Levine, "The Changing Role of Women in the Jewish Community," Response (Summer 1973): 59-65. 
16Minutes, Executive Committee retreat, 8-11 June 1972, in Executive Committee, UJA Papers, Box 6; A. Stone, "The Locked Cabinet," in Understanding American Jewish Philanthropy, edited by M. L. Raphael, New York, 1979, pp. 41-51; E. Solender, "Where are the Women?" Moment 2:8 (June 1977): 33-36, 63+; A. L. Lerner, "'Who Hast Not Made Me a Man: The Movement for Equal Rights for Women in American Jewry," American Jewish Jear Book 77 (1977): 31-34.

17I. Bernstein, The Future of Jewish Philanthropy. An Address at Brandeis University, 28 January 1980, p. 16.

\section{NOTE TO CHAPTER 10}

This entire chapter was helped by the undocumented course paper of Midge Merlin (Newton, Mass.).

lunited Jewish Appeal, E. D. Jaffe, "From Israel: Project Renewal: An Insider's View." A Project Renewal Briefing Paper; M. Gallanter, "Sorting Out Project Renewal: An Israel Experience," Record: The Magazine of the Women's Division of the United Jewish Appeal 36: l (Winter 1981): 9+.

2 These reservations were the subject of much discussion at the CJFWF Assembly I attended in Dallas during November of 1977, and were echoed by Robert Russell, Oral Interview with Marc Lee Raphael [MLR] 6 April 1978.

3UJA, E. D. Jaffe, "Division and Unity." A Project Renewal Briefing Paper; Eliezer D. Jaffe, Oral Interview with MLR, 14 JulY 1980.

4 Jerusalem Post International Edition $(=$ JPIE), 2 February and 3 March 1978; Jewish Post and Opinion (=JPO), 3 March, 10 March, and 4 April 1978. For a detailed discussion of the controversy over what is to be done about soviet Jews and their destination, see $I$. Greenberg, "Crossroads at Vienna: Olim and Noshrim," Reponse X:4 (Winter 1976-77): 11-23, and Irving Bernstein, Oral Interview with Menachem Kaufman, 29 April 1980 (transcript, pp. 42-46).

5 JPIE, 27 June 1978; JPO, 4 August and 15 September 1978.

6 JPO, 24 November 1978.

7 David Hersch, Oral Interview with MLR, 9 July 1981.

8 Hirsch Wise, Letter to MLR, 22 september 1981.

${ }^{9}$ S. Seigel, Confidential Report to Irving Bernstein, UJA executive vice-chairman and Robert Russell, Project Renewal Coordinating Committee chairman, 31 August 1979 (courtesy S. Seigel); JPO, 7 December 1979; Jerusalem Post, 16 May 1978; Saul Seige1, oral Interview with MLR, 12 October 1981.

10 JPIE, 2-8 December and 9-15 December 1979; JPO, 7 December 1979. This represented a turn-about for Yadin who had initially stated publicly (June 1978) that local slum residents could not be trusted to make the appropriate decisions.

ll Jerusalem post, 3 July 1980; JPIE, 29 June-5 July and 6-12 July 1980; Jewish Telegraphic Agency Bulletin, 7 July 
1980; Ma'ariv, 15 October 1978. M. Hazani's penetrating analysis ("Who Creates the slums?") of "the government's answer to the problem of housing: a gross, ugly, ill-kept tenement which creates a condition much worse than the one it was meant to alleviate" has been translated from Ma'ariv in the Jerusalem Institute for Federal Studies' Jerusalem Letter No. 15, 30 November 1978.

12 JPO, 21 November and 5 December 1980; JPIE, 21-27 December 1980 .

\section{JPIE, 21-27 December 1980 .}

14 David Hersch, oral Interview with MLR; M. Golden, "Project Renewal," p. 12, Columbus Jewish Federation.

15 Vincent Master to Project Renewal chairmen and Federation executive directors, "Explanations of Social, Educational and Cultural Programs," 24 December 1980; David Hersch, Oral Interview; UJA, R. Cerf, "Project Renewal in Action: Hatikvah Turns a Page."

16 JPIE, 2-8 September 1979; UJA Annual Report, May 1980, p. 12, and Annual Report, May 1981, p. 4; UJA 1982 Campaign Profile of Needs, 8 May 1981, p. 3; David Hersch, Oral Interview; JPIE, 27 september-3 october 1981.

17JPIE, 16-22 August and 23-29 August 1981; David Hersch, Oral Interview.

\section{NOTES TO CHAPTER 11}

$l_{M}$. Bloom, "The Missing $\$ 500,000,000, "$ Moment 6:2 (January-February 1981): 30-35; Moment 2:8 (June 1977): 31-32.

2 This figure greatly disappointed the UJA leadership because one year earlier twenty-three American Jews gave gifts of $\$ 500,000+$.

\section{UJA, Annual Report, 1981.}

4 Herbert Friedman, Oral Interview with Marc Lee Raphael, 9 July 1981; Irving Bernstein, Oral Interview with Marc Lee Raphae1, June 1980.

5M. L. Raphael, Understanding American Jewish Philanthropy, New York, 1979, pp. 7-25, 33-40, and 53-68.

6A. Stone, "Tzedakah Collectives: A New Approach to Jewish Giving," Jewish Digest 23 (November 1977): 7-9; S.M. Cohen, "Why Tzedakah Collectives?," Interchange 1:10 (June 1976): 2 .

7"Danny Siegel's 1980 Tz'dakah Report," Moment $6: 2$ (January-February 1981): 36-41.

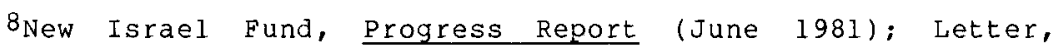
Janis Plotkin to Marc Lee Raphael, 26 October 1981.

${ }^{9}$ P. Ritterband and $S$. M. Cohen, "Will the Well Run Dry? The Future of Jewish Giving in America," Response 12:1 (Summer 1979): 9-17; Conversations with federation leaders, West Hartford, Conn., October 1981 . 
$10_{G}$. Rosenblatt, "The Youngers of zion," Moment $2: 8$ (June 1977): 37-40, 66+; J.S. Woocher, "The 1980 United Jewish Appeal Young Leadership Cabinet: A Profile," typescript; Letter, Irving Bernstein to Marc Lee Raphae1, 5 October 1981.

11 I corresponded with young leaders in Boston, Cincinnati, Columbus, Providence, and Seattle, and am grateful to Al Rosen, Avi Fox, Elliott Cohen, and Michael J. Aust in for their help.

12 Irving Bernstein, Oral Interview with Menahem Kaufman, 29 April 1980. 


\section{LIST OF TABLES}

\begin{tabular}{|c|c|}
\hline $4: 1$ & UJA Campaign Finances: \\
\hline $5: 1$ & UJA Campaign Finances: \\
\hline $7: 1$ & Jewish Immigration to Israel: 1948-1965 \\
\hline $7: 2$ & UJA Budgetary Requirements: 1961 \\
\hline $7: 3$ & UJA Campaign Finances: \\
\hline $8: 1$ & $\begin{array}{l}\text { Israel Emergency Fund Opening Gifts: } \\
1967\end{array}$ \\
\hline $8: 2$ & $\begin{array}{l}\text { Campaign Contributions of Two Columbus } \\
1961-1971\end{array}$ \\
\hline $9: 1$ & $\begin{array}{l}\text { UJA Executive Committee: } 1972 \text {, and Participants } \\
\text { in UJA Executive Committee Retreat: } 8-10 \text { June } \\
1972 \text {. }\end{array}$ \\
\hline $9: 2$ & Operation Upgrade: October 1971-April 1972 \\
\hline $9: 3$ & Operation Israel: 1972 \\
\hline $9: 4$ & $\begin{array}{l}\text { Cash Status and Accounts Receivable as of } 31 \text { May } \\
1972\end{array}$ \\
\hline $9: 5$ & UJA Campaign Finances: $1970-1980$ \\
\hline $10: 1$ & $\begin{array}{lrl}\text { Givat } & \text { Katznelson } \\
\text { Budget }: & 1981-1982\end{array}$ \\
\hline $1: 1$ & New Israel Fund Allocations: $1980-1981$ \\
\hline
\end{tabular}


4:1 UJA Campaign Finances: 1939-1948

$\begin{array}{ll} & \text { UJA Campaign } \\ \text { Goal } \\ \text { Year (millions) }\end{array}$

UJA Pre-Campaign Agreements

\section{$1939-45$}

1946

1947

1948
$\$ 103$

$\$ 170$

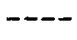

$\$ 250$ and JDC (578) million: negotiate.

\section{Pledges to UJA \\ (millions)}

After $\$ 2$ million to the NRS and JWB, UPA (438)

After a grant to refugee organizations, of first $\$ 75 \mathrm{milli}$ on: UPA (438) and JDC (57\%); of next

$\$ 25$ million: UPA (358)

and JDC (65\%); over $\$ 100$

After a grant to refugee organizations, of first $\$ 50$ million: UPA ( $45 \%$ ) and JDC (55\%); of next $\$ 75$

million: UPA $(558)$ and JDC (45\%); remainder to $\$ 250$ million: UPA (75\%) and JDC (25\%); over $\$ 250$ million: UPA (100\%)
$\$ 124$

$\$ 103$

Al1 Jewish Community Campaign Pledges

$$
\text { (millions) }
$$

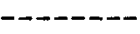

$\$ 132$

$\$ 157$

$\$ 125$

$\$ 157$

$\$ 150$

$\$ 200$

75
Percent of Pledges from All Campaigns to UJA

78

80 
5:1 UJA Campaign Finances: 1949-1955

\begin{tabular}{|c|c|c|c|c|c|}
\hline Year & $\begin{array}{l}\text { UJA Campaign } \\
\text { Goal } \\
\text { (millions) }\end{array}$ & $\begin{array}{l}\text { UJA Pre-Campaign } \\
\text { Agreements }\end{array}$ & $\begin{array}{l}\text { Pledges to } \\
\text { UJA } \\
\text { (millions) }\end{array}$ & $\begin{array}{c}\text { All Jewish Community } \\
\text { Campaign Pledges } \\
\text { (millions) }\end{array}$ & $\begin{array}{l}\text { Percent of } \\
\text { Pledges from } \\
\text { All Campaigns } \\
\text { to UJA }\end{array}$ \\
\hline 1949 & $\$ 250$ & $\begin{array}{l}\text { After a grant to refugee } \\
\text { organizations, of first } \\
\$ 50 \text { million: UPA (608) } \\
\text { and JDC (408); of next } \$ 25 \\
\text { million: UPA (708) and JDC } \\
(308) \text {; of remainder: UPA } \\
(758) \text { and JDC (258). }\end{array}$ & $\$ 103$ & $\$ 170$ & 63 \\
\hline 1950 & $\$ 272.455$ & $\begin{array}{l}\text { After.... of first } \$ 50 \mathrm{mil}- \\
\text { lion: UPA (60\%) and JDC } \\
(408) \text {; of next } \$ 25 \mathrm{mill} \text { ion: } \\
\text { UPA (708) and JDC (30\%); of } \\
\text { remainder: UPA }(75 \%) \text { and JDC } \\
(258) \text {. }\end{array}$ & C & $\$ 142$ & 66.5 \\
\hline 1951 & $\$ 203.685$ & $\begin{array}{l}\text { After.... of first } \$ 55 \mathrm{mil}- \\
\text { lion: UIA }(678) \text { and JDC } \\
(338) \text {; remainder: of UIA } \\
(87.58) \text { and JDC }(12.58) \text {. }\end{array}$ & $\$ 80$ & $\$ 136$ & 65 \\
\hline 1952 & $\$ 151.5$ & Same as 1951 & $\$ 70$ & $\$ 121$ & 60 \\
\hline 1953 & $\$ 144.5$ & Same as 1951 & $\$ 65$ & $\$ 115$ & 60 \\
\hline 1954 & $\$ 119.9$ & Same as 1951 & $\$ 60$ & $\$ 107$ & 58 \\
\hline 1955 & $\$ 99.5^{a}$ & Same as 1951 & $\$ 60$ & $\$ 110$ & 58 \\
\hline
\end{tabular}

a Expect $\$ 20$ million from West Germany 
7:1 Jewish Immigration to Israel: 1948-1965

$\begin{array}{llll}\text { Less than } 20,000 & 1953 & 1954 & \\ 20,000-40,000 & 1952 & 1955 & 1958 \\ 40,000-60,000 & 1956 & 1961 & 1964 \\ 60,000-80,000 & 1957 & 1962 & 1963 \\ 100,000-120,000 & 1948 & & \\ 160,000-180,000 & 1950 & 1951 & \\ 235,000-240,000 & 1949 & & \end{array}$


$\underline{\text { AGENCY }}$

Jewish Agency For Israel, Inc. New York
B U D G E T A R Y I T E M

Agricultural settlements.

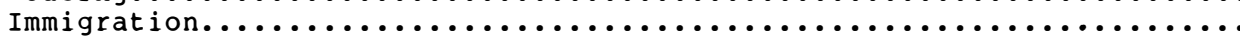

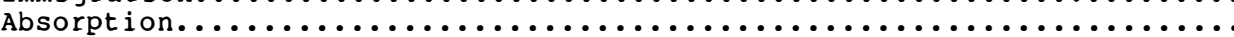

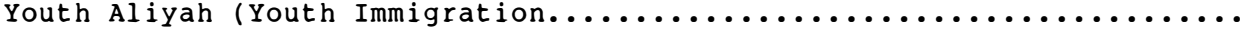

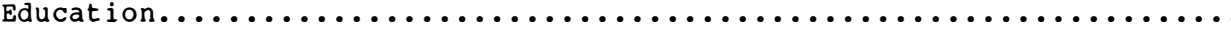

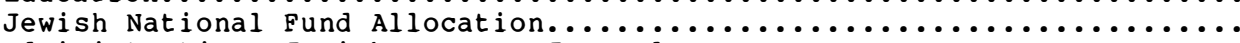

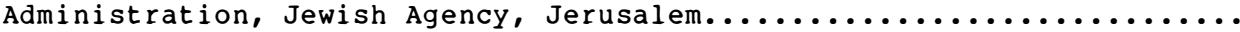

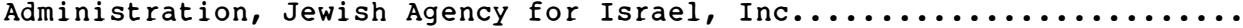
Debt Service

Amount to be provided by UJA

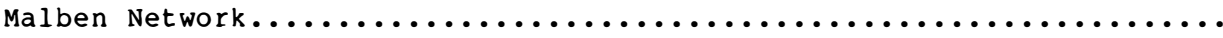

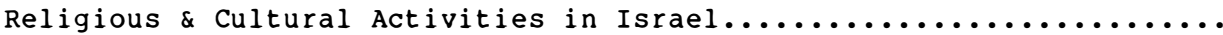

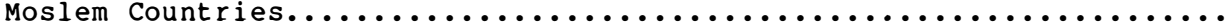

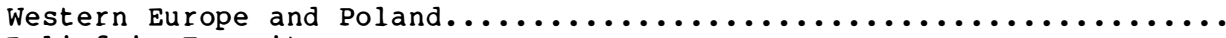

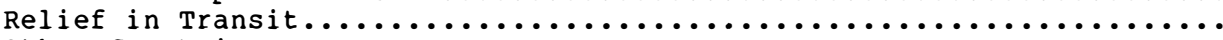

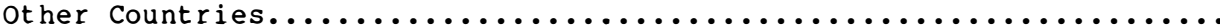

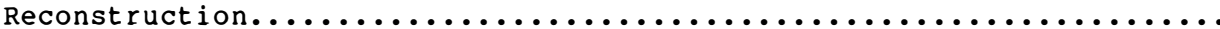

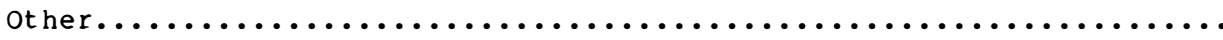

Anticipated Income from Sources other than UJA: Amount to be provided by UJA.
A M O U N T

$\$ 25,617,000$

$7,747,000$

$3,706,000$

$4,344,000$

$1,247,000$

$1,352,000$

622,000

$1,205,000$

255,000

$5,000,000$ $\$ 51,095,000$ $\$ 51,095,000$

$\$ 10,000,000$ 785,000

$5,100,000$

$4,900,000$

$4,000,000$

290,000

$1,800,000$

$1,900,000$

$\$ 28,775,000$ $\$ 11,575,000$ $\$ 17,200,000$ 


\section{7:2 UJA Budgetary Requirements: 1961 (continued)}

\section{AGENCY}

New York

Association for

New Americans

United Hias

Service

United Jewish

Appeal, National

B U D G G E I T A R $R$ Y I I T E M

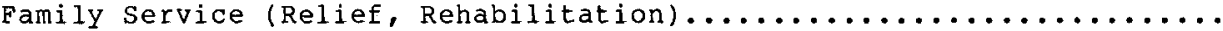

Vocational Service (Placement, Training, Guidance, Loans)...........

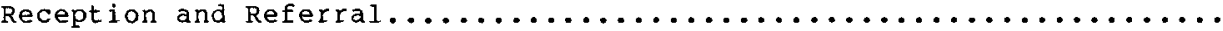

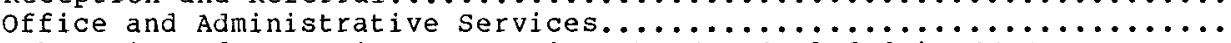
Subventions for Services to Immigrants Not Included in NYANA.........

Amount to be provided by UJA.............

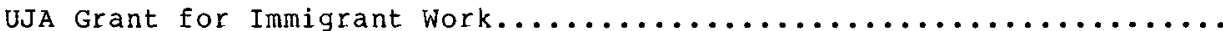

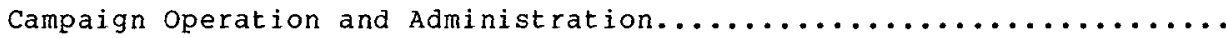

Total 1961 United Jewish Appeal Requirements

\section{$\underline{A} \mathrm{MOUNT}$ \\ $\$ 344,450$ \\ 138,550 \\ 30,100 \\ 42,000 144,900 \\ $\$ 700,000$ \\ $\$ 245,000$}

$\$ 3,500,000$

$\$ 72,740,000$ 


\section{7:3 UJA Campaign Finances: 1956-1969 (in millions)}

$\begin{array}{cc}\text { Year } & \text { National } \\ \text { Inaugural } \\ \text { Conferences }\end{array}$

1956

1957

1958

1959

1960

1961

1962

1963

1964

1965

1966

1967

1968

1969
Campaign Goals

Regular Fund Special/Emergency Rescue Funda

105.3
105.6
102.0
105.1
No quota
$72.7 \mathrm{~b}$
60.0
60.0
69.0
71.0
73.4
75.6
----
365.0

All Jewish Community Campaign pledges
Campaign Achievement: Cash Collected for UJA

ame Special or Emergency campaign sought to completely reverse the ration of sums generally allocated for domestic and overseas needs by allowing donors, after a "regular" gift, to give loo percent of their donation to overseas needs.

bHerbert Friedman finally succeeded in 1961 in having the "goal" realistically match the expectations. 
8:1 Israel Emergency Fund Opening Gifts: 5-11 June 1967

$\begin{array}{ll}\text { New York } & \text { The first } 74 \text { gifts to the IEF totalled } \$ 9,702,000 a \\ \text { Cleveland } & \text { The first } 150 \text { gifts to the IEF totalled } \$ 3,000,000 \\ \text { Boston } & \text { The first } 51 \text { gifts to the IEF totalled } \$ 2,500,000 \\ \text { Baltimore } & \text { The first } 75 \text { gifts to the IEF totalled } \$ 1,834,000 \\ \text { Dallas } & \text { The first } 300 \text { gifts to the IEF totalled } \$ 1,560,000 \\ \text { Milwaukee } & \text { The first } 70 \text { gifts to the IEF totalled } \$ 1,042,000 \\ \text { Los Angeles } & \text { The first } 6 \text { gifts to the IEF totalled } \$ 925,000 \mathrm{~b} \\ \text { San Francisco } & \text { The first } 26 \text { gifts to the IEF totalled } \$ 786,000 \\ \text { Tulsa } & \text { The first } 19 \text { gifts to the IEF totalled } \$ 540,000 \\ \text { Hartford } & \text { The first } 4 \text { gifts to the IEF totalled } \$ 425,000\end{array}$

a These same individuals gave $\$ 2,091,000$ to the 1967 regular campaign.

b This included $\$ 500,000$ from a previous non-contributor. 
8:2 Campaign Contributions of Two Columbus Jews: 1961-1971

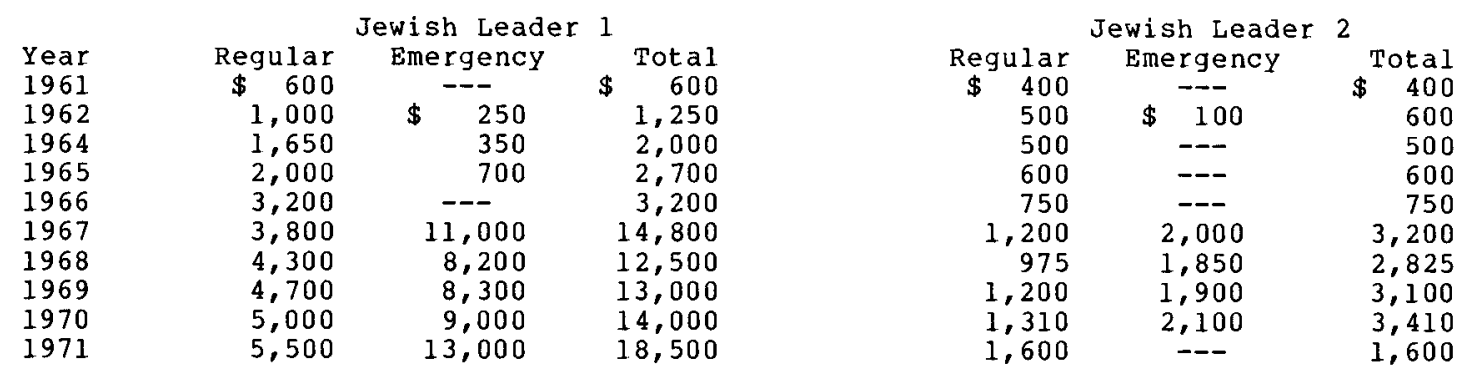


9:1 UJA Executive Committee: 1972, and Participants in

UJA Executive Committee Retreat: 8-10 June 1972

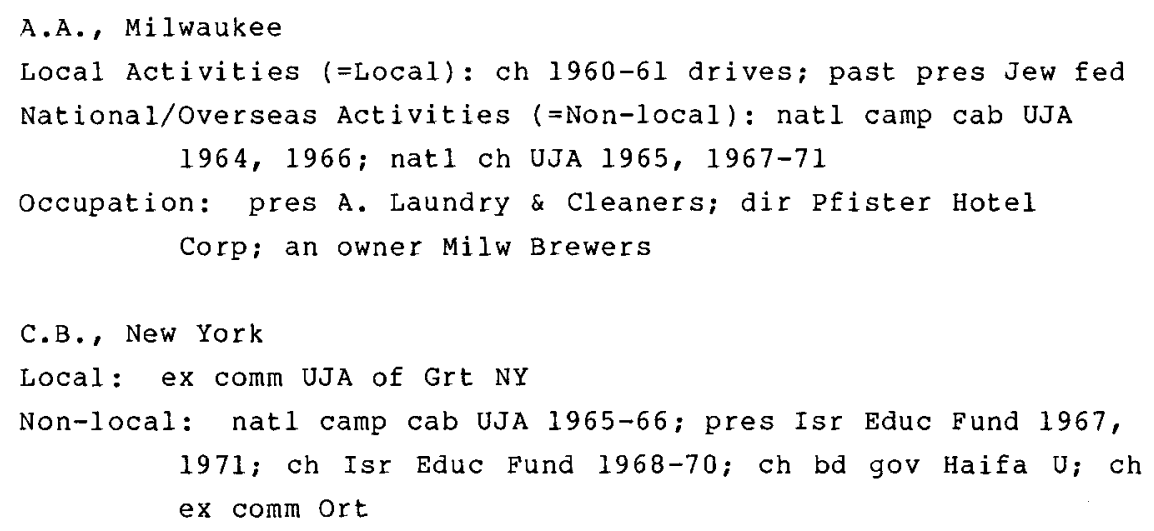




\section{9:1 UJA Executive Comm. . ( $\left.\operatorname{con}^{\prime} t\right)$}

A. G. Harrisburg

Local: genl camp ch UJA/Isr Bonds 1967; dir Planned Parenthood Non-local: ex comm UJA 1970; natl camp cab UJA 1971

occupation: ch bd, chief officer Rite Aid Corp; dir Penn Pacific Corp

\section{E. G. Clevel and}

Local: trustee Jew Comm Fed since 1957

Non-1ocal: nat 1 ch UJA 1963-66; assoc genl ch UJA 1967; gen1

ch UJA 1968-71; pres UJA 1972; bd trustees JDC; v-p United HIAS

Occupation: partner in law firm; exec v-p U.S. Realty Inves

H. G., New Orleans

Local: asst dist atty 1950-53; asst city atty 1954-65; pres JWF Non-local: natl ch UJA Y L cab 1968; ex comm UJA 1969-71; nat l council JDC; ex bd, trustee ADL

occupation: partner in law firm

L. G., Dayton

Local: ex comm Jew Comm Council; camp ch Isr Emerg Fund

Non-local: ex comm UJA 1968-69; natl ch UJA 1970-71; ch UJA Oper Is $r$

Occupation: partner in law firm; pres Goldman's Inc, Dixie Enterprises, $R \& R$ Distrib Co.

G. H., New York

Non-local: v-p Amer Comm for Weizmann Inst; natl sec UJA $1963-66,1968-69,1971$

Occupation: ex $\mathrm{v}$-ch UIA; pres Amer-Isr Shipping Co, Transport Commercial Corp; ch, NY Adv Bd Bank L'eumi L'Israel

M. H., Providence

Local: genl ch JWF drives 1960-62

Non-local: natl camp cab UJA 1964, 1966-67; nat ch UJA 1968-69; hon natl ch UJA 1970-71

occupation: pres Hasbro Industries, toy and school supply industry 


\section{9:1 UJA Executive Comm. . . ( $\left.\operatorname{con}^{\prime} t\right)$}

S. H., New York

Non-local: natl sec UJA 1968-69, 1971; dir JDC programs in Germ, Morocco, Pol, Geneva, Bombay

Occupation: ex $\mathrm{v}-\mathrm{ch}$ JDC

M. L., New York

Local: pres UJA of Grt NY 1969; trustee FJP

Non-local: ex comm UJA 1968; co-treas UJA 1969; trustee UIA;

natl ch UJA $1970-71$

J. M., New York

Local: bd dir, ex comm, camp committee UJA of Grt NY

Non-local: ch Spec Fund UJA 1956, 1959-60; co-ch Emerg Resc

Fund UJA 1957; ch Resc Fund UJA 1958; hon Spec Fund $\mathrm{ch}$

UJA 1962-71; bd dir UIA; depty ch bd gov Hebrew 0

occupation: ch bd dir Hudson Paper and Pulp co

J. M., Baltimore

Non-local: natl camp cab UJA 1951-55; ch natl camp cab UJA 1956-57; natl ch UJA 1958-60; genl ch 1961-64; hon $\mathrm{ch}$ UJA 1965-66, 1968-69; ch Isr Educ Fund 1967; hon gen ch UJA 1970-71; pres Palest Econ Corp; bd gov Isr. Bonds occupation: home bldr and shopping center developer

E. M., New York

Non-local: ex staff UJA since 1958; ex comm JJA 1971

occupation: ex $v-p$ and camp dir UJA of Grt NY

B. R., Boston

Local: genl camp ch CJP 1968-70; ex comm CJP; bd dir Beth Isr Hosp

Non-1ocal: ex comm UJA 1969-71; ex comm UIA

Occupation: pres Colonial Provis Co; dir Amer Meat Inst

M. R., Washington, D.C.

Local: past pres UJA of Grt Wash

Non-1ocal: natl camp cab UJA 1967-70; ex comm UJA 1971

occupation: former pharmacist and radio station pres 


\section{$9: 1$ UJA Executive Comm... (con't)}

M. R., New York

Local: genl ch UJA of Grt NY; dir Outward Bound; $v$-ch of Founders Albert Einstein Coll of Med

Non-local: ex comm Jew Theol Sem; bd overseas Weizmann Inst Occupation: pres and ch bd Rapid-American Corp; v-ch McCrory Corp; ch bd Glen Alden Corp.

M. R., Roanoke

Local: ch UJA drive

Non-local: ch Fund Raising Comm of $Y$ L cab; natl camp cab UJA Occuation: pres Oak Hall Cap and Gown Co

R. R., Miami

Local: v-p and dir J Fed 1971-72; pres J Fed 1972-73

Non-local: ex comm UJA 1970-71; bd gov Jew Agency 1971-73; bd gov Tel Aviv U

Occupation: pres and ch bd R. Aluminum Corp; dir Pan Amer Bank of Hialeah

S. R., Peoria

Local: past pres J. Comm Council

Non-local: ex comm UJA 1946, 1948, 1970-71; initial gifts ch UJA 1948-49; natl camp cab UJA 1949, 1951-52, 1954-60, 1964-69; founder and natl camp ch Isr Bonds

Occupation: dir Amer Distilling Co and Parwin Dormeyer Co; pres Isr Investment Corp

W. R., New York

Local: ch Ist Emerg Fund 1968-71

Non-local: nat $1 \mathrm{ch}$ UJA 1942-52, 1963; natl camp ch UJA 1953-54; genl ch UJA 1955-57; hon ch UJA 1964-69; hon genl ch UJA 1970-71; natl ch JDC 1958-62; v-p United HIAS

Occupation: ch bd American Securities Corp.

A. S., Newark

Local: camp cab and ex comm J Comm Council; genl ch JCC 1961-62; pres Beth Isr Hosp

Non-local: first ch Y L cab 1963; natl camp cab UJA 1964-67; ex comm UJA 1968-71

occupation: partner Levin-Sagner Companies, builders 
9:1 UJA Executive Comm. . . (con't)

A. S., Davenport IO

Local: pres JWF; ch UJA

Non-local: ex comm UJA 1969-71

occupation: ch bd and pres Alby Metal Products, Inc and Exovac reactive Alloys Corp

E. S., Los Angeles

Local: genl ch UJWF-IEF 1970; co-genl ch 1971

Non-local: nat 1 camp cab UJA 1971

occupation: attorney

L. S., Norfolk

Local: ex comm J Comm Council; ch UJF camp 1964; dir De Paul Hosp

Non-local: natl camp cab UJA 1966-67; ex comm 1968; natl ch $1970-72$

Occupation: pres Haynes Furn Co

M. S., San Francisco

Local: past pres JWF; past genl ch Isr Bonds; past

Commissioner of San Fran Hous Authority

Non-local: ex comm UJA 1971; nat1 v-p Amer Jew Comm

occupation: dir Fairmount Hotel; dir South seas Mining Co, Ltd

P. S., Philadelphia

Local: ch adv gifts Allied Jew Appeal 1967; genl ch AJA 1968

Non-local: natl camp cab UJA 1968-70; ex comm UJA 1971

occupation: built Fort Wash, PA Industrial Park and office

Center

R. S., Chicago

Local: past pres and genl ch, Chic J Appeal; dir JWF

Non-local: v-ch Roos Univ

Occupation: pres Assoc Agencies, Inc since 1966

L. T., New York

Local: genl ch UJA of Grt NY; trustee FJP and NYU

Non-local: ex comm UJA 1971

occupation: ch bd and ch exec officer Loew's Theaters, Inc; dir Mad Sq Garden, Sun Chem Corp, The Manhattan Fund 


\section{$9: 1$ UJA Executive Comm. . ( $\left(\operatorname{con}^{\prime} t\right)$}

P. Z., Camden

Local: genl ch Allied J Appeal 1948-49, 1959; gen ch Isr Bonds $1954-57$

Non-local: natl camp cab UJA 1959-60; natl ch UJA 1964-71;

pres Isr Educ Fund 1972; headed natl cash camp UJA three times

Occupation: ch bd Assoc-East Mortg Co and Assoc Mortg

Companies, Inc; pres First Penn Mortg Trust

P. Z., Detroit

Local: past pres United J Char; headed U.S. Food for Peace Committee (Mich)

Non-local: natl camp cab UJA 1964-67; natl ch UJA 1968-71;

genl ch UJA 1972

Occupation: ch Velvet-O'Donnell Corp (peanut importers and distribs) 
9:2 Operation Upgrade: October 1971 - April 1972

\begin{tabular}{|c|c|c|c|c|c|}
\hline Category & \# of Gifts & .71 Value & 172 Value & $\$$ Increase & Increase \\
\hline $0-\$ 999$ & 223 & 76,735 & 229,010 & $\$ 152,275$ & 198 \\
\hline $1,000-1,999$ & 214 & 219,150 & 351,790 & 132,640 & 61 \\
\hline $2,000-2,999$ & 138 & 264,493 & 407,243 & 142,750 & 54 \\
\hline $3,000-3,999$ & 103 & 294,924 & 391,400 & 96,476 & 33 \\
\hline $4,000-4,999$ & 48 & 190,250 & 250,000 & 59,750 & 31 \\
\hline $5,000-5,999$ & 52 & 233,250 & 340,100 & 106,850 & 46 \\
\hline $6,000-6,999$ & 23 & 136,840 & 166,300 & 29,460 & 22 \\
\hline $7,000-7,999$ & 31 & 205,800 & 246,000 & 40,200 & 20 \\
\hline $8,000-8,999$ & 6 & 49,200 & 65,500 & 16,300 & 33 \\
\hline $9,000-9,999$ & $\frac{2}{840}$ & $\$ \frac{18,000}{\$ 1,688,642}$ & $\frac{20,000}{\$ 2,467,343}$ & $\frac{2,000}{\$ 778,701}$ & $\frac{11}{478}$ \\
\hline
\end{tabular}


9:3 Operation Israel: 1972

B. RETURNS (New money only, from non-professional participants).

\begin{tabular}{|c|c|c|c|c|c|}
\hline Flight Type & $\#$ Gifts & Prev. Yr. Values & pledged & Total Gain & Pct. Gain \\
\hline 1-M.D. COUPLES & 61 & 83,645 & 139,650 & 56,005 & 67.1 \\
\hline 2-COUPLES & 177 & 725,340 & 929,760 & 204,420 & 28.2 \\
\hline 3-MEN & 78 & 184,485 & 296,200 & 111,715 & 60.6 \\
\hline 6-COUPLES & 161 & 833,063 & $1,234,061$ & 400,998 & 48.1 \\
\hline 7-MEN & 63 & 139,780 & 229,810 & 90,030 & 59.0 \\
\hline 8-WOMEN'S DIV. & 82 & 36,094 & 70,325 & 34,231 & 94.8 \\
\hline 9-COUPLES & 78 & 220,863 & 326,567 & 105,704 & 47.9 \\
\hline 10-MEN & 42 & 51,085 & 83,950 & 32,865 & 65.3 \\
\hline 11-COUPLES & 40 & 95,350 & 192,850 & 97,500 & 102.3 \\
\hline TOTALS & $782 *$ & $\$ 2,369,705$ & $\$ 3,503,173$ & $\$ 1,133,468$ & 47.8 \\
\hline TOTALS & 1,027 & $2,843,395$ & $4,734,178$ & $1,890,783$ & 66.5 \\
\hline
\end{tabular}

*1,390 participants 
I. 1967 EMERGENCY FUND

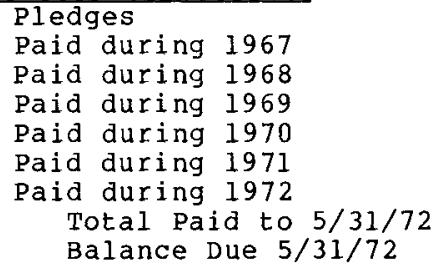

Paid during 1967

Paid during 1968

Paid during 1969

Paid during 1970

Paid during 1971

Paid during 1972

Total paid to 5/31/72

Balance Due $5 / 31 / 72$

II. 1968 EMERGENCY FUND
Pledges
Paid during 1968
Paid during 1969
Paid during 1970
Paid during 1971
Paid during 1972
Total Paid to 5/21/72
Balance Due 5/31/72

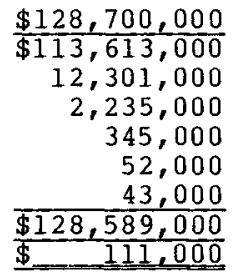

$\$ 60,000,000$ $33,935,000$ $20,698,000$

$2,373,000$ 320,000 216,000

$\$ 57,542,000$

$2,458,000$

III. 1969 EMERGENCY FUND

\section{pledges}

Paid during 1969

Paid during 1970

Paid during 1971

Paid during 1972

Total Paid to $5 / 31 / 72$

Balance Due $5 / 31 / 72$
$\$ 75,000,000$

$\$ 40,955,000$

$24,743,000$

$3,472,000$

964,000

$\frac{\$ 70,134,000}{\$ 4,866,000}$
$\$ 44,300,000$

$\$ 38,170,000$

$5,190,000$

701,000

119,000

55,000

45,000

$\$ 44,280,000$

20,000

$\$ 16,000,000$

$11,257,000$

$2,815,000$

762,000

208,000

101,000

$\$ 15,143,000$

857,000

$\$ 18,000,000$

$\$ 13,387,000$

$2,431,000$

486,000

238,000

$\$ 16,542,000$
$\$ 173,000,000$ $\$ 151,783,000$ $17,491,000$

$2,936,000$

464,000

107,000 8,000

$\$ 172,869,000$

$\$=131,000$

$\$ 76,000,000$ $45,192,000$ $23,513,000$

$3,135,000$ 528,000 317,000 $\$ 72,685,000$ $3,315,000$

$\$ 93,000,000$ $\$ 54,342,000$ $27,174,000$ $3,958,000$

$1,202,000$ $\$ 86,676,000$ \$ $6,324,000$ 
9:4 Cash Status.. (continued)

NATIONAL

$\begin{array}{r}\$ 93,500,000 \\ \$ 52,090,000 \\ 29,394,000 \\ 4,939,000 \\ \$ 86,423,000 \\ \hline \$, 077,000 \\ \hline\end{array}$

V. 1971 EMERGENCY FUND

$$
\text { Pledges }
$$

Paid during 1971

Paid during 1972

Total Paid to $5 / 31 / 72$

Balance Due $5 / 31 / 72$

VI. $\frac{1972 \text { EMERGENCY FUND }}{\text { Paid during } 1972}$

VII. RECAP OF CASH RECEIVED IN 1972

$\begin{array}{llll}\text { 1. } & 1967 & \text { Emergency Fund } \\ \text { 2. } & 1968 & \text { Emergency Fund } \\ \text { 3. } & 1969 & \text { Emergency Fund } \\ \text { 4. } & 1970 & \text { Emergency Fund } \\ \text { 5. } & 1971 & \text { Emergency Fund } \\ \text { 6. } & 1972 & \text { Emergency } & \text { Fund } \\ \text { 7. } & 1970 \text { and Prior Regular } \\ \text { 8. } & 1971 \text { Regular } \\ \text { 9. } & 1972 \text { Regular }\end{array}$

$12,149,000$
NEW YORK CITY

TOTAL

$\$ 21,500,000$

$\$ 14,814,000$

$3,316,000$

258,000

$\$ 18,388,000$

$\$ 3,122,000$

$\$ 24,000,000$

$\$ 18,005,000$

$2,300,000$

$\$ 20,305,000$

$\$ 3,695,000$

$\$ 5,578,000$

$\$ \quad 45,000$

101,000

238,000

258,000

$2,300,000$

$5,578,000$

486,000

$4,235,000$

$5,188,000$

$18,429,000$

$\$$
$\$ 115,000,000$

$\$ 66,904,000$

$32,710,000$

$5,197,000$

$\$ 104,811,000$

$\$ 10,189,000$

$\$ 156,000,000$

$\$ 90,152,000$

$20,799,000$

$\$ 110,951,000$

$\$ 45,049,000$

$\$ 21,351,000$

88,000 317,000

$1,202,000$

$5,197,000$ $20,799,000$

$21,351,000$

$3,343,000$

$10,393,000$

$17,337,000$

$\$ 61,598,000$ 
$9: 4$ Cash status . - (continued)

NATIONAL NEW YORK CITY TOTAL

VIII. ACCOUNTS RECEIVABLE RECAP
1. 1967 Emergency Fund
2. 1968 Emergency Fund
3. 1969 Emergency Fund
4. 1970 Emergency Fund
5. 1971 Emergency Fund
6. 1970 and Prior Regular
7. 1971 Regular
$\$ 111,000$
$2,458,000$
$4,866,000$
$7,077,000$
$41,354,000$
$6,311,000$
$9,320,000$
$\$ 71,497,000$
$\$ 20,000$ 857,000
$1,458,000$
$3,112,000$
$3,695,000$
$2,042,000$
$5,113,000$
$\$ 16,297,000$

$\$ \quad 131,000$ $3,315,000$ $6,324,000$

$10,189,000$

$45,049,000$

$45,049,000$
$8,353,000$

$14,433,000$

$87,794,000$ 


$\begin{array}{cccc}\text { Year } & \begin{array}{c}\text { UJA Campaign Finances: } \\ \text { All Jewish Commity } \\ \text { Campaign Pledges }\end{array} & \text { UJA Allocation } & \begin{array}{c}\text { Percent of Pledges } \\ \text { From All Campaigns } \\ \text { to UJA }\end{array} \\ & & & \\ 1970 & \$ 299.0 & \$ 195.0 & 658 \\ 1971 & 360.0 & 239.0 & 66 \\ 1972 & 370.0 & 246.0 & 66 \\ 1973 & 365.2 & 252.0 & 75 \\ 1974 & 669.8 & 504.7 & 63 \\ 1975 & 471.9 & 298.8 & 61 \\ 1976 & 451.1 & 275.9 & 60 \\ 1977 & 455.8 & 272.8 & 57 \\ 1978 & 473.9 & 271.4 & 56 \\ 1979 & 481.0 & 270.7 & 57 \\ 1980 & 508.7 & 288.8 & \end{array}$

As of November 1981, From David Agronin, National Allocations Director, UJA. 
10:1 Givat Katznelson (Nahariya) Project Renewal Budget: 1981-1982

IS

$\Phi$

Totals:

$8,708,270$

$\underline{725}, 685$

General Information Activities

Neighborhood newspaper

30,000

$\underline{2,500}$

Early Childhood Enrichment Program

Equipment

$\frac{85,000}{20,000}$

7,083

65,000

5,417

Subsidized Day Care Centers - Subsidy to families on welfare

158,400

13,200

Youth Club

Equipment

Activities

Joint expenses

510,550

100,000

348,900

61,650

42,545

8,333

29,075

5,137

Sports Program

Equipment

93,547

$\frac{7,795}{4,167}$

31,680

11,867

2,640

988

Joint expenses

462,158

217,920

39,238

38,513

$\frac{38,513}{18,160}$

3,270

205,000

17,083

Personnel

250,000

$\underline{20,833}$

289,650

250,000

39,650

24,137

20,833

3,304

Joint expenses

Day Center for the Elderly

Renovations and enlargement

Equipment and furniture

$\frac{826,800}{8,000}$

$\frac{68,900}{667}$

50,000

280,000

56,000

Maintenance

Special activities

97,200

Personnel

335,600

4,167

23,333

4,667

8,100

27,966

Protected Housing for the Elderly Renovations

$\underline{3,000,000} \quad \underline{250,000}$

Enlargement of Apartments for the Elderly - Amigur apartments

$\underline{2,200,000} \quad \underline{183,333}$

Tehila, Basic Adult Education

$$
\text { Program - Stipends }
$$

$\underline{435,000}$

36,250

Summer Activites - Participation

in summer camps

$\underline{74}, 150$

$\underline{6,179}$

Participations Budget - stipends

for Higher Education

$\underline{203,015} \quad \underline{16,918}$ 
10:1 Givat Katznelson (Nahariya)

Project Renewal Budget: 1981-1982

Special Cultural Activities Budget

Administration and Organization Accounting
IS

20,000

$\Phi$

$\underline{1,666}$

$\underline{70,000}$

$\underline{5,833}$ 
11:1. New Israel Fund Allocations: 1980-1981

Innovative Services 23.5 percent

Arbitration Center

Lifeguard on the Road

NOLAD: Vocational School Volunteer Project

Ohel Shmuel: Neighborhood Volunteers

Pregnancy Counseling Service

Women's Rights 23 percent

Battered Women's Shelter

Rape crisis Center

Arab-Jewish Relations 10.5 percent

Negev Civil Rights Association

Neve Shalom: Model Community

SHUTAFUT: Partnership

Civil Rights 28.5 percent

Association for Civil Rights in Israel

ELI: Association for the Protection of the child

ENOSH: Association for the Advancement of the Mentally Disadvantaged

Next of Kin Widows

ZAHAVI: The Association of Large Families

Community Action 14.5 percent

Aliya and Klita Task Force

OHALIM: The Organization for Neighborhood Progress

OHEL YOSSEF: Rehabilitation Project 


\section{NDEX}

Admoni, Yehiel 108

Agronin, David $9: 5$

Akron 67

Algeria $64,73,85$

Aliyah Beth $66,127 \mathrm{n}$

Allied Jewish Campaign (1930) 3-4

Allocations: local vs overseas $72-73,96-97$

Allon, Yigal 94

American Financial and Development Corporation for Israel 39, $126 n$

Annenberg, Walter 129 n

Argentina 86

At lanta $27,30,9: 1$

Atlantic City 21, 27, 29, 36, 67

Austria $29,66,71$

Baltimore $34,45,106,9: 1$

Baruch, Bernard 22

Begin, Menahem 101, 105

Ben Gurion, David $35-36,68,126 \mathrm{n}$

Benny, Jack 69

Bernstein, Irving 47, 86-88, 92, 99, 111, 115, 130n

Bicherstoff, Hebert 83

Big gift/big giver 18, 21-23, 30, 33-34, 42, 44-45, 47-61, 68, $70,74,91-92,94,98,111-112,118 \mathrm{n}, 123 \mathrm{n}-124 \mathrm{n}$

Birmingham 104

Bloom, Melvyn 111

Bonds for Israel $33,39,43,46,80,126 \mathrm{n}, 130 \mathrm{n}$

Boston $4,22,25,26,41-43,45,67,70,81-83,9: 1$

Bressler, David 4

Brookline 82

Brown, David 3, 117n

Buffalo $24,41,79$

Bulgaria 39

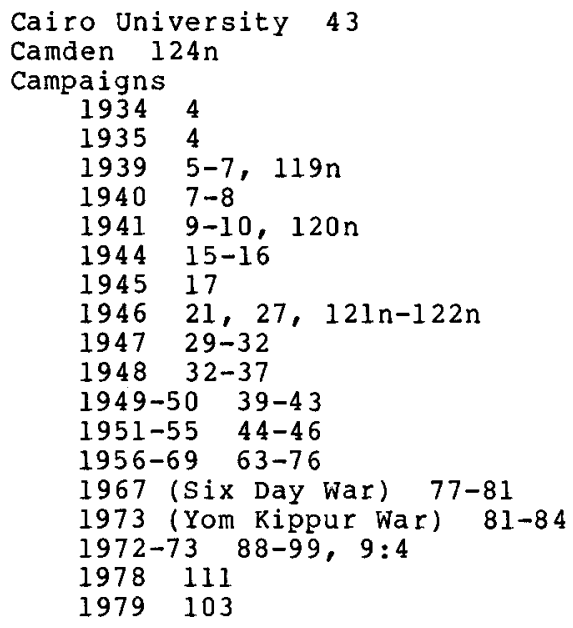




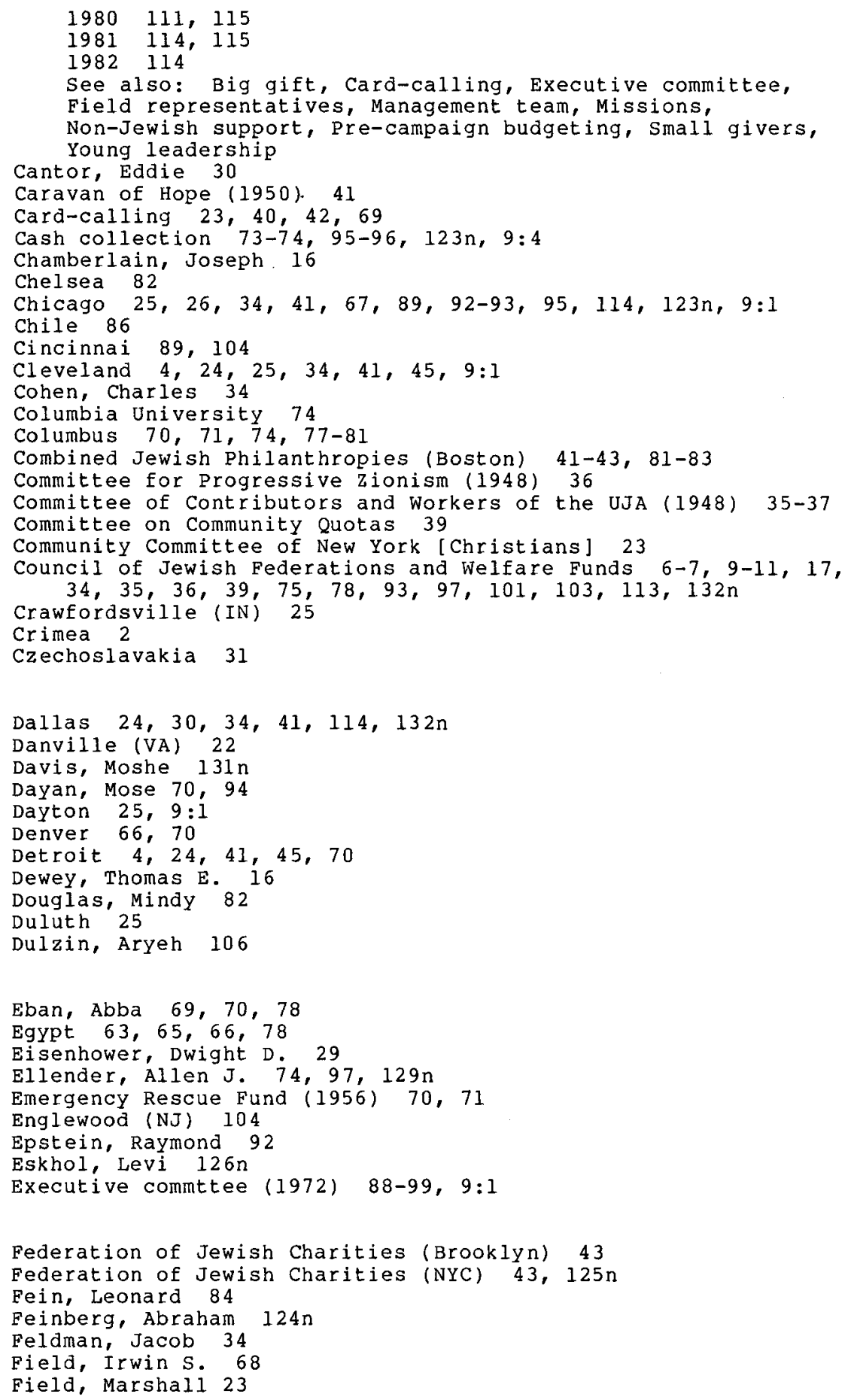




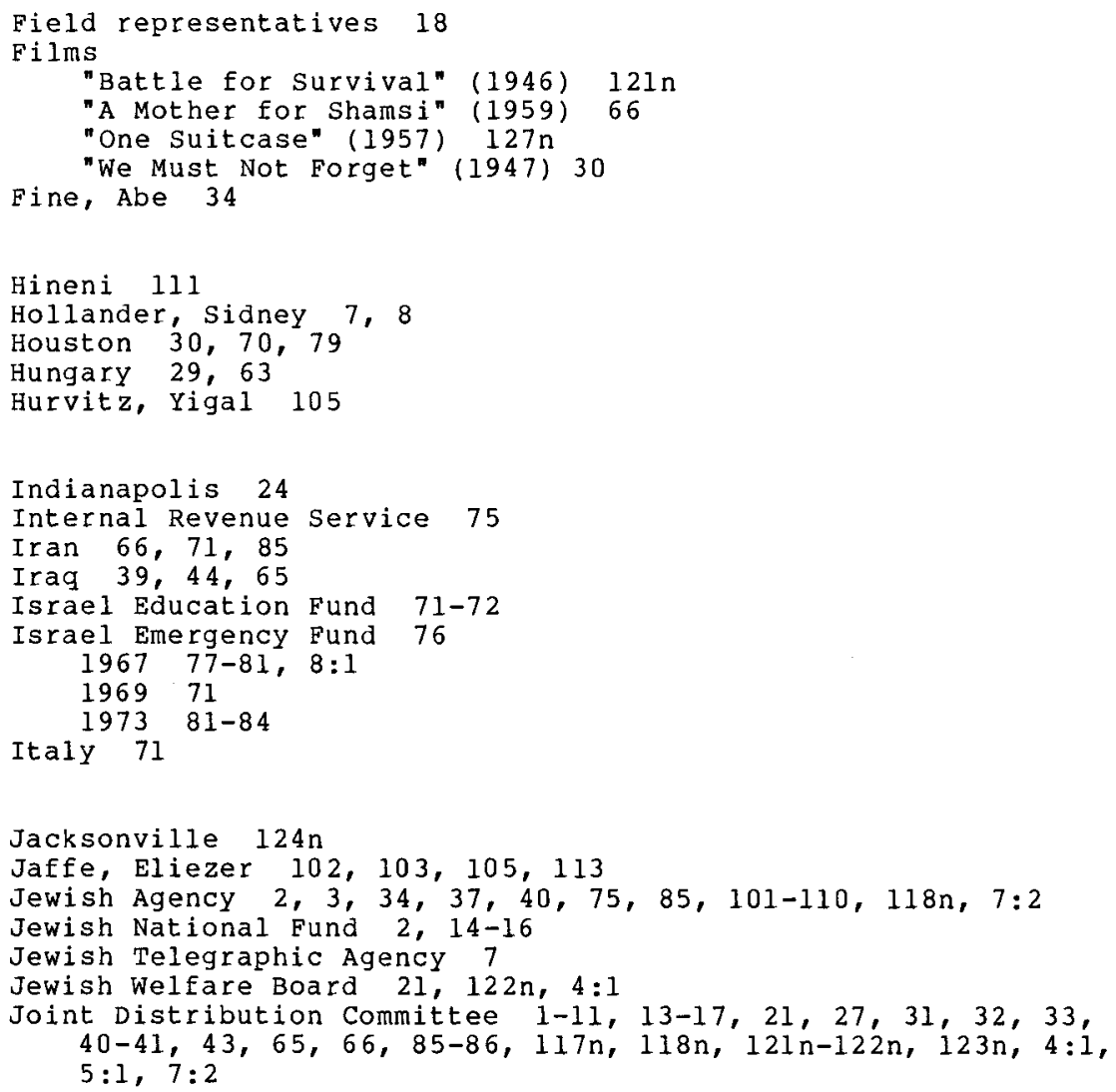


Management team 86-99

Markfield, Wallace 47 story by $48-61$

Markson, Y. D. 34

Medford 82

Meir, Golda 33-34, 70, 124n

Memphis 25

Miami $24,25,44,45,70$

Millikin, Roger $129 n$

Milwaukee $66,70,9: 1$

Missions $34,41,67,70-71,74,90-91,93,102,103,114-115$

Mizrachi 2

Monoson, Fred $124 \mathrm{n}$

Montor, Henry 9, 17-19, 22-27, 32-37, 39-43, 69, 72, 118n, $121 \mathrm{n}, 125 \mathrm{n}, 126 \mathrm{n}$

Morgenthau, Henry Jr. 29-31, 33-34, 37, 123n-124n

Morocco $63,65,71,73,85,127 \mathrm{n}$

Nashville 104

National Coordinating Committee for Aid to Refugees $1,7,8,11$

National divisions, origins 25

National Inaugural Conferences 69,94

National Refugee Service $8,9-10,13,14-15,21,120 \mathrm{n}, 122 \mathrm{n}$, $4: 1$

Nesher, Aryeh 92-93, 94, 131n

Neumann, Emanuel $36-37$

Newark 45,67

New Haven 74,79

New Israel Fund 112-113, 11:1

New Orleans $30,89-90,9: 1$

New York Association for New Americans 86, $7: 2$

New York City 21, 23, 24, 25, 29, 31, 34, 43, 45, 70, 79, 90, $94,95,9: 1$

Night of Stars 4,16

Non-Jewish support $16-17,23-24,29-30$

Oklahoma City $123 \mathrm{n}$

Omaha 30

100 percent plan 69

Operation Bootstrap 90

operation Breakthrough 91-93

operation Freedom 93

Operation Israel 90-91, 94, 9:3

Operation Jet 95

Operation Magic Carpet 43

Operation Upgrade $90,93,94,9: 2$

ORT 7,85

Palestine Economic Corporation 37

Palestine Foundation Fund 2

Paris Conference on Reparations 29

Paterson (NJ) 30

Pensacola 23-24

Philadelphia 22, 24, 27, 45

Pittsburgh 70

Pittsfield 82

Poland 29, 31, 39, 64, 65

Portland (OR) 70

Pre-campaign budgeting $40,72-73$

Project Potential 88-90, 93 
Project Renewal 97, 101-110

Providence 34, 9:1

Rabbinic Advisory Council 68-69

Raphaeli, Eliezer 105

Ratner, Leonard 34

Richmond (VA) 30

Rochester 22

Rockefeller, John D. 23

Rockefeller, Nelson A. 23, 29

Romania 29, 31, 39, 63-64, 86

Roosevelt, Eleanor 17, 29

Roosevelt, Franklin D. 16-17

Rosenwald, Julius 22, 25, 29

Rosenwald, William 1, 45, 69, 74

Rothenberg, Morris 4

Russell, Robert 109

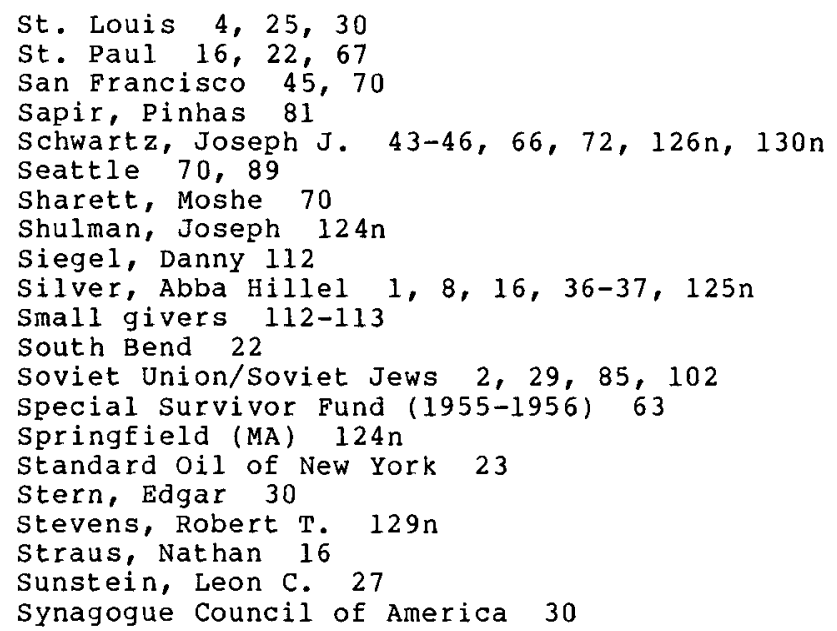


United Rayon 23

United Service for New Americans $29,31,32$

Warburg, Edward M. M. 45

Warburg, Felix M. 3, 22

Warburg, James 74-75, 97

Washington, D.C. 22, 70, 106, $9: 1$

Watson, Thomas J. 29

Weizmann, Chaim 3, 31-32

Wexner, Leslie $130 \mathrm{n}$

Whitney, John Hay 23

wilkes-Barre 30

Wise, Jonah B. 1,8

Wolkoff, H. K. 16

Women's struggle for equality 97-98

Woonsocket 25

Yadin, Yigael 105, 106, 133n

Yale University 43

Yankelewitz, Fred 83

Yemen 39, 43

York (PA) 24

Young leadership 67-68, 98, 114-115, 127n-128n

Zionist Organization of America 36-37 